\title{
AS PARCERIAS PÚBLICO-PRIVADAS DE METRÔ EM SÃO PAULO: as empresas estatais e o aprendizado institucional no financiamento da infraestrutura de serviços públicos no Brasil
}

\author{
Dissertação de Mestrado \\ Universidade de São Paulo \\ Faculdade de Direito \\ Departamento de Direito Econômico, Financeiro, Tributário e Ambiental
}

SÃO PAULO 


\title{
AS PARCERIAS PÚBLICO-PRIVADAS DE METRÔ EM SÃO
}

\section{PAULO: as empresas estatais e o aprendizado institucional no}

\section{financiamento da infraestrutura de serviços públicos no Brasil}

\begin{abstract}
Dissertação de mestrado apresentada ao Departamento de Direito Econômico, Financeiro, Tributário e Ambiental (DEF), da Faculdade de Direito da Universidade de São Paulo (USP), como requisito parcial para obtenção do título de Mestre em Direito, sob a orientação do Professor Associado Diogo Rosenthal Coutinho.
\end{abstract}

Candidato: Pedro do Carmo Baumgratz de Paula

Universidade de São Paulo

Faculdade de Direito

Departamento de Direito Econômico, Financeiro, Tributário e Ambiental

\section{SÃO PAULO}


Nome: DE PAULA, Pedro do Carmo Baumgratz

Título: As Parcerias Público-Privadas de metrô em São Paulo: as empresas estatais e o aprendizado institucional no financiamento da infraestrutura de serviços públicos no Brasil

Dissertação de mestrado apresentada ao Departamento de Direito Econômico, Financeiro, Tributário e Ambiental (DEF), da Faculdade de Direito da Universidade de São Paulo (USP), como requisito parcial para obtenção do título de Mestre em Direito, sob a orientação do Professor Associado Diogo Rosenthal Coutinho.

Aprovado em:

Banca Examinadora:

Prof::

Instituição:

Julgamento:

Assinatura:

Prof::

Instituição:

Julgamento:

Assinatura:

Prof:

Instituição:

Julgamento:

Assinatura: 
“(...) Sou mais um no Brasil da Central

Da minhoca de metal, que entorta as ruas

Da minhoca de metal, que entorta as ruas Como um Concorde apressado cheio de força

Voa, voa, pesado que o ar O avião, avião, avião do trabalhador (...)" "Rodo Cotidiano", O Rappa 


\section{AGRADECIMENTOS}

Essa dissertação de mestrado é o produto físico e acadêmico de uma jornada pessoal e imaterial única. Dessa jornada, levo algum aprendizado, mas, principalmente, levo as experiências que vivi e as pessoas com quem convivi. A elas serei eternamente grato.

Agradeço ao Professor Diogo Rosenthal Coutinho pela oportunidade oferecida, pelo ethos de competência e seriedade acadêmica que criou em seu grupo de orientandos, pela disponibilidade e atenção fornecidas ao longo de todo o processo, pelas diversas influências temáticas e metodológicas e, principalmente, por ter me instigado a investigar o direito no mundo real.

Agradeço ao grupo de pesquisa criado em torno do nosso orientador comum, Amanda Guazzelli, Charles Rossi, Flávia Annenberg, Flávia Chiquito, João Manuel, Jonas Antunes, Marcelo Pacheco, Nathalia Miziara, Paulo Casagrande, Raquel Pimenta, Ticiana Lima pelo espírito colaborativo e pelas críticas aos trabalhos discutidos em grupo. Nossa construção coletiva de conhecimento e abertura para criticar construtivamente uns aos outros redefiniu minha visão de como deve ser a discussão acadêmica.

Agradeço aos Professores Mario Gomes Schapiro e Vera Cristina Caspari Monteiro, pela excepcional banca de qualificação, que determinou os contornos de toda a dissertação e pela disponibilidade para me auxiliar em desdobramentos específicos da pesquisa em momentos posteriores.

Agradeço ao Professor Mario Engler Pinto Júnior, pelo enorme auxílio na busca dos verdadeiros problemas do caso estudado e pela ímpar disposição em criar oportunidades para o desenvolvimento da pesquisa empírica que, sem seu empenho pessoal, seria inviável.

Aos muitos amigos de disciplinas na pós-graduação, meu muito obrigado pelo companheirismo que me fez me apaixonar pela Faculdade do Largo de São Francisco.

Aos amigos que fizeram possível São Paulo se transformar, aos poucos, em minha casa - Diego Monnerat, Frederico Bastos, Marcelo Duarte, Marcelo Delgado, Mathias Pereira, Miguel De Vito -, vocês foram mais importantes do que podem imaginar. 
Aos amigos com quem tive o prazer de conviver por um ano e meio na FGV Adriane Sanctis, André Bergamaschi, Catarina Barbieri, Clarissa Gross, Eloísa Machado, Emerson Fabiani, Fábio Durço, Fernando Rocco, João Múcio, José Roberto Xavier, Karina Denari, Luciana Ramos, Maria Cecília Asperti, Maurício Chavenco, Nikolay Bispo, Osny Filho, Rubens Glezer, Thiago Mathias, Yonara de Oliveira e tantos outros que injustamente deixo de nomear -, agradeço por me mostrarem que o ensino e a pesquisa em direito, feitos com qualidade, podem, de fato, mudar o mundo e pelas amizades que levarei por toda a vida.

Devo um agradecimento especial a três amigos. Ao Rafael Zanatta e ao Flávio Prol, por terem lido e questionado cada ponto deste texto final, por terem se tornado grandes amigos e companheiros ao longo desses anos, por nossas discussões acadêmicas e por nossos compartilhamentos de angústias e de planos de vida, sou verdadeiramente grato. Ao Rafael Alem, amigo que me impulsionou a ingressar no mestrado e que, nos minutos prévios ao depósito, continuou a me auxiliar a identificar erros e a encontrar as melhores soluções para o texto, que esteve presente de uma ponta a outra nessa jornada, sou grato pela sincera amizade.

Aos meus pais, Vânia e Rogério, sou grato por muitas razões: por serem meus maiores exemplos profissionais e de vida, por se preocuparem a todo momento com meu bem-estar e com a viabilidade do alcance dos meus ideais, por compreenderem meu distanciamento e me acolherem sempre que precisei me reaproximar e por me instigarem a ser o melhor que posso a cada dia. À minha querida irmã, Laura, agradeço por me inspirar com sua competência e objetividade e por ter me propiciado a emoção de aguardar pelo nascimento de minha sobrinha, Maria.

Por fim, àquela que compreendeu a necessidade de vivermos fisicamente distanciados com a lucidez e que sempre esteve presente quando me questionei, me inspirando a ser forte como ela. A você, Sheyla, meu amor e minha eterna gratidão. 


\section{RESUMO}

A presente dissertação de mestrado consiste em um estudo de caso das contratações das parcerias público-privadas (PPPs) das Linhas 4 e 6 de metrô em São Paulo. A partir do estudo indutivo realizado, buscou-se compreender como os instrumentos jurídicos são efetivamente utilizados para viabilizar o provimento de uma atividade de interesse público para a população; a evolução institucional ocorrida no processo de aprendizagem de utilização dessas ferramentas; e o papel desempenhado pelas empresas estatais nesse novo cenário. Para tanto, o texto constrói a evolução das formas de concessão de serviços públicos e situa no plano histórico o surgimento e a adoção das PPPs como indicativos de uma nova forma de atuação estatal na economia. O estudo de caso foi elaborado a partir de análise documental e construção de narrativas, por entrevistas semiestruturadas, dos atores envolvidos nos processos de contratação das Linhas 4 e 6. A observação empírica revelou que as empresas estatais cumprem um papel fundamental na criação de arranjos institucionais funcionais para a viabilização dos empreendimentos conjuntos, exercendo uma função coordenação público-privada e promovendo aprendizado institucional. Também observou-se que complexos arranjos contratuais são utilizados como forma de separar as obrigações contratuais de demandas políticas, insulando os direitos do concessionário de alterações posteriores. Isso ficou evidente, especialmente, no tocante à diferenciação entre tarifa política e tarifa contratual, às garantias de pagamento de contraprestação e aporte e ao sistema de pagamentos de tarifas. Os resultados obtidos a longo dessa pesquisa acrescem ao conjunto de estudos que apontam para a inadequação de medidas institucionais de tamanho único para o desenvolvimento (teoria das "dotações institucionais"). A experiência indica que as PPPs estudadas foram bem-sucedidas justamente porque foram construídas a partir de soluções e arranjos institucionais específicos ao contexto em que estavam inseridas, levando em consideração as limitações e as potencialidades do direito local. Desse modo, a pesquisa conclui pela existência de um "modelo brasileiro" de PPPs que envolve, necessariamente, intermediação de empresas estatais na construção de arranjos institucionais cooperativos entre os atores públicos e privados.

Palavras-chave: "Parceria Público-Privada", "Transporte Público Urbano"; "Metrô"; "Empresas Estatais"; “Arranjos Institucionais"; "Direito Administrativo e Econômico". 


\begin{abstract}
This thesis is the written product of a case study of São Paulo's Metro Lines 4 and 6 public-private partnerships contracts. The objectives of this empirical study were to fully understand how: the legal tools are handled in order to provide a public service to the people; the institutional development in the process of learning the use of these tools; and the role played by state-owned enterprises in this new context. In order to do so, the text builds on the historical evolution of state concessions and the emergence of PPPs as indicators of a new way of State intervention in the economy. The case study was made using documental analysis and the building of narratives, through interviews with the main actors in the processes of contracting out the services of metro. The empirical observation revealed that state-owned enterprises play a significant role in the making of functional institutional arrangements necessary to the existence and function of joint enterprises, working as a coordinator of the public-private relationship and promoting institutional learning. Also, it was noted that complex contractual arrangements are used as a way of detaching contractual obligations from political demands, insulating concessionary's rights from ulterior changes. This was evidenced, specially, by the description of the contractual differentiation of tariffs (political vs contractual), also by the structure of the counterpart's warrantees, and by the payment system that was created. The results from this research add to the growing literature that points out the inadequacy of "one size fits all" institutional changes in order to promote development. The reported experience indicates that the PPP contracts were well succeeded precisely because they were built on context-specific solution and institutional arrangements, that took into account the limitations and potentialities of the local legal system. In this sense, the research shows the existence of a "Brazilian model" of PPP contracts that involves, necessarily, the intermediation of state-owned enterprises in the formation of cooperative institutional arrangements between public and private actors.
\end{abstract}

Key-words: "Public-Private Partnership"; "Urban Public Transportation"; "Metro"; "State-Owned Enterprises"; "Institutional Arrangements"; "Administrative and Economic Law". 


\section{LISTA DE ABREVIATURAS E SIGLAS}

BID - Banco Interamericano de Desenvolvimento

BIRD - Banco Internacional para Reconstrução e Desenvolvimento

BM - Banco Mundial

BNDES - Banco Nacional de Desenvolvimento Econômico e Social

CAPEX - Capital Expenditure [Investimentos de Capital]

CPP - Companhia Paulista de Parcerias

CPTM - Companhia Paulista de Trens Metropolitanos

Lei de PPP - Lei 11.079/2004

MetroSP - Companhia do Metropolitano de São Paulo

NAE - Novo Ativismo Estatal

PMI - Procedimento de Manifestação de Interesse

PNUD - Programa das Nações Unidas para o Desenvolvimento

PPP - Parceria Público-Privada

ROL - Rule of Law

Sabesp - Companhia de Saneamento Básico do Estado de São Paulo

STM - Secretaria de Transportes Metropolitanos do Estado de São Paulo

TIR - Taxa Interna de Retorno 


\section{ÍNDICE DE QUADROS}

Quadro 1 - Arranjo Contratual de Garantias via CPP 55

Quadro 2 - Modelo Tarifário e Sistema de Pagamentos 60

$\begin{array}{ll}\text { Quadro } 3 \text { - Sistema de Pagamentos SPTrans } & 62\end{array}$

Quadro 4 - O “colchão de demanda” 68

Quadro 5 - Sistema de Pagamentos SPTrans após a Linha $6 \quad 76$

Quadro 6-O "colchão de demanda” da Linha 6 82

Quadro 7 - Arranjo Contratual de Garantias das Contraprestações na Linha $6 \quad 83$

$\begin{array}{ll}\text { Quadro 8 - Pagamento de Aporte } & 91\end{array}$

Quadro 9 - Diferenças e Similitudes entre os contratos das Linhas 4 e $6 \quad$ 96-97 


\section{SUMÁRIO}

\section{INTRODUÇÃO}

1. Percurso metodológico: a construção empírica do conhecimento em direito e o estudo de caso

1.1 - Pesquisa em Direito e Políticas Públicas

1.2 - O problema de pesquisa

1.3 - Hipóteses de pesquisa 25

1.4 - Pesquisa qualitativa e indutiva

1.5 - Técnicas e procedimentos de pesquisa - por que um estudo de caso?

1.5.1 - Os documentos utilizados

2. PPPS: O APROFUNDAMENTO E A COMPLEXIFICAÇÃO DE UM MODELO

2.1 - Transporte público urbano e PPPs 37

2.1.1 - Transporte público urbano - histórico e desafios

2.1.2 - Antecedentes: Plano Nacional de Desestatizações, reforma do Estado e Lei de concessões

2.1.3 - As parcerias público-privadas - fundamentos e escolhas políticas 42

3. O ESTUDO DE CASO: ARRANJOS INSTITUCIONAIS E INSTRUMENTOS JURÍDICOS DAS LINHAS 4 E 6 DE METRÔ EM SÃO PAULO

3.1 - Linha 4 do metrô - o modelo de transição 48

3.1.1 - Diálogo público-privado 49

3.1.2 - As soluções contratuais 53

3.1.2.1 - Os mecanismos de garantia 53

3.1.2.2 - Diferenciação tarifária: separando o contrato da política 56

3.1.2.3 - O papel das estatais: sistema de pagamentos e o financiamento de projetos 
3.1.2.3.2 - Diferenciação tarifária, arrecadação conjunta e a questão da remuneração do concessionário na lei 11.079/2004

3.1.2.4 - Divisão adequada de riscos: a essência da noção de parceria? 66

3.1.3 - A influência da linha 4 nas contratações futuras 69

3.1.3.1 - Experimentalismo e Aprendizado Institucional 69

3.1.3.2 - Problemas na Execução: como evitar novos erros? 70

3.2 - Linha 6 - A afirmação do modelo 73

$\begin{array}{ll}3.2 .1 \text { - Características básicas } & 73\end{array}$

3.2.2 - Evolução institucional e a escolha de instrumentos jurídicos 74

$\begin{array}{ll}\text { 3.2.2.1 - O modelo tarifário } & 74\end{array}$

3.2.2.2 - Arrecadação conjunta e os limites do sistema de pagamentos como garantia $\begin{array}{ll}\text { institucional } & 75\end{array}$

$\begin{array}{ll}\text { 3.2.2.3 - Divisão objetiva de riscos } & 78\end{array}$

3.2.2.4 - A garantia por intermédio da CPP 82

3.2.2.5 - PPP integral: uma boa opção? 84

3.2.2.6 - Delegação da execução da desapropriação $\quad 87$

3.2.2.7 - Aporte financeiro: o ambiente institucional e os instrumentos contratuais 89

3.2.2.8 - PMI e diálogo institucional 91

3.3 - Discussão dos dados - lições e encaminhamentos de pesquisa 98

3.3.1 - Empresas estatais e a adoção do modelo de PPPs 98

3.3.2 - Limites e necessidades do modelo de financiamento público-privado 100

3.3.3 - Repercussões axiológicas das escolhas pelos instrumentos jurídicos - a questão da tarifa contratual $v s$ tarifa política

101

3.3.4 - O que falta ser compreendido?

102 
CONCLUSÃO

REFERÊNCIAS

ANEXO 1 - Roteiro de Entrevista

ANEXO 2 - Lista de Entrevistado

ANEXO 3 - Termo de Consentimento

117

ANEXO 4 - Lista de Documentos

ANEXO 5 - Cláusulas citadas do contrato da Linha 4

ANEXO 6 - Cláusulas citadas do contrato da Linha 6 
Aos meus pais, pelo apoio às minhas

decisões e por nossa - verdadeira e indispensável - amizade. 


\title{
INTRODUÇÃO
}

\begin{abstract}
"Mercados devem ser estudados sob o ângulo institucional, sociológico, histórico, como construções sociais. Tal abordagem evita um duplo equívoco. Por um lado, aquele que faz deles a solução universal, mágica, a todo e qualquer problema da coordenação humana em sociedades descentralizadas. (...) O segundo equívoco é simetricamente oposto ao primeiro: consiste na diabolização permanente do mercado (igualmente no singular) como expressão do egoísmo generalizado, de uma forma social que distorce a cooperação humana por definição. (...)

Esses dois extremos - o mercado enaltecido e o mercado demonizado

- tocam-se por lidarem com uma categoria abstrata e não com análises

históricas e empíricas. Eles são incapazes de enfrentar os desafios reais das inúmeras formas que assume a cooperação humana em uma sociedade

descentralizada. Uma das mais importantes tarefas das ciências sociais contemporâneas é estabelecer programas conjuntos de pesquisa que ultrapassem fronteiras disciplinares muitas vezes artificiais e que permitam compreender os mercados como produtos da interação social."
\end{abstract}

(ABRAMOVAY, 2004, p. 58-59)

O objetivo da pesquisa que resultou nessa dissertação de mestrado foi - a partir da análise dos procedimentos de contratação de parcerias público-privadas (PPPs) para as Linhas 4 e 6 do Metrô de São Paulo - compreender, empiricamente: como os instrumentos jurídicos são efetivamente utilizados para viabilizar o provimento de uma atividade de interesse público para a população; a evolução institucional ocorrida no processo de aprendizagem de utilização dessas ferramentas; e o papel desempenhado pelas empresas estatais nesse novo cenário.

O processo de desestatização iniciado na década de 1990 se restringiu à privatização de empresas estatais potencialmente superavitárias ${ }^{1}$ e à delegação de serviços públicos autossustentáveis. Havia uma barreira jurídica que o impedia de ir além: ausência de ferramentas jurídicas, capazes de garantir ao concessionário segurança de remuneração para além das receitas tarifárias.

“A lei das PPPs (isto é, a Lei Federal 11.079) teve, então, o limitado escopo de instituir justamente as regras faltantes." (SUNDFELD, 2011b, p.23)

\footnotetext{
${ }^{1}$ Isto é, aquelas cuja natureza da atividade não impõe que sejam deficitárias por razões de política social.
} 
Uma década se passou desde a edição das primeiras leis que instituíram e regulamentaram as parcerias público-privadas (PPPs) no Brasil. ${ }^{2}$ Ao longo desses mais de dez anos de produção acadêmica a respeito do tema, diversas questões sobre este instrumento jurídico e sua utilização na concessão de serviços públicos a prestadores privados mediante complementações financeiras estatais foram desenvolvidas e elaboradas, mas muitas dúvidas permanecem.

Quais as razões para a ampliação do modelo desestatizante? Como o direito evoluiu ao longo desses anos? Quais soluções foram encontradas? O que se trouxe da experiência das “concessões comuns" para as PPPs? Quais capacidades estatais foram desenvolvidas no primeiro momento [concessões comuns] e permitiram o avanço para o segundo [PPPs]? Quais consequências, para fins de interação público-privada e de intervenção estatal na ordem econômica, o novo arcabouço normativo e as novas realidades econômica e social trouxeram?

$\mathrm{Na}$ medida em que o direito é cada vez mais visto como grande instrumento mediador das mudanças institucionais e, por isso, do desenvolvimento social e econômico $^{3}$, as dúvidas acima levantadas precisam ser respondidas com base em dados reais, ou seja, no que efetivamente "é” e não apenas no que se supõe "dever ser". O conhecimento necessário para respondê-las depende, inevitavelmente, da descrição e da identificação de problemas empíricos e da compreensão de práticas igualmente concretas.

Muito embora a doutrina jurídica tenha vasta literatura sobre as características das PPPs sob os aspectos legal, comparado e histórico ${ }^{4}$, no Brasil ainda não há muitos estudos que busquem descrever e compreender, a partir de um estudo de caso, a

\footnotetext{
${ }^{2}$ Lei estadual n. 14.868 de 2003, de Minas Gerais. Lei estadual n. 11.688 de 2004 de São Paulo e lei federal n. 11.079 de 2004. Entre outras.

3 "Law is at the center of development discourse and practice today. The idea that the legal system is crucial for economic growth now forms part of the conventional wisdom in development theory. This idea's most common expression is the "rule of law" (ROL): a legal order consisting of predictable, enforceable and efficient rules required for a market economy to flourish." (SANTOS, 2006, p. 253)

${ }^{4}$ Sundfeld (2011a); Marques Neto e Schirato (2011); Ribeiro e Prado (2010); Aragão (2008); Alvarenga (2005); Meyer e Enei (2004); Monteiro (2009); Ribeiro (2011), entre outros.
} 
efetiva celebração das concessões patrocinadas ${ }^{5}$ sob a perspectiva do direito em ação (law in action).

Mais além, não há estudos que aprofundem, empiricamente, a compreensão das ferramentas jurídicas previstas nas leis quando postas em prática ${ }^{6}$ e em pleno funcionamento em setores específicos, como no de transportes públicos urbanos. Quando muito, os estudos mencionam a título de exemplos os contratos ou limitamse à avaliação de decisões judiciais, o que restringe a análise aos defeitos decorrentes da utilização das ferramentas e não consegue abarcar sua elaboração e seu efetivo funcionamento.

Igualmente, não se questiona como e se a adoção tout court de estruturas jurídicas internacionais se adequa às necessidades específicas da realidade brasileira e quais alternativas institucionais foram utilizadas para solucionar eventuais obstáculos. ${ }^{7}$

Ainda, a análise dogmática e isolada tem ignorado um importante fator: a relação dos parceiros privados com as empresas estatais que prestavam ou continuarão a prestar os serviços objeto de concessão.

Este trabalho almeja justamente suprir algumas dessas lacunas. A partir de uma descrição dos instrumentos jurídicos utilizados nos casos das linhas 4 e 6 do Metrô de São Paulo, busca-se compreender a prática jurídica brasileira atinente às concessões patrocinadas, em especial, no setor transporte público urbano metroviário, mas com repercussões para todos serviços públicos. Também pretende-se, com base nessa experiência, entender como as empresas estatais se encaixam nessa nova e mais complexa configuração de interação público-privada na ordem econômica.

Dessa forma, as principais variáveis de análise da evolução institucional ao longo dos anos são: o papel das empresas estatais na implementação desse novo

\footnotetext{
${ }^{5}$ A lei de PPPs trouxe duas novas modalidades de concessão, patrocinada e administrativa. Por ter como objeto a prestação de serviços públicos à população, as pretensões dessa pesquisa restringem-se à primeira.

${ }^{6}$ Uma importante ressalva é o livro do professor Maurício Portugal Ribeiro (RIBEIRO, 2011) intitulado "Concessões e PPPs: melhores práticas em licitações e contratos". Contudo, conforme se verá adiante, não se identifica com os propósitos dessa pesquisa, trata-se de um ótimo guia de melhores práticas para elaboração de editais e contratos com base na experiência profissional do autor e em textos acadêmicos, mas não consiste em um "estudo de caso" com foco na negociação de determinados contratos e no seu efetivo funcionamento.

${ }^{7}$ Inúmeros textos jurídicos questionam a adoção deste modelo "mais flexível" de contratação administrativa sob o ponto de vista político-ideológico, mas - via de regra - o fazem por uma abordagem dogmática, sem enfrentar em casos concretos os eventuais méritos e vícios do modelo; por todos Bandeira de Mello (2012).
} 
modelo de prestação de serviços públicos, as diversas formas de financiamento das obras e dos serviços, os arranjos institucionais construídos para garantir o pagamentos de valores ao parceiro privado e as formas de interação e a forma de realização do diálogo público-privado na construção do desenho institucional dos projetos.

Em síntese, poder-se-ia dizer que o que se faz aqui nada mais é do que contar uma breve história - com foco em dois contratos e inserida num contexto histórico de aprofundamento e de complexificação de um modelo de atuação estatal na economia - para dela poder tirar algumas conclusões e quiçá previsões.

Além dessa introdução, a dissertação conta com mais quatro capítulos.

No capítulo seguinte são esclarecidas as perspectivas epistemológicas, os conceitos e as teorias que fundamentam a construção do problema de pesquisa, as perguntas centrais do estudo e as hipóteses, os métodos e as técnicas utilizados para respondê-las.

O terceiro capítulo consiste em uma contextualização do histórico recente de desestatização de serviços públicos no Brasil. Nele se aborda a emergência do modelo de concessões da década de 1990 e sua evolução para o modelo de PPPs. Todo esse histórico é construído com fundamento nas teorias de economia política que estão por trás desses modelos de atuação do Estado na economia.

Após tal contextualização, é possível ingressar no efetivo estudo de caso. Portanto, no capítulo quatro são descritos e discutidos os principais tópicos referentes às contratações das PPPs das Linhas 4 e 6 de metrô em São Paulo. Nesse mesmo capítulo, realiza-se uma análise das implicações e das especificidades do modelo de PPPs brasileiro e de como o direito nacional impacta na construção de arranjos específicos.

Por fim, a conclusão busca retomar os principais achados e análises realizados ao longo do trabalho, confrontando as premissas teóricas às observações empíricas construídas no estudo de caso. 


\title{
CAPÍTULO 1 - PERCURSO METODOLÓGICO: A CONSTRUÇÃO EMPÍRICA DO CONHECIMENTO EM DIREITO E O ESTUDO DE CASO
}

\author{
"Não é, portanto, surpreendente constatar que o pesquisador qualitativo \\ esteja geralmente perdido, tentando caracterizar de maneira global a \\ abordagem à qual ele próprio aderia. Vítima da rapidez com a qual as \\ coisas evoluem, ou da miopia provocada por sua própria investidura \\ epistemológica e disciplinar, e, ainda, instalado numa posição defensiva \\ quanto aos preconceitos positivistas, ele transmitiu, em inúmeras ocasiões, \\ uma caracterização parcial da pesquisa qualitativa em seu conjunto.”
}

(PIRES, 2010a, p. 87)

Ao iniciar uma pesquisa científica o pesquisador comumente é perguntado e se defronta com questões epistemológicas e metodológicas. Por essa razão, esse capítulo da dissertação está estruturado na forma de respostas a perguntas e a tópicos diretos e, muitas vezes, não facilmente equacionáveis.

A postura adotada aqui não é de esclarecer estruturada e exaustivamente todos os pontos teóricos, mas sim de mostrar qual a posição do pesquisador quanto às questões epistemológicas, metodológicas e terminológicas essenciais à compreensão do trabalho.

Acredita-se que, assim, deixando claros os pontos de partida, as perspectivas ideológicas, o problema de pesquisa, as hipóteses, as teorias e os conceitos adotados, entre outros aspectos, o leitor estará mais próximo de ter em mãos um conhecimento verificável e potencialmente testável no mundo, ainda que consista em uma realidade e uma "verdade" parciais.

Para tanto, parte-se de questões gerais, ligadas à pesquisa em direito, e seguese em direção a tópicos mais específicos e técnicos, para poder introduzir os problemas concretos dessa pesquisa, os métodos e procedimentos utilizados para realizá-la e as influências teóricas que levaram ao desenho da pesquisa como aqui se encontra. 


\section{1 - Pesquisa em Direito e Políticas Públicas}

A noção de pesquisa, como aponta Coutinho (2011), não é unívoca. Há diversos tipos de pesquisa em direito, podendo ser dogmática, filosófica, comparada, em políticas públicas ${ }^{8}$, entre tantas outras.

Em especial, quando se trata de pesquisa atinente às políticas públicas, a importância do efetivo papel de cientista do pesquisador em direito, para além do tradicional papel de jurista ${ }^{9}$, fica ressaltada. Nesse aspecto, explica Coutinho (2012):

O debate público e as pesquisas acadêmicas em torno de aspectos formais e interpretativos são fundamentais para a formação dos juristas, não há dúvida. Mas dado que juristas brasileiros têm grande influência no modo como políticas públicas são moldadas, ajustadas e implementadas (na qualidade de legisladores, juízes e burocratas, respectivamente), é preciso reconhecer que são igualmente importantes as habilidades que lhes permitam conhecêlas em suas peculiaridades setoriais e meandros, beneficiando-se do aprendizado que o fato de fazê-lo sistematicamente lhes traria. Em especial, refiro-me a conhecimentos que permitam aos juristas, como práticos ou como acadêmicos, formular e propor soluções e ajustes que contribuem para executar ou mesmo aperfeiçoar tais políticas, mitigando suas disfunções e aumentando sua efetividade. (p. 5)

Essa discussão parte da premissa de que - conforme diversos estudos apontam $^{10}$ - as instituições têm um papel central no desenvolvimento econômico e social dos países. Logo, ao trazer as instituições para o centro do debate de desenvolvimento, o direito assume igualmente uma posição de destaque ${ }^{11}$.

\footnotetext{
${ }^{8}$ A relevância da pesquisa empírica e sua ligação com as políticas públicas são apontadas como fatores para a recente transformação da literatura jurídica nacional, de quase exclusivamente dogmática, para passar a abarcar também estudos científicos, conforme expõem Salama e Pargendler (2013). Para esses autores, a proeminência das políticas públicas foi um dos fatores que transformou o papel dos juristas: "A política pública propõe ao jurista o desafio de integrar meios jurídicos e fins normativos, e é neste momento que o saber jurídico tradicional se mostra insuficiente." (p. 112)

${ }^{9}$ Essa visão, a que se refere como "tradicional", é assim descrita por Lopes (2011): "O direito não é um saber a respeito do mundo como ele é, casualmente, mecanicamente, biologicamente. É um saber a respeito das normas capazes de determinar o que se deve fazer. Um bom jurista não explica para uma pessoa, no caso de uma separação, o quanto ela vai sofrer. Um bom jurista explica as alternativas de tomada de decisão jurídica." (p. 7)

${ }^{10}$ North (1994), Rodrik et al (2002), Santos (2006), entre outros.

${ }^{11}$ Instituições e direito posto não se confundem, embora, de acordo com North (2007): "Institutions are the rules of the game in a society or, more formally, are the humanly devised constraints that shape human interaction. In consequence they structure incentives in human exchange, whether political, social, or economic. Institutional change shapes the way societies evolve through time and hence is the key to understanding historical change." (p. 3)
} 
Entender quais estruturas jurídicas são capazes de auxiliar o desenvolvimento econômico passou a ser, a partir do ressurgimento das teorias institucionalistas ${ }^{12}$, o caminho para enxergar formas de reduzir custos de transação e permitir a emergência de mercados eficientes.

De acordo com Santos (2006), o direito passou a ser elemento central das reformas desenvolvimentistas ocorridas a partir dos anos 1980 e 1990 por organismos internacionais, como o Banco Mundial. Essas reformas pretendiam fornecer a "infraestrutura institucional" supostamente capaz de promover a transição para sociedades de mercado economicamente desenvolvidas e se pautava na ideia de implementação de "dotações institucionais"13.

No entanto, a tão propalada visão de North sobre as instituições não dá conta da importância da interação social na conformação das relações econômicas, como aponta Abramovay (2004, p. 52): "Há uma curiosa ambigüidade no trabalho de Douglass North, importante para a relação entre economia e sociologia no estudo dos mercados e das instituições. Por um lado, ele insiste na idéia de que os ambientes institucionais são decisivos para explicar a formação dos quadros de referência em que se apóiam os atores e as instituições que os moldam. (...) Quando, entretanto, procura explicar teoricamente a maneira como se formam as instituições, North volta-se muito menos para a história e para a interação social concreta do que para as ciências da cognição."

Dando continuidade à análise das críticas à visão cognitiva da formação das instituições, Abramovay (2004, p. 57) aponta que: "O importante no trabalho de Di Maggio é sua insistência na idéia de que os modelos mentais dos atores não devem ser buscados, contrariamente ao que propõe North, nas ciências da cognição, e sim na cultura, isto é, na sociologia e na antropologia cultural. Daí decorre uma visão das instituições em que a sociologia econômica marca também certa distância com relação à economia institucional: as instituições não são apenas 'restrições formais e informais que especificam a estrutura dos incentivos [...] elas envolvem atores, sejam eles indivíduos ou organizações, que perseguem interesses reais em estruturas institucionais concretas' (Nee, 2003). Swedberg (2003, p. xii) vai na mesma direção: 'as instituições, sob essa perspectiva, não devem ser entendidas como regras (que é a definição popular hoje), mas como configurações distintas de interesses e relações sociais'. A idéia é mostrar as instituições não como premissas, mas, antes de tudo, como resultados da interação social." Portanto, a visão das instituições como resultado da interação social, como destacada por Abramovay (2004), está por trás da análise institucional e histórica realizada nessa pesquisa.

${ }^{12}$ Para um histórico das teorias institucionalistas, ver Hodgson (2006).

${ }^{13}$ Como bem destacado por Schapiro (2009): "De fato, ao longo dos 90, acadêmicos e formuladores de políticas públicas enredaram-se no pressuposto de que os caminhos estavam trilhados e o estoque de soluções existentes, para os problemas sociais e econômicos, havia sido constituído. Era quase inexorável que o progresso econômico e o alívio da pobreza tivessem de contar com os atributos institucionais "corretos", tais como: a defesa da propriedade, a reforma do Estado, o impulso dos mercados, enfim, a garantia do "rule of law". Vem desta chave de análises, voltadas a realizar estudos de comparação entre os países, a pretensão de hierarquizar os seus fatores institucionais, assumindo como parâmetro um suposto funcionamento adequado de mercados e sociedades. A régua destes estudos dirige-se, assim, a medir o êxito dos países em realizar o seu programa de desenvolvimento, ancorada na idéia subjacente de uma democracia liberal, marcada pelas transações econômicas privadas. Não raro, partidários destas leituras costumam identificar as diferenças institucionais como deficiências e as alternativas, como equívocos.” (p. 306) No entanto, como relatado por Santos (2006) e Trubek (2006), essa visão unívoca de reforma institucional e de "rule of law" fracassou em alcançar os resultados esperados. Os estudos de Sabel (2004), Schapiro (2009), Rodrik (2007), entre outros, mostram como alternativas institucionais para o desenvolvimento devem ser desenhadas a partir da experiência e do aprendizado promovido nos ambientes objeto de transformação, contextualmente. 
Contudo, como destacam Rodrik et al. (2002), afirmar que as instituições importam para o desenvolvimento quer dizer muito pouco para alcançar soluções a problemas específicos, indicando a impossibilidade de reformas "de tamanho único" 14 e que seus estudos precisam de continuidade e desenvolvimento de pesquisas específicas. ${ }^{15}$

Tendo em conta essas limitações, Davis e Trebilcock (2008) ${ }^{16}$ e Prado (2010), chegam a conclusões semelhantes, quais sejam: o direito é detentor de um evidente potencial de promoção do desenvolvimento; esse potencial pode ser aproveitado de formas distintas em diferentes países e em diversos aspectos; e, por fim, essa multiplicidade de contextos faz necessário que - superado o debate sobre "se" o direito importa - se ingresse a fundo em "como" fazer com que ele gere resultados positivos.

Nesse ponto, assumem grande importância as noções de aprendizado e de experimentalismo institucional conforme expostas por Unger (1987; 1999, apud Zanatta, 2014), Unger e Lothian (2011), Sabel (2004) e Sabel e Reddy (2007). Em uma detida análise sobre o tema, Zanatta ${ }^{17}(2014)$, sintetiza a utilidade e a adequação da conjugação dessas teorias para o presente trabalho nos seguintes termos:

\footnotetext{
${ }^{14}$ Prado (2010) enumera os fatores limitadores desse tipo de reforma (one size fits all): dificuldade de delineamento do conceito de "instituições", empecilhos à implementação de mudanças institucionais e variantes culturais.

15 "How much guidance do our results provide the policy-makers who want to improve the performance of their economies? Not much at all. Sure, it is helpful to know that geography is not destiny, or that focusing on increasing the economy's links with world markets is unlikely to yield convergence. But the operational guidance that our central result on the primacy of institutional quality yields is extremely meager (...) There is growing evidence that desirable institutional arrangements have a large element of context specificity, arising from differences in historical trajectories, geography, political economy, or other initial conditions... This could help explain why successful developing countries-China, South Korea, and Taiwan among others-have almost always combined unorthodox elements with orthodox policies. It could also account for why important institutional differences persist among the advanced countries of North America, Western Europe and Japan-the role of the public sector, the nature of the legal systems, corporate governance, financial markets, labor markets, and social insurance mechanisms among others (...) Consequently, there is much to be learned about what improving institutional quality means on the ground. This, we would like to suggest, is a wide open area of research. Cross-national studies are at present just a beginning that point us in the right direction." (RODRIK et al, 2002, p. 21-23).

${ }^{16} \mathrm{O}$ histórico das escolas de direito e desenvolvimento pode ser encontrado no estudo de Davis e Trebilcock (2008).

${ }^{17}$ Zanatta (2014) chega a essas duas lições a partir de detida resenha literária sobre as obras de Unger e Sabel e suas análises a respeito dos mencionados autores são trazidas aqui como forma de analisar simplificada e diretamente as influências teóricas da pesquisa. Sobre Unger, Zanatta (2014) esclarece: "A prática da análise jurídica como imaginação institucional possui dois momentos dialeticamente ligados: o mapeamento e a crítica. Segundo Unger, o mapeamento (mapping) é a tentativa de descrever em detalhes a 'microestrutura institucional juridicamente definida' da sociedade em relação
} 
Os estudos de Unger e Sabel, enfim, oferecem duas lições aos juristas. A primeira é que o "experimentalismo democrático" necessita de novas formas jurídicas que permitam a reorganização de formas descentralizadas de governo e da economia em uma perspectiva horizontal (o processo de experimentalismo institucional envolve redefinição dos arranjos jurídicos e reorganização das formas jurídicas). A segunda é que uma alternativa "não dirigista" ao neoliberalismo e ao planejamento socialista envolve a construção de políticas públicas em uma perspectiva colaborativa - de interatividade permanente entre governo e sociedade -, fazendo com que o direito administrativo estimule o compartilhamento de aprendizado entre diferentes atores e utilize tal aprendizado para redefinir os arranjos institucionais que moldam a própria política colaborativa. Tal processo de compartilhamento e aprendizado para execução de políticas deve permitir a participação dos interessados, garantindo a legitimidade democrática da abordagem experimentalista. (p. 74-75)

Por essas razões, essa pesquisa é realizada com base nas premissas de que as instituições de fato importam para o desenvolvimento, mas que sua definição é específica a contextos institucionais, históricos e culturais e que, por isso, a compreensão empírica de realidades distintas é essencial ao estudo do direito.

\footnotetext{
a seus ideais juridicamente 'articulados. A crítica (criticism) é a tarefa de explorar a inter-relação entre os arranjos institucionais detalhados da sociedade, tal como representado no direito, e os 'ideais professados ou programas' que esses arranjos frustram ou tornam real. (...)De acordo com método de análise jurídica proposto por Unger, a primeira tarefa que o jurista deve propor a si próprio é a de entender as situações institucionais existentes como estruturas complexas e contraditórias, afastando-se das abstrações como 'economia mista', 'democracia representativa' ou 'sociedade industrial'. Entretanto, ao elaborar tal cenário a partir da análise dos materiais jurídicos disponíveis, o jurista não deve buscar uma 'reconstrução racional' que justifique e interprete a estrutura existente como expressão de um sistema em evolução de concepções morais e políticas.” (p. 49-50) A respeito da construção teórica de Sabel sobre aprendizado institucional e sua crítica à ideia das "dotações institucionais", Zanatta (2014) pontua: "A ideia de bootstrapping está ligada à capacidade de 'lançar-se de forma autônoma', sem auxílios externos. Reposicionando tal conceito nos debates sobre reforma institucional e desenvolvimento, Charles Sabel utiliza-o para combater a perspectiva das 'dotações institucionais', isto é, a ideia de que alguns países possuem arranjos institucionais que geram incentivos adequados para agentes econômicos em uma economia de mercado - tal como presente na influente tese das 'origens jurídicas' de autores da corrente Law and Finance. Sabel, enfim, opõe-se à ideia de que deve haver uma convergência jurídico-institucional aos moldes das prescrições liberalizantes do 'Consenso de Washington'.

Para o autor, estimular o 'contínuo aprendizado social' é uma tarefa central do Estado. Em uma visão boostrapping, o objetivo é criar instituições que possam aprender a identificar e mitigar diferentes restrições ao crescimento, 'incluindo as que surgem de defeitos na organização presente nas próprias instituições de aprendizado'. As restrições, nessa visão, não são apenas obstáculos às transações de mercado (insegurança jurídica, problemas no enforcement de direitos de propriedade e tributação). São restrições à capacidade de colaboração público-privada de incentivo à atividade econômica.

Para Sabel, as intervenções institucionais objetivam moldar o comportamento empreendedor, em um processo de colaboração que reconhece as limitações cognitivas tanto do setor público quanto do privado. (...)" (p. 65)
} 
Portanto, na perspectiva aqui adotada, a pesquisa em direito é sim capaz de ser geradora de conhecimento e ser tida como "ciência", desde que observados critérios de objetividade analítica e de validade metodológica. Mais além, não só é viável realizar pesquisa científica e empírica em direito como ela é essencial para "desatar os nós do desenvolvimento" 18 e, com isso, promover avanços sociais típicos do conhecimento científico.

\section{2 - O problema de pesquisa}

A definição de um problema é a base da pesquisa científica, pois é na tentativa de respondê-lo que se poderá produzir conhecimento, testar hipóteses, descrever cenários, históricos e situações, etc. Igualmente, é a partir da definição do problema de pesquisa (que pode ser composto ou delineado por diversas perguntas) que as demais escolhas metodológicas serão feitas, a saber: o tipo de pesquisa, a forma de produção de conhecimento, os procedimentos de coleta de dados, o referencial teórico adotado, entre outros aspectos.

Embora a trajetória de formação do problema dessa pesquisa o tenha transformado completamente ${ }^{19}$, como sói acontecer em pesquisas qualitativas, acredita-se que a apresentação direta das perguntas que foram definidas como as determinantes do trabalho abrirá o caminho para narrar a construção da pesquisa e os demais temas metodológicos e conceituais necessários para sua melhor compreensão.

Dessa forma, considerando os procedimentos de contratação das concessões patrocinadas das linhas 4 e 6 de Metrô em São Paulo ${ }^{20}$, questiona-se:

Como o uso dos instrumentos jurídicos existentes no Brasil e o ambiente institucional em que os contratantes estavam inseridos foram orquestrados para a celebração dos contratos?

\footnotetext{
${ }^{18} \mathrm{Na}$ expressão de Sabel e Reddy (2007).

${ }^{19}$ Como bem lembram Raymond Quivy e Luc Van Campenhoudt (2008), a definição do problema não é algo linear e de fácil obtenção: "No início de uma investigação ou de um trabalho, o cenário é quase sempre idêntico. Sabemos vagamente que queremos estudar tal ou tal problema (...), mas não sabemos muito bem como abordar a questão. Desejamos que este trabalho seja útil e resulte em proposições concretas, mas temos a sensação de nos perdermos nele ainda antes de o termos realmente começado. Este caos original não deve ser motivo de inquietação; pelo contrário, é a marca de um espírito que não se alimenta de simplismos e de certezas estabelecidas.” (p. 20-21)

${ }^{20}$ Que serão narrados ao longo de todo o trabalho.
} 
- Quais desafios foram encontrados no diálogo entre os atores público e privados na elaboração dos editais e na celebração dos contratos?

- Quais soluções foram adotadas?

- Como os instrumentos jurídicos ${ }^{21}$ foram utilizados na construção dessas soluções?

Como a Companhia do Metropolitano de São Paulo (MetroSP) e demais estatais envolvidas atuaram nesses processos?

- Qual o papel das estatais nesse contexto?

- Que desafios e soluções foram encontrados para a convivência de estatais e concessionárias operando na mesma rede de transportes públicos?

Em que medida, a experiência das Linhas 4 e 6 indica a existência de um modelo institucional brasileiro de adoção de PPPs, em oposição a desenhos institucionais transplantados de experiências estrangeiras?

Quais as diferenças entre os arranjos institucionais da linha 4 e da linha 6 ?

- Há indícios de alterações possibilitadas por aprendizado institucional?

\section{3 - Hipóteses de pesquisa}

A pesquisa realizada possuiu, em grande parte, objetivos descritivos que não comportavam a elaboração de hipóteses precisas. As perguntas com base na palavra "como" já indicam a centralidade dos objetivos de descrição e indução puras atribuídos ao estudo de caso. Contudo, alguns aspectos das perguntas levantadas puderam ser objeto de elaboração de hipóteses.

\footnotetext{
21 “ $O$ estudo das diferentes possibilidades de modelagem jurídica de políticas públicas, a escolha dos instrumentos de direito administrativo mais adequados (dados os fins a serem perseguidos), o desenho de mecanismos de indução ou recompensa para certos comportamentos, o desenho de sanções, a seleção do tipo de norma a ser utilizada (mais ou menos flexível, mais ou menos estável, mais ou menos genérica) são exemplos de tópicos que surgem quando o direito é instrumentalizado para pôr dada estratégia de ação em marcha." (COUTINHO, 2012, p. 21)
} 
Quanto aos dois primeiros grupos de questões, acredita-se que, no caso específico do Estado de São Paulo, a prévia existência da Companhia do Metropolitano e da CPTM (i.e. a inserção das PPPs das linhas 4 e 6 em um ambiente institucional que já continha atores estatais atuantes) viabilizou um arranjo contratual que gerou maior segurança jurídica no tocante ao fluxo de caixa (considerado a principal garantia em modelos de project finance).

Por isso, acredita-se que um ponto central na viabilidade das parceiras, tendo em vista as limitações impostas pelo precatório e a relevância financeira do recebimento das tarifas para a atividade, foi a existência de uma arrecadação conjunta, a preferência de recebimento da sua parcela que foi conferida às concessionárias das linhas 4 e 6 e o volume de fluxo de caixa gerado pela grande operação já existente da Companhia do Metropolitano e da CPTM.

Em síntese, a existência de atores estatais, cuja saúde financeira está resguardada pelo próprio Estado de São Paulo, facilitou o aumento do fluxo de caixa do sistema de transporte sobre trilhos, de forma a garantir que o total arrecadado mesmo considerando-se as gratuidades e deduções e a eventual diferença entre "tarifa contratual" e a "tarifa política" (paga pelo usuário para usar o sistema) - bastaria para cobrir a parcela das concessionárias sem necessidade de execução de garantias ou de dívidas pela via judicial.

Além disso, postula-se que a existência desses atores também se mostrou como importante mecanismo de transição do provimento do serviço de metrô por empresas estatais para o sistema de parcerias público privadas, já que a Companhia do Metropolitano conduziu o edital da linha 4 e ela e a CPTM ingressaram como intervenientes na celebração do contrato. Essas empresas forneceram know-how e capacidades institucionais $^{22}$ ao Estado de São Paulo nos aspectos técnicos de suas contratações. Já o edital da linha 6 foi conduzido pela própria Secretaria de Transportes Metropolitanos, o que indica que a linha 4 funcionou, de fato, como modelo de transição.

Acredita-se que a linha 4 funcionou como modelo de transição de prestação do serviço de metrô por empresas estatais para um modelo de parcerias que começa a

\footnotetext{
${ }^{22}$ Nos termos da definição proposta por Gomide e Pires (2014, p. 20), melhor desenvolvida no tópico 3.2.2.3 dessa dissertação.
} 
se afirmar com o contrato da linha 6, visando a manejar incentivos econômicos - por meio de ferramentas jurídicas - de forma a promover eficiência via aprendizado e evolução institucional ${ }^{23}$.

\section{4 - Pesquisa qualitativa e indutiva}

Dada a natureza do problema apresentado e dos objetivos que dele advêm, a pesquisa possuiu inevitavelmente natureza qualitativa, conforme definida por Pires (2010a):

Pode-se, então, provavelmente dizer que a pesquisa qualitativa se caracteriza, em geral: a) por sua flexibilidade de adaptação durante seu desenvolvimento, inclusive no que se refere à construção progressiva do próprio objeto da investigação; b) por sua capacidade de se ocupar de objetos complexos, como as instituições sociais, os grupos estáveis, ou ainda, de objetos ocultos, furtivos, difíceis de apreender ou perdidos no passado; c) por sua capacidade de englobar dados heterogêneos, ou, como sugerem Denzin e Lincoln (1994:2), de combinar diferentes técnicas de coleta dos dados; d) por sua capacidade de descrever em profundidade vários aspectos importantes da vida social concernentemente à cultura e à experiência vivida, justamente devido à sua capacidade de permitir ao pesquisador dar conta (de um modo ou de outro) do ponto de vista do interior, ou de baixo; e) finalmente, por sua abertura para o mundo empírico, a qual se expressa, geralmente, por uma valorização da exploração indutiva do campo de observação, bem como por sua abertura para a descoberta de 'fatos inconvenientes'(Weber), ou de 'casos negativos'. Ela tende a valorizar a criatividade e a solução de problemas teóricos propostos pelos inconvenientes. (p. 90-91. Destaques feitos pelo autor)

Acredita-se que esse tipo de pesquisa é o mais adequado aos problemas propostos, uma vez que são perguntas complexas, que envolvem diversos tipos de dados e que dependem essencialmente da perspectiva de quem se envolveu com os editais e contratos em análise.

\footnotetext{
${ }^{23}$ A ideia de "mudança de modelo" acima mencionada é embasada na crescente utilização de PPPs ao longo dos últimos anos (por todos PPPBRASIL, 2011) e nas declarações do vice-governador do Estado de São Paulo ao jornal "Valor Econômico", do dia 15/02/2013, afirmando que a linha 20 do metrô e a linha 18 bronze seguiriam o mesmo modelo adotado na linha 6, e que com a crescente presença de operadores de metrô o Estado de São Paulo pretende criar uma agência reguladora para verificar o cumprimento dos contratos.
} 
De igual modo, como o objetivo central é realizar uma descrição minuciosa e contextualizada do efetivo funcionamento dos contratos de PPP de metrô, uma pesquisa primordialmente quantitativa não seria a melhor opção, embora dados quantitativos sejam a todo momento utilizados como forma de auxiliar a análise qualitativa.

Ademais, o trabalho não visa a testar a veracidade de uma teoria ou de um conceito abstrato no mundo concreto, ao revés, tem objetivos descritivos de apreender a realidade a partir de um estudo de caso para, assim, poder extrair conceitos, teorias e previsões possivelmente generalizáveis ${ }^{24}$.

Desse modo, conclui-se ser a pesquisa realizada de natureza qualitativa e indutiva. (cf. QUIVY e CAMPENHOUDT, 2008)

\section{5 - Técnicas e procedimentos de pesquisa - Por que um estudo de caso?}

Como já mencionado anteriormente, o objetivo primordial desta pesquisa é fornecer uma descrição contextualizada da contratação de PPPs de metrô no Estado de São Paulo, para, assim, poder construir indutivamente os aspectos jurídicoinstitucionais das PPPs no Brasil.

Mais do que expor as alterações legais e apontar suas aplicações nas cláusulas contratuais, a pesquisa se propõe a apresentar a forma pela qual as ferramentas jurídicas foram utilizadas em um contexto de finalidades a que se prestam e de justificativas de suas escolhas pelos agentes envolvidos. Tem-se como meta descrever o "funcionamento" destes contratos.

Imaginando as relações sociais como um jogo de futebol e o regramento jurídico como as regras do jogo: para além de explicar as regras, busca-se narrar o

\footnotetext{
${ }^{24}$ Sobre o potencial de generalização, Pires (2010b): “(...) Do mesmo modo que se diz que cada pessoa é 'única', quando se aprecia nos detalhes, o pesquisador pode descobrir, após uma descrição em profundidade, que seu caso é único. (...) Nenhum vilarejo (town), pode, provavelmente, representar todos os outros (all of suburbia), e tampouco a falta de traço particulares passíveis de distingui-la dos outros lugares. No entanto, o estudo de um único vilarejo nos dá um meio acessível de reunir uma informação detalhada que pode lançar uma luz (offer insights) sobre uma grande variedade de conjuntos análogos. (BAUMGARTNER, 1988: 14).” (p. 193)
} 
jogo e, assim, explicar o efetivo funcionamento das regras, independentemente do "apito do juiz". 25

Essa abordagem não desmerece revisões de legislação, doutrina, estudos de jurisprudência e outras formas de estudo dos fenômenos jurídicos. Consiste apenas em um recorte que supõe haver mais para o direito do que o que é evidenciado na previsão estática dos textos legais e nas decisões judiciais ou arbitrais.

A "vida" de um contrato (e consequentemente de uma concessão) pode transcorrer inteiramente sem ser questionada judicialmente. Ao se analisar somente os pontos críticos e de conflito levados a litígio limita-se as pesquisas às patologias contratuais e se falha em obter uma descrição do fenômeno jurídico naquilo que foi inovador e bem sucedido.

Para alcançar os objetivos pretendidos, uma combinação de técnicas e métodos de pesquisa precisou ser posta em prática.

Primeiramente uma revisão de literatura sobre transporte público urbano, parcerias público-privadas, financiamento de projetos (project finance) e direito e desenvolvimento foi realizada, de modo a possibilitar a elaboração das perguntas acima expostas em meio a um quadro teórico-conceitual consistente. Essa revisão de literatura também serviu para demonstrar que a grande maioria dos estudos jurídicos nacionais sobre PPPs se limitam às visões históricas, comparadas, legais e jurisprudenciais, não havendo estudos de caso - jurídicos e detalhados - sobre PPPs em transporte público urbano. ${ }^{26}$

Superada essa fase, pode-se ingressar nos $\operatorname{casos}^{27}$. As linhas 4 e 6 do metrô, enquanto unidades de análise do estudo de caso proposto ${ }^{28}$, foram selecionadas por diversos motivos.

\footnotetext{
${ }^{25}$ Devo a analogia do funcionamento dos contratos em comparação com um jogo de futebol ao amigo Osny da Silva Filho que a desenvolve melhor em artigo ainda não publicado: Osny da Silva Filho e Rafael Barros de Oliveira, Kick-Off: Contract Law as Institutional Architecture (inédito).

${ }^{26}$ Alguns dos textos revisados foram, entre outros, Sundfeld (2011); Marques Neto e Schirato (2011); Ribeiro e Prado (2010); Aragão (2008); Alvarenga (2005); Meyer e Enei (2004); Monteiro (2009); Ribeiro (2011); Carmona (2010); Vasconcellos et al (2011); Bovis (2008); Brandão et al (2012); Enei (2005). Valente (2012), faz um breve estudo sobre direito e economia e indica, à título de exemplos, alguns contratos de metrô; no entanto, são apenas mencionados alguns problemas nos mesmos, não é realizado um efetivo estudo de caso sobre sua negociação, celebração e funcionamento.

${ }^{27}$ Sobre os estudos de caso, Pires (2010b) afirma que: “(...) Em um estudo de caso, não nos interessamos unicamente pelas especificidades do caso em questão (ainda que elas possam ser valorizadas e importantes), mas também por sua capacidade de servir de via de acesso a outros fenômenos ou a outros aspectos da realidade. (...)

Eis alguns critérios que influem na escolha do caso: a pertinência teórica (em relação aos objetivos iniciais da pesquisa); as características e a qualidade intrínseca do caso; a tipicidade ou a
} 
Primeiramente, a linha 4 foi a primeira PPP do Brasil após a edição da lei 11.079/2004, o que confere ao seu estudo grande potencial de evidenciar utilizações inovadoras dos instrumentos legais, bem como de mostrar o que deixou de ser usado e o que é aplicado diferentemente atualmente. Por ser a primeira experiência e não contar com casos nacionais prévios para se espelhar, a linha 4 também apresenta as características necessárias para avaliar o aspecto evolutivo da prestação e da desestatização dos serviços públicos deficitários no Brasil.

Já a linha 6 era, à época do exame de qualificação de mestrado, a mais recente experiência no Estado de São Paulo em contratação de transporte público urbano de que se pode extrair dados até o final da pesquisa ${ }^{29}$. Seu edital é fruto de um complexo processo de diálogo entre parceiros públicos e privados, via Procedimento de Manifestação de Interesse (PMI), o que pode gerar substantivo material para análise de interação e aprendizado institucional.

Além disso, a linha 4 e a linha 6 são duas importantes linhas de metrô subterrâneo, que cruzam o centro de São Paulo fazendo integrações com as linhas da CPTM e do MetroSP, sendo - portanto - comparáveis, em termos de objeto do contrato e de complexidade do diálogo institucional.

O estudo de caso envolve duas unidades de análise (dois procedimentos que culminaram na celebração de PPPs) para poder atingir o objetivo de realizar uma análise histórica da atuação estatal na ordem econômica. Não bastasse tal necessidade interna de continuidade, para fins de generalizações e eventuais previsões, também é importante compreender a trajetória e não só eventos isolados.

A partir da revisão de literatura, de entrevistas exploratórias e da análise de documentos do caso estudado, pode-se constatar que os principais parâmetros de análise evolutiva estariam ligados a quatro variáveis, quais sejam: o papel das empresas estatais na implementação desse novo modelo de prestação de serviços

exemplaridade; a possibilidade de aprender com o caso escolhido; seu interesse social; sua acessibilidade à investigação;" (p. 180;183)

${ }^{28}$ De acordo com Yin(2010), um estudo de caso pode ser composto por mais de uma unidade de análise. Nessas situações, o "caso" é a compreensão conjunta dessas unidades.

${ }^{29}$ Ao longo da pesquisa, foram lançados PMIs das linhas 18 e 20. No entanto, a publicação de um PMI não gera, necessariamente, a publicação de um edital e, ainda que este venha a ser publicado, o prazo de conclusão desta pesquisa (janeiro de 2015) é incompatível com o tempo geralmente levado para se publicar uma consulta pública e um edital de concorrência internacional. Portanto, se se objetivasse estudar estas - eventuais - linhas, correr-se-ia o risco de não ter prazo para avaliar os documentos essenciais para uma análise mais detida, nem de se realizar as necessárias entrevistas com os agentes envolvidos. Além disso, a linha 18 utilizará a tecnologia de monotrilho, o que a diferencia substancialmente das outras linhas aqui estudadas podendo gerar inviabilidade de comparação por questões técnicas de engenharia, como os ricos envolvidos e o custo de obra, entre outros fatores. 
públicos, as formas de financiamento das obras e dos serviços, os arranjos institucionais construídos para garantir o pagamentos de valores ao parceiro privado e as formas de interação e a forma de realização do diálogo público-privado na construção do desenho institucional dos projetos. Por isso, deu-se especial atenção às cláusulas contratuais e às colocações dos entrevistados que tratavam das variáveis de análise.

Esse estudo de caso, em ambas unidades de análise, combinou as técnicas de análise de conteúdo dos documentos centrais dos projetos e entrevistas semiestruturadas com atores envolvidos nos processos.

\subsection{1 - Os Documentos utilizados}

A análise de conteúdo teve como cerne a identificação e descrição dos mecanismos jurídicos utilizados pelas partes para viabilizar os empreendimentos, a justificativa dos atores envolvidos pela escolha dos instrumentos específicos e suas consequências jurídicas para as relações contratuais entre as partes.

Para tanto, utilizou-se não só os editais e contratos centrais do caso, mas também relatórios de investimento dos financiadores, exposições de motivo de diplomas legislativos, entre outros.

A lista completa dos documentos utilizados está no Anexo 4. Nela, também encontram-se as informações acerca da disponibilidade online ou não dos documentos e seu conteúdo mínimo.

Cabe aqui uma constatação a respeito dos documentos centrais do estudo.

Os documentos da linha 4 foram o edital de concorrência internacional $\mathrm{n}$. 42325212/2005 e o contrato de concessão patrocinada n. 4232521201/2006. Embora o edital fosse facilmente obtido na internet, o contrato assinado não foi encontrado por mecanismos de busca e foi obtido digitalizado por meio de agentes envolvidos no questionamento judicial de aplicação de multas administrativas à concessionária, tendo, portanto, se tornado público ${ }^{30}$.

Quanto aos documentos da linha 6, houve significativa evolução em termos de transparência da ação estatal. Desde o início do processo do PMI, todos os documentos do projeto estiveram disponíveis no site da STM, permitindo fiscalização e questionamento público. Sendo assim, o acesso aos documentos de cada fase do

\footnotetext{
${ }^{30}$ Documentos publicamente disponíveis nos autos do processo n. 0048023-95.2012.8.26.0053, que corre perante a $8^{\mathrm{a}}$ Vara da Fazenda Pública de São Paulo, SP.
} 
processo, inclusive questionamentos de consultas públicas, entre outros, é acessível a todos. Contudo, ainda que tenha sido disponibilizada a ata de julgamento das propostas da licitação, o contrato de concessão patrocinada 015/2013 (contrato da linha 6) assinado, não foi encontrado nos sites oficiais. Novamente, a judicialização do contrato o fez ficar disponível ao público em ação que questiona a realização da desapropriação pelo concessionário ${ }^{31}$.

\subsection{2 - As Entrevistas}

Também foram realizadas entrevistas semiestruturadas com atores relevantes nas duas contratações, como forma de obter informações sobre a justificativa da adoção de determinadas ferramentas jurídicas e de descrever com maior precisão os problemas e soluções das fases negociais da dos editais e dos contratos em análise ${ }^{32}$.

Mais além, as entrevistas serviram como forma de identificar os pontos críticos dos projetos. De forma descontextualizada, o pesquisador não possui mecanismos para identificar quais cláusulas foram as principais, quais problemas elas visavam a solucionar e qual foi a forma de sua construção. Os principais atores envolvidos nesse processo, selecionados de modo a compreender as diversas visões possíveis a respeito do caso, jogam luz sobre os pontos nodais, viabilizando uma análise descritiva focada naquilo que realmente importa.

Além de indicar os pontos centrais dos processos de contratação das PPPs estudadas, as entrevistas se prestam a fornecer as diferentes visões dos atores sobre esses processos. Por isso, optou-se por utilizar citações literais das falas dos

\footnotetext{
${ }^{31}$ Contrato disponível como anexo ao recurso de apelação nos autos do processo n. 102421828.2014.8.26.0053 que corre perante a $13^{\mathrm{a}}$ Vara da Fazenda Pública de São Paulo, SP.

${ }^{32}$ A relevância das informações extraídas por entrevista e sua capacidade de se transmudar em afirmações sobre o mundo são explicadas por Pires (2010b) da seguinte forma: "Convém distinguir, portanto, a partir de um ponto de vista metodológico, a certeza expressada pelo entrevistado da certeza que o analista tenta alcançar. Como há risco de erro nos dois casos, devem-se colocar duas dúvidas metódicas, que não se situam no mesmo momento da pesquisa, e que são relativamente diferentes. Primeiramente, a certeza do informante sobre um fato deve sempre ser vista como um forma de crença: não é porque ele está convencido de que as coisas se passam de uma certa maneira que elas efetivamente são assim. Quando um dos entrevistados diz que 'sabe' que as coisas aconteceram assim, isto significa, simplesmente, que ele está certo disso. Neste sentido, 'saber' não significa que é verdade, mas apenas que se está convencido disto (WITTGENSTEIN, 1958: 31-32). Mas depois é preciso também dosar essa dúvida, porque não se pode fazer pesquisa com base nos fatos, apenas duvidando. Efetivamente, deve-se, de um lado, estar atento, e mesmo desconfiado, em relação às representações, e, de outro lado, garantir certos conhecimentos, sob pena de renunciar à pesquisa de um 'conhecimento aproximado', segundo a fórmula de Bachelard. A pesquisa aparece, assim, como um modo particular de construir nossa própria convicção e de apresentá-la em circunstancias definidas. E tenhamos em mente a experiência: "eu acreditava que o sabia"” (p. 195)
} 
entrevistados ao tratar dos principais temas do estudo de caso, de modo a conferir maior objetividade à transmissão de informações.

As entrevistas foram realizadas com oito atores envolvidos nos procedimentos e contratos das linhas 4 e 6 . Foram feitas sete entrevistas, sendo a penúltima em conjunto com os entrevistados 6 e 7. Os entrevistados, como pode se depreender do Anexo 2, foram selecionados de forma a abranger todos as possíveis visões dos atores envolvidos, isto é: atores da administração direta do Estado de São Paulo, atores das empresas estatais, representantes dos interesses das concessionárias e consultores independentes das estatais e das concessionárias.

A partir das primeiras entrevistas, os demais entrevistados foram determinados pontualmente mediante indicação daqueles previamente entrevistados e da necessidade de coleta de dados. O número de entrevistas era inicialmente aberto e foi limitado por meio de saturação empírica. ${ }^{33}$

Todas as entrevistas foram concedidas mediante termo de consentimento e autorização para utilização dos dados em textos acadêmicos (Anexo 3). Como parte dos entrevistados preferiu não se identificar, de forma a dar unidade ao tratamento deles, optou-se pela desidentificação de todos. Os entrevistados foram numerados na ordem de realização das entrevistas e seus respectivos vínculos institucionais estão expostos no Anexo 2.

A utilização dos dados das entrevistas é um tema de controvérsia nas ciências sociais. Como conferir legitimidade às afirmações do pesquisador sem quebrar os eventuais compromissos de não identificação com os entrevistados? Na medida em que a disponibilização, em anexo, das transcrições integrais feitas pelo pesquisador poderia identificar os entrevistados, utilizou-se da seguinte alternativa para dar validade aos dados.

Vale-se apenas de trechos essenciais das entrevistas ao longo do trabalho, mas a íntegra dos áudios e das transcrições será enviada previamente aos membros da banca avaliadora de mestrado, de forma a conferir a certificação da veracidade das informações por meio de verificação de pessoas abalizadas e oficialmente designadas para tanto ${ }^{34}$.

\footnotetext{
33 “A saturação empírica designa, assim, o fenômeno pelo qual o pesquisador julga que os últimos documentos, entrevistas ou observações não trazem mais informações suficientemente novas, ou diferentes, para justificar uma ampliação do material empírico.” (PIRES, 2010b, p. 197)

${ }^{34}$ Lógica similar ao peer-review adotado pela grande maioria de revistas científicas.
} 


\section{CAPÍTULO 2 - PPPS: O APROFUNDAMENTO E A COMPLEXIFICAÇÃO DE UM MODELO}

Embora não seja o objetivo dessa dissertação compreender as razões da adoção do modelo de $\operatorname{PPPs}^{35}$, mas sim seu funcionamento e as razões das escolhas de instrumentos específicos para viabilizar as PPPs, a questão relativa às justificativas da adoção de um novo modelo dá ensejo à contextualização histórica que se pretende realizar nesse capítulo e auxiliam a compreensão da análise de evolução e aprendizado institucional que se almeja construir.

As respostas dos entrevistados ao questionamento acerca das razões da adoção do modelo são ilustrativas da visão dos atores a respeito dos pontos críticos que levaram a tais mudanças e de como o modelo de PPPs se diferencia das concessões comuns.

"Eu queria entender, na sua visão, quais motivos foram os principais para se adotar o modelo de PPP na linha 4?" (pergunta realizada ao entrevistado 3)

Entrevistado 3: Tem uma série de determinantes. Alguns inclusive macroeconômicos. Antes ainda das concessões comuns se transita de um modelo estatal para uma privatização de algumas empresas que eram industriais. O processo, no início, foi quase de devolver à operação privada empresas que haviam sido 'hospitalizadas' no BNDES. Depois passa-se a uma fase das privatizações de empresas industriais mas originalmente estatais (siderurgia, petroquímica, Vale) e às privatizações já com uma lei de concessões nova.

E, aí, você vai perceber que as PPPs vêm, no Brasil, se você pegar um trabalho inicial sobre PPPs de 2001 do Ministério do Planejamento, há a percepção de que várias infraestruturas não serão remuneradas por tarifas.

Então, a motivação inicial é uma questão de financiamento. É uma percepção clara de que, em várias áreas, principalmente nas infraestruturas que são mais capital intensivas - não estou falando de energia elétrica, que é capital intensiva mas que se remunera por tarifa, mas estradas, tipicamente, ferrovias, rodovias - e infraestruturas sociais que, ao redor do mundo, são modelos que

\footnotetext{
${ }^{35}$ Sabe-se que não foi desenhado um instrumental metodológico suficiente para alcançar a "real" resposta das razões para a promulgação de uma lei de PPPs e da sua adoção pelos entes federados. Entretanto, este não é objetivo dessa breve digressão. Pretende-se situar o leitor no contexto histórico das justificativas oficiais e das percepções acadêmicas sobre o processo de desestatização iniciado no Brasil nos anos 90 para, assim, poder compreender como o que foi implementado reflete (ou não) o que foi planejado e quais os possíveis rumos da oferta de serviços públicos no país.
} 
têm capital público, recursos orçamentários, do tesouro. Não tinha um modelo, apesar de existir teoricamente a ideia de que seria possível uma concessão subsidiada - o próprio $\mathrm{Mario}^{36}$ fala que isso poderia acontecer -, mas acho que a lei das PPPs deu um formato jurídico para esse tipo de concessão e, aí, introduziu a concessão administrativa, que é um modelo de compra diferente.

Há uma razão inicial, da transição do modelo, que é macroeconômica, financeira. Quem olhou a história das estatais brasileiras notou que algumas empresas tinham uma cara muito mais empresarial, de fato, Vale e Petrobras, duas empresas que funcionavam em regime de mercado, ambas internacionais; e você tinha uma série de outras empresas, Portobrás e Rede Ferroviária, que eram empresas que dependiam de recursos públicos para sua vida cotidiana.

Houve várias transições distintas das privatizações, algumas mais acertadas, outras menos, mas acho que a gênese da passagem é financeira e o esgotamento do modelo anterior.

Então, as PPPs, no fundo, a partir da lei, elas são uma parte financeira, tem uma questão de financiamento, você poder contar com o setor privado em áreas onde, de fato, você terá que participar seja direta ou indiretamente. Por outro lado, tem um modelo novo, que é o modelo mais próximo da experiência internacional, que é a compra de um serviço, nossa concessão administrativa é mais tipicamente o modelo inglês.

“Em especial, então, a linha 4 está nesse contexto?"

A linha 4, você tem que imaginar que ela começou a ser desenhada - nenhuma linha de metrô é implantada com menos de 5 a 10 anos de gente trabalhando, desenhando, colocando no mapa e olhando custos e etc-, então, quando ela começou a ser implantada, tinha um financiamento do Banco Mundial junto com o MetroSP. E para você avançar na implantação, se você pudesse contar com a participação privada, alavancar parte do financiamento via PPP, fazia sentido.

Estamos falando de 2004 e 2005, é em seguida à crise de 20022003, qualquer trajetória de "dívida x receita" do estado de São Paulo [mostra que] os anos posteriores são muito melhores que esse período. Então não se tinha espaço, limite de endividamento, para tomar financiamento diretamente pelo estado, tinha algumas coisas em curso já. Pareceu uma possibilidade razoável de se antecipar a linha fazendo uma PPP, de forma que o setor privado ficasse responsável por uma parcela do investimento. Era a ideia também de testar o modelo novo, estava dentro do contrato com o Banco Mundial, o IFC [International Finance Corporation, braço consultivo financeiro do Banco Mundial] já tinha feitos estudos

\footnotetext{
${ }^{36}$ Referência a Mario Engler Pinto Júnior, procurador do estado de São Paulo, à época, membro do Conselho Gestor do Programa de Parcerias Público-Privadas.
} 
extensamente antes sobre o setor privado no transporte ferroviário brasileiro.

A decisão final foi essa, na verdade, tentar trazer por meio da PPP um parceiro responsável por parte do investimento e pela operação da linha. Mas na linha 4 o projeto já estava em execução pelo MetroSP, era um modelo que já estava andando. Então, a escolha foi de trazer a operação, mas a implantação continuou inteiramente à cargo do MetroSP. Foi o MetroSP que continuou fazendo a obra, etc. Então, o que ficou de espaço para PPP foi investimento nos trens, sistemas e a operação. Havia um financiamento internacional, uma - digamos - sugestão de se tentar um modelo privado, que vinha do contrato com o Banco Mundial, que já tinha sido ensaiada e não tinha avançado e tinha a avaliação de que o modelo fazia sentido. Ou seja, a operação privada daquilo era algo desejável.

(...)Acho que os determinantes principais são esses: teve uma racionalidade financeira, em última instancia; e de modelo, de tentar um modelo novo naquele momento." (destaques feitos pelo autor)

Portanto, a seguir serão abordados os tópicos referentes à relação entre transporte público urbano e PPPs e às justificativas de adoção desse modelo dentro do contexto da Reforma do Estado.

Antes de avançar, porém, deve-se destacar que o termo "parceria públicoprivada" ou "PPP" será utilizado ao longo desta dissertação de duas maneiras distintas ${ }^{37}$. Quando se fizer menção a textos legais, contratuais e acadêmicos nacionais a referência será ao conceito de parceria público-privada em sentido estrito (ou seja, às duas formas de concessão instituídas pela lei 11.079/2004), quando a

\footnotetext{
${ }^{37}$ Essa ressalva é necessária para manter o rigor terminológico, no entanto, é também digno de nota que - normalmente - as parcerias público-privadas (em sentido amplo) que são celebradas fora do Brasil já têm, em seus respectivos regramentos jurídicos, permissões que foram trazidas no ordenamento brasileiro somente com a lei 11.079/2004, como a possibilidade de contraprestação pública de forma complementar à cobrança de tarifas e receitas alternativas, mecanismos de garantia fornecidos por ambas as partes, entre outros. Esses regramentos em outros países podem ter sido criados de forma estruturada e sistemática - como na Espanha, Itália, Chile e no próprio Brasil - ou podem ter sido adotados por meio de eliminação de restrições legais esparsas e, com isso, ter sido construído de forma mais pragmática e menos generalista - como no Reino Unido, Irlanda, Noruega e Finlândia (BRUZELIUS, 2005 apud DE JONG, 2010). Em sentido semelhante, após rigorosa análise conceitual sobre o fetichismo da doutrina em diferenciar as concessões comuns (lei 8.987/1995) e as novas modalidades da lei 11.079/2004, Vera Monteiro (2009) afirma que: “(...) Caberá ao contrato fazer as definições do modelo concreto, prescindindo, muitas vezes, de lei específica, pois bastará as que já existem. Aplicando-se o raciocínio, não há porque não aceitar que um contrato de concessão, confeccionado a partir de certa estrutura negocial, ultrapasse a barreira da lei que trata do modelo abstrato de concessão a ele subjacente e traga mecanismos de outra espécie de concessão. Trata-se do reconhecimento de verdadeira permeabilidade entre as espécies de concessão a partir do pressuposto de que são instrumentos que desempenham a mesma função. Isso só é possível com a caracterização do gênero 'concessão' pela sua função principal (viabilizar a realização de investimentos significativos para a disponibilização de bens e serviços à sociedade), e não como forma de delegação de atividade pública ao privado. (...)" (p. 187-188)
} 
referência for a textos estrangeiros far-se-á menção à ideia de parceria públicoprivada em sentido amplo, que define-se sucintamente como: forma de contratação de um empreendimento ou serviço de interesse público, com aporte de recursos financeiros ou não - de entes públicos e de entes privados, com repartição objetiva de riscos e de responsabilidades.

\section{1 - Transporte Público Urbano e PPPs}

\subsection{1 -Transporte Público Urbano - histórico e desafios}

O problema que deu origem a essa dissertação estava ligado à regulação do transporte público urbano e os instrumentos jurídicos capazes de promover seu melhor provimento.

A inquietação que levou a pesquisa a buscar o setor de transportes públicos adveio de uma combinação de dois fatores: inadequação da oferta de transporte público urbano na maior parte das cidades brasileiras e as implicações dessas questões de mobilidade com o desenvolvimento econômico e social, bem como com a desigualdade social ${ }^{38}$.

As deficiências do serviço de transporte público urbano no Brasil refletem, em grande medida, a falta de investimentos no setor a partir da segunda metade da década de $1980^{39}$ até o final dos anos $1990^{40}$, assim como o crescimento da opção

\footnotetext{
${ }^{38}$ Há uma forte iniquidade na forma como as políticas de mobilidade urbana são planejadas. Enquanto aproximadamente $60 \%$ da população dos grandes centros urbanos se vê dependente do transporte público urbano para se locomover (IPEA, 2011b), o espaço utilizado por modais de transporte particulares é de mais de $70 \%$ das vias públicas $(C N T, 2011)$ e os gastos com modais privados são quatro vezes maiores do que com transporte coletivo (ANTP, 2014). A disparidade de investimentos aliada ao fato de que o usuário de transportes privados é detentor de maior renda média do que o usuário dos demais modais (ANTP, 2014) reforça as desigualdades sociais no ambiente urbano.

39 "Se entre meados da década de 1970 e 1980 parecia haver considerável oferta de recursos federais para o financiamento de planos, infraestrutura e sistemas de transportes urbanos, na segunda metade dos anos 1980 e início dos anos 1990 houve uma estiagem nas fontes de recursos. Segundo Lima (1992), a receita tarifária e os recursos orçamentários (formado por arrecadação de tributos não vinculados) teriam constituído as principais fontes de financiamento do transporte público urbano até início dos anos 1980.

Com a crise fiscal do estado, a partir de 1982, a estiagem de fundos setoriais de financiamento suscitou a discussão em torno de fontes alternativas de financiamento (como taxas de transporte, contribuições de melhoria, selo pedágio, taxas de acessibilidade, títulos de privatização etc.) e a rediscussão do próprio conceito de tarifa e sua relação com teoria da produção no setor de transporte urbano (LIMA, 1992).

Embora a tarifa assumisse, cada vez mais, o papel da principal e mais permanente fonte de recursos, a fim de cobrir despesas de operação e custeio do transporte urbano, a falta de fontes extras de financiamento estáveis para provisão de infraestrutura adequada e a ausência de uma política de
} 
pelo transporte individual ${ }^{41}$ (BNDES, 1997; IPEA, 2011a ${ }^{42}$; NOBRE, 2004; VASCONCELLOS et al., 2011).

De acordo com a literatura (VASCONCELLOS et al, 2011; GOMIDE, 2008), para além da falta de "vontade política", a redução nos investimentos se deveu, principalmente, a dois fatores: a crise fiscal dos anos 80, e a municipalização e consequente desvinculação de recursos federais ao financiamento de transportes públicos operada pela Constituição Federal de $1988^{43}$.

Como resultado das décadas de ausência de investimento, gerou-se um significativo déficit de infraestrutura de transportes no Brasil e em São Paulo, que foi assim sintetizado em relatório elaborado pela revista The Economist (ECONOMIST INTELLIGENCE UNIT, 2011):

Em 2010, o produto interno bruto do Brasil (PIB) cresceu 7,5\% em termos reais (a taxa mais elevada em 25 anos). Depois de desacelerar para cerca de 3,6\% em 2011, o Economist Intelligence

financiamento para o setor conduziram à estagnação quase total dos investimentos ao longo da década de 1990." (VASCONCELLOS et al., 2011, p. 40)

40 "Embora as recomendações da política de transportes, desde pelo menos a década de 70 apregoem a prioridade ao transporte coletivo, o que se constata, de um modo geral, é justamente um aumento do transporte individual e uma queda do transporte realizado tanto por ônibus como sobre trilhos, notadamente quando comparados à evolução da população. (...) A política de financiamento sofreu, no entanto descontinuidades, a partir da década de 80, quando as dificuldades apresentadas ao financiamento do setor público impediram de se atingir as metas previstas de investimento no setor ferroviário, além de restringir também o financiamento aos Estados e Municípios, responsáveis, basicamente, pelo sistema rodoviário de passageiros." (BNDES, 1997, p. 6-7)

41 "Ao contrário dos outros serviços públicos (por exemplo, energia elétrica ou telefonia), que requerem que seus usuários estejam necessariamente conectados à rede, e para os quais não existem substitutos economicamente viáveis, o transporte coletivo tem, cada vez mais, nos veículos particulares (motocicletas e automóveis) um substituto. Ou seja, é possível a realização de viagens sem a utilização da rede de serviços. Isso mostra que a competição relevante no mercado de transporte urbano não se dá entre os modos de transporte público, mas, sobretudo, entre estes e o transporte individual motorizado. Tal fato não teria problemas, se não trouxesse consigo custos sociais, econômicos e ambientais para as cidades e seus habitantes. A necessidade de uma regulação do transporte urbano de maneira mais ampla, por- tanto, se justifica no crescimento dos congestionamentos de trânsito, da poluição do ar e da privação do acesso pelos mais pobres aos serviços nas grandes cidades, ou seja: nas perdas de bem-estar para toda a sociedade. Nesse sentido, a experiência internacional ensina que a sustentabilidade e o equilíbrio dos sistemas de mobilidade urbana só serão encontrados com a adoção simultânea e coordenada de políticas de melhoria sensível da qualidade do transporte coletivo; de integração das políticas urbanas, especialmente de transporte e uso do solo; e de racionalização ao uso de veículos particulares em certas áreas e períodos nas grandes cidades (a exemplo de Londres, Paris e Bogotá). Esse é o desafio.” (GOMIDE, 2005, p. 381)

42 De acordo com esta pesquisa, em 1977 os meios de transporte particulares (automóveis, taxis e "outros") representavam 34\% dos modais utilizados nos centros metropolitanos do Brasil, ao passo que esse número cresceu para $49 \%$ em 2005.

${ }^{43}$ Exceção feita à CIDE-Combustíveis, que tem a infraestrutura de transporte público como uma das três possíveis destinações de parte de sua arrecadação, sendo esta destinação obrigatória no tocante aos repasses aos Estados, Distrito Federal e Municípios, conforme se vê nos artigos 177, $\S 4^{\circ}$ e 159 , III da Constituição Federal de 1988. 
Unit prevê um crescimento médio anual de 4,5\% no médio prazo.

O desenvolvimento da infraestrutura de transporte público urbano está aquém ao crescimento econômico há décadas. As redes de metrô servem, relativamente, a poucos; os ônibus são quase sempre de baixa qualidade e lotados, além de competir por espaço com os carros particulares. Dadas essas condições, a classe média, em rápida expansão, escolheu carros e motocicletas como principal meio de transporte.

A infraestrutura de transportes é inadequada neste país de dimensões continentais. (...)

O metrô de São Paulo, o único sistema no Brasil que atinge altos padrões de qualidade, possui somente $74 \mathrm{~km}$ de extensão, para servir uma região metropolitana de 20 milhões de habitantes espalhada por uma área de 8 mil $\mathrm{km} 2$. O Rio (população: 11,5 milhões) possui menos de $50 \mathrm{~km}$. Por comparação, Madri oferece $300 \mathrm{~km}$ de trilhos para servir a uma população de 5 milhões de habitantes, enquanto a área metropolitana de Nova York (população: cerca de 19 milhões) possui mais de $400 \mathrm{~km}$ de trilhos subterrâneos.

A discrepância é parcialmente o resultado de um início tardio na construção de sistemas subterrâneos. O sistema de metrô de Londres funciona desde 1863, enquanto a primeira linha de São Paulo foi inaugurada em 1974. Mas a Cidade do México começou a construir seu sistema de metrô à mesma época que São Paulo e, agora, possui três vezes mais trilhos. (p. 3-5)

Desse modo, a justificativa de se socorrer às parcerias com o setor privado para fins de obter maior eficiência operacional e viabilizar a expansão da oferta desses serviços passou a estar presente no discurso político, ao longo da última década, como forma de solucionar o problema.

Conforme pode-se extrair do Caderno de Mobilidade Urbana do Ministério das Cidades, já em 2004 se afirmava que, em âmbito federal, "as parcerias públicoprivadas e os instrumentos do estatuto da cidade vêm sendo estudados como oportunidades para atração de investimentos em infraestrutura de transporte público." (BRASIL, 2004, p. 35)

No entanto, via de regra, os modais de transporte público em massa ${ }^{44}$ são financeiramente deficitários ${ }^{45}$. Isso dificultaria a utilização dos instrumentos da lei

\footnotetext{
${ }^{44}$ Ao se falar de transporte público de massa, está se falando de modais dependentes de infraestrutura autônoma e custosa (mass rapid transit). Maiores detalhes em Lender e Mandri-Perrot, 2012.

${ }^{45} \mathrm{O}$ percentual de subsídio público aos sistemas de transporte das principais capitais europeias varia de 20 a 75\%: Paris 20\%; Londres 25\%; Estocolmo 42\%; Bruxelas 44\%; Amsterdã 46\%; Berlin 54\%; Madrid 56\%; Praga 75\%. Conforme relatório da EMTA (2011).
} 
8.987/1995 nesses casos, inviabilizando a transição de um modelo de prestação do serviço pelo Estado (por meio de empresas estatais) para a iniciativa privada.

É justamente com o intuito de superar as limitações impostas pelo direito administrativo vigente que é publicada a lei federal 11.079 de 2004, que dispõe sobre normas gerais de licitação e contratação de parcerias público-privadas no âmbito da administração pública.

\subsection{2 - Antecedentes: Plano Nacional de Desestatizações, Reforma do Estado e Lei de Concessões}

A mencionada crise fiscal dos anos 1980 não afetou somente o setor de transportes públicos, suas repercussões nas economias mundial e, especialmente, latino-americana e brasileira foram consideráveis.

Como narram Arbix e Martin (2010), foi por conta da crise fiscal, que atingiu seu pico nos anos 1980, que se deu a erosão do modelo desenvolvimentista ${ }^{46}$ construído nas cinco décadas anteriores ${ }^{47}$. A partir dessa década, começa a prevalecer no discurso acadêmico e nas indicações de política econômica internacionais uma visão neoliberal do Estado ${ }^{48}$, que passa a surtir efeitos na política brasileira a partir de 1988 e perdura até 2004. (TRUBEK, COUTINHO e SCHAPIRO, 2012)

$\mathrm{Na}$ análise realizada por Trubek, Coutinho e Schapiro (2012), durante os "longos anos 90", a tônica das políticas e das reformas econômicas foi de adoção das prescrições do "Consenso de Washington". Isso, de acordo com os autores, estaria representado pela redução da carga tributária, privatização de empresas e serviços anteriormente de titularidade estatal, estabilização macroeconômica (com foco no controle inflacionário), redução de subsídios estatais a setores específicos da

\footnotetext{
46 "The debt and oil crises, which contributed to the erosion and collapse of the economy of Latin American and general and Brazil in particular, were the first great blow to the developmentalist edifice constructed over the 1940s, 1950s and 1960s and still operating albeit with greater difficulties in the 1970s."

${ }^{47}$ Como apontam Trubek, Coutinho e Schapiro (2012): "Like several other Latin American developing countries, Brazil had its classic developmentalist moment. From 1930 until the end of the 1980s, economic policies basically consisted of state-led initiatives to promote import substitution, industrialization and growth through state-owned enterprises, economic planning, price control, sectorial regulatory and administrative authorities and the use of tax and financial incentives."

${ }^{48}$ Os autores, entretanto, alertam que a adoção de políticas neoliberais no Brasil foi moderada e não tão forte como no Chile ou no México.
} 
economia, estímulo à competição no mercado, assinatura de tratados internacionais em propriedade intelectual e comércio internacional, entre outros aspectos.

Embora a construção desse histórico seja muito mais complexa do que a simples adoção de políticas e reformas neoliberais, haja visto que a Constituição Federal de 1988 é marcada por premissas sociais-democratas, importa destacar a emergência de um novo papel do Estado na economia que surge no Brasil nos anos 1990. (cf. TRUBEK, COUTINHO e SCHAPIRO, 2012)

Mattos (2002) esclarece esse ponto da seguinte forma:

A partir de 1990, com o Programa Nacional de Desestatização (PND), criado pela lei 8.031/90, o Estado brasileiro passa a mudar sua forma de atuação como agente produtor de bens e serviços em determinados setores da economia, iniciando um longo processo de privatização das empresas estatais e intensificando a concessão de serviços públicos à iniciativa privada. Nesse contexto, passa também a redimensionar sua atuação como agente normativo e regulador da atividade econômica, voltando-se para a criação de agências de regulação e intensificação da defesa da livre concorrência e da defesa do consumidor. (p. 55)

É nesse contexto e como decorrência dessas escolhas políticas (e daquelas contidas no "Plano Diretor da Reforma do Aparelho do Estado"49) que surge a lei 8.987 de 1995 ("lei de concessões”).

Ao narrar o histórico dos contratos de concessão no Brasil, dividindo essa evolução institucional em três fases que vão de meados do século XIX até a Lei de Concessões ${ }^{50}$, Ribeiro e Prado (2010) trazem considerações justamente a respeito da visão sobre o papel do Estado na economia que perpassa as leis 8.987 e 9.074, ambas de 1995:

(...) Do ponto de vista histórico, essas leis são produtos de uma inversão da tendência desenvolvimentista a partir da década de 1930, de intervenção direta do Estado no domínio econômico.

Nesse sentido, refletem a intenção de transferir para a iniciativa privada o investimento e a operação dos serviços públicos, com objetivos, entre outros, de (a) reduzir os compromissos de

\footnotetext{
${ }^{49}$ Sobre este documento e a respeito da reforma do "Estado patrimonial ao gerencial" ver BresserPereira (2001).

${ }^{50}$ Tipologia proposta por Carlos Ari Sundfeld em um seminário sobre PPPs em 2005. Ver nota de rodapé n. 35 em Ribeiro e Prado (2010, p. 37).
} 
investimento direto do Estado em setores nos quais é viável a exploração pela iniciativa privada, (b) permitir a concentração do Estado no provimento de serviços que não geram retornos suficientes para interessar a iniciativa privada e na regulação e fiscalização dos serviços públicos cuja exploração se tenha transferido para a iniciativa privada. Além disso, (c) buscou-se utilizar os recursos obtidos com a alienação das estatais e outros bens públicos para abatimento da divida pública. E, por fim, (d) pretendeu-se beneficiar a sociedade e o Estado com o aumento de eficiência trazida pela gestão privada dos serviços. (RIBEIRO e PRADO, 2010, p. 38-39)

Portanto, foi com o intuito de aprofundar (alcançar serviços públicos ainda não operados pela iniciativa privada por razões financeiras) e de complexificar (possibilitar a conjugação de objetos anteriormente submetidos aos casos da lei 8.987/1995 e da lei 8.666/1993, isto é, concessão de serviços públicos com realização de obras e serviços, no mesmo instrumento contratual; além de envolver efetiva repartição de riscos e atribuições entre agentes públicos e privados e não mais a simples delegação à iniciativa privada) as possibilidades de escolhas públicas e o modelo de concessões em vigor que surge a necessidade de se elaborar a lei de PPPs.

\subsection{3 - As Parcerias Público-Privadas - fundamentos e escolhas políticas}

A exposição de motivos do projeto de lei número $2.546 / 2003^{51}$, que deu origem à lei $11.079 / 2004^{52}$, esclareceu os objetivos políticos da edição da lei de PPPs nos seguintes termos:

A proposta de Projeto de Lei foi elaborada com o objetivo de adaptar o atual marco legal de contratação (Lei no 8.666, de 1993) e de concessão de serviços (Leis no 8.987 e 9.074, ambas de 1995), permitindo algumas alterações que potencializem o sistema de

\footnotetext{
${ }^{51}$ Importante destacar que o histórico da lei de PPPs brasileira exposto por Ribeiro e Prado (2010) deixa claro o envolvimento de instituições internacionais na formulação do projeto de lei que deu origem à lei 11.079 de 2004. Entre os quais, há expressa menção ao PNUD (Programa das Nações Unidas para o Desenvolvimento) e ao BID (Banco Interamericano de Desenvolvimento). Isso, em alguma medida, corrobora a posição dos entrevistados citados no início do capítulo a respeito da influência de organismos internacionais na criação desse arcabouço institucional favorável à operação privada de serviços públicos no Brasil.

52 Em 2004, igualmente, o Estado de São Paulo promulgou sua lei estadual de parcerias públicoprivadas, lei número 11.688 de 2004, bem como o decreto estadual n. 48.867 de 2004. Ambos instituíram o programa de parcerias público-privadas do estado e a companhia paulista de parcerias (braço operacional do programa).Essas leis foram essenciais para a celebração da primeiro contrato de parceria público-privada do país, o da linha 4 do metrô de São Paulo.
} 
parceria e o seu elemento de distinção: compartilhamento dos riscos e financiamento privado. (BRASIL, 2003, p. 7)

Os objetivos oficialmente divulgados, em grande medida (ainda que sinteticamente), resumem as justificativas político-econômicas e jurídicas para a implantação das PPPs que são expostas a seguir.

No plano político-econômico, busca-se justificar a adoção das PPPs, via de regra, por questões de eficiência e de inovação. Alega-se que as PPPs promovem acesso a novas formas e fontes de financiamento e a novas tecnologias, viabilizando inovações técnicas e melhorando a prestação e a manutenção dos serviços. (BANCO MUNDIAL, 2012b)

De acordo com Trebilcock e Daniels (1996), um dos principais fatores de eficiência de prestação de serviços públicos por meio de parcerias com o setor privado encontra-se, paradoxalmente, na maior dificuldade de acesso a crédito que os parceiros privados enfrentam. Essa dificuldade de acesso a crédito faz com que o financiamento de projeto proposto pelo parceiro privado seja submetido a análises criteriosas pelos financiadores quanto a sua qualidade, rentabilidade e performance, $o$ que culmina por incrementar a performance do serviço. ${ }^{53}$ Dessa forma, a

\footnotetext{
${ }^{53}$ Esse aparente paradoxo é esclarecido da seguinte forma: “(...) both the design and construction functions are highly sensitive to incentives created by the nature of the financing function. The nature of these cross-function incentives effects (interdependencies) are key to understanding what superficially may appear to be one of the major mysteries of private sector financing of infrastructure projects. In most cases, private sector financing will carry a higher cost of capital than government financing, simply because the default risk on sovereign debt (given that governments have access to the entire taxpayer base) is obviously lower than for a private sector infrastructure provider, where the cost of capital will reflect both project-specific risks and its de jure or de facto limited liability. Thus, if the financing function were viewed in isolation from the other functions, given the lower cost of sovereign debt relate to private sector debt, we should see governments financing all activities in the economy. The fact that they finance vey few of these activities, at least in a market economy, requires an explanation. In the present context, the explanation appears to lie in the fact that while the cost of capital to the private sector infrastructure provider will be higher than the cost of an equivalent amount of capital to the government (which has the same access to private capital markets), offsetting efficiency gains from the other functions performed by the private sector provider are influenced positively by virtue of the fact that it is bearing the financial risk on the project. However, this tradeoff in turn depends upon how the capital investment is to be recouped. If the investment must be recouped from competitively determined revenues from the project, then this will create socially appropriate incentives with respect to the design, construction, operation, and maintenance of projects. While it may be true that governments and private sector infrastructure developers borrow capital from the same sources, lenders' incentives with respect to the private sector project financing are sharply different. With the government as borrower, lenders can ignore project-specific returns, given that lenders ultimately have access to the governments' entire tax and asset base. With project financing, project returns become central; lenders are likely to screen development consortia more carefully before lending, to insist on adequate security and financial penalties against non-completion or default, and to monitor performance more closely through the inclusion of numerous, tailored covenants than they would if they were lending to government which in turn then financed the project, thus
} 
credibilidade de estar associado ao parceiro público permite que o prestador privado tenha acesso a financiamentos que de outro modo não teria e, assim, possa desempenhar projetos de forma mais eficiente e de maior escala. O que, em tese, aliado aos fatores de eficiência e de inovação, possibilitaria uma relação de "ganhaganha" entre os agentes.

Do ponto de vista jurídico-financeiro, diz-se que as razões para adoção do modelo de PPPs no Brasil se ligam à necessidade de promover investimentos em infraestrutura sem impactar o nível de endividamento estatal e viabilizar acesso de investimentos privados aos serviços deficitários, cujas receitas tarifárias possam ser complementadas por contraprestações e aportes financeiros públicos. (RIBEIRO e PRADO, 2010; MARQUES NETO, 2011)

Para além de justificativas para a adoção deste modelo de contratação, entidades internacionais (BANCO MUNDIAL, 2012b; OCDE, 2008; IFC, 2012) bem como as literaturas econômica (DE JONG et al, 2010; DELMON, 2010) e jurídica (WILLOUGHBY, 2013; MEYER e ENEI, 2004; TREBILCOCK e ROSENSTOCK, 2013), estabelecem condições institucionais para a viabilidade da celebração de parcerias público-privadas. De maneira geral, essas condições institucionais podem ser resumidas nos seguintes requisitos ${ }^{54}$ :

- Possibilidade de criação de uma sociedade de propósito específico (SPE);

- Desimpedimento do funcionamento dessa SPE nas atividades relacionadas ao projeto;

- Possibilidade de fornecimento de subsídios do governo ao parceiro privado;

- Viabilidade de transferência de recursos, financeiros ou não, para o parceiro;

- Sistema judiciário imparcial e eficiente;

significantly improving the performance of the infrastructure provider." (TREBILCOCK e DANIELS, 1996, p. 401-402)

${ }^{54}$ As principais características dos modelos sugeridos por entidades internacionais e pela literatura jurídica e econômica foram mapeadas em revisão de literatura e são apresentadas de forma esquemática por razões de adequação ao propósito desse capítulo. Não se encontra entre os objetivos centrais da pesquisa uma discussão detalhada da literatura sobre as PPPs, mas sim sua efetiva aplicação pelo Estado de São Paulo. Dessa forma, para fins de apresentação conceitual, a organização esquemática pareceu ser a forma mais adequada de expor o conteúdo da revisão bibliográfica realizada. 
- Legislação que permita divisão objetiva de riscos;

- Asseguração legal do recebimento das tarifas;

- Previsão legal - transparente e imparcial - de procedimentos licitatórios e contratuais;

- Viabilidade de comprometimento do orçamento público por longos períodos;

- Experiência dos órgãos governamentais com contratações;

De acordo com a literatura jurídica brasileira (SUNDFELD, 2011; MARQUES NETO e SCHIRATO, 2011; RIBEIRO e PRADO, 2010; MONTEIRO, 2009; RIBEIRO, 2011), a lei 11.079 de 2004 trouxe diversos mecanismos para viabilizar o atendimento destes requisitos ${ }^{55}$, entre os quais pode-se mencionar as mais importantes inovações e aplicações:

- Possibilidade de contraprestação pecuniária pública ao concessionário privado (i.e. complementação de tarifa de serviços deficitários);

- Existência de mecanismos de garantia do parceiro público ao privado;

- Possibilidade de previsão de cláusula arbitral;

- Permissão de utilização do "procedimento de manifestação de interesse";

- Remuneração vinculada ao desempenho;

- Possibilidade de conjugação, em um mesmo contrato, de obra pública e concessão de serviço público, sem especificação de projeto básico, viabilizando ganhos de eficiência na forma de construir e de operar o serviço pelo parceiro privado.

No entanto, como visto no tópico anterior, a lei parece representar apenas a institucionalização de um projeto - já em curso desde o final dos anos 90 - de adoção de um modelo de parcerias entre setor público e entidades privadas. (SUNDFELD, 2011b; MONTEIRO, 2009; RIBEIRO e PRADO, 2010)

No mesmo sentido, Ribeiro e Prado (2010):

\footnotetext{
${ }^{55}$ Alguns já existiam no ordenamento jurídico brasileiro, mas foram também aplicados às concessões administrativas e patrocinadas, como as disposições da lei de concessões. Outros decorrem de amadurecimento institucional mais amplo que a simples positivação de uma lei, como a garantia de um sistema judiciário imparcial e eficiente.
} 
No cumprimento desses dois objetivos, a lei de PPP buscou, por um lado, tanto quanto possível, preservar e aproveitar o arcabouço legal e institucional montado ao longo dos anos 90 para a realização dos processos de desestatização. Doutro lado, tratou de incorporar a esse arcabouço inovações ou aperfeiçoamentos que provieram de duas origens: da experiência acumulada no âmbito das Agências Reguladoras na lida com contratos de concessão e do Direito Comparado (p. 47)

Esse processo de evolução jurídico-legislativa pode ser interpretado como reflexo de outro processo mais amplo, que foi identificado por - entre outros - Arbix e Martin (2010) como o Novo Ativismo Estatal (NAE). Para os autores, essa nova forma de atuação do Estado na economia seria caracterizada pelo "favorecimento a intervenções de mercado por meio de políticas de competitividade conjugadas com o fornecimento de serviços sociais". Esses fatores conjugariam "a inclusão nos mercados daqueles anteriormente excluídos socialmente e não somente a transferência de renda aos pobres." (ARBIX e MARTIN, 2010)

Para Coutinho e Schapiro (2013), no novo ativismo estatal, o direito (especialmente o econômico) está:

intensamente associado à função desafiadora de fomentar a funcionalidade das instituições em função de seus objetivos concretos. Esse papel tem se tornado central no contexto da ação seletiva do Estado, em que a governança e a efetividade das ações públicas se revelam chave. Esse papel resulta ainda do contexto democrático em que o ativismo do Estado se estabelece, isto é, desse contexto decorre o desafio de se governar reformas institucionais e a construção de arranjos que sejam economicamente efetivos e politicamente responsivos. A tarefa de governança, portanto, envolve imaginação institucional para mapear problemas e formular normativamente novas arquiteturas institucionais.

A narrativa conceitual e histórica elaborada até aqui indica haver algum tipo de relação entre a adoção de novos instrumentos jurídicos a partir da definição político-ideológica dos papéis do Estado na economia. Ela também é fundada na noção já sucintamente analisada no capítulo anterior do que são as "instituições" para as ciências sociais aplicadas e do seu papel no desenvolvimento.

Esclarecidas as bases conceituais e históricas sobre as quais se realizou a pesquisa, torna-se possível iniciar a análise do caso. 


\section{CAPÍTULO 3 - O ESTUdO DE CASO: ARRANJOS INSTITUCIONAIS E INSTRUMENTOS JURÍDICOS DAS LINHAS 4 E 6 DE METRÔ EM SÃO PAULO}

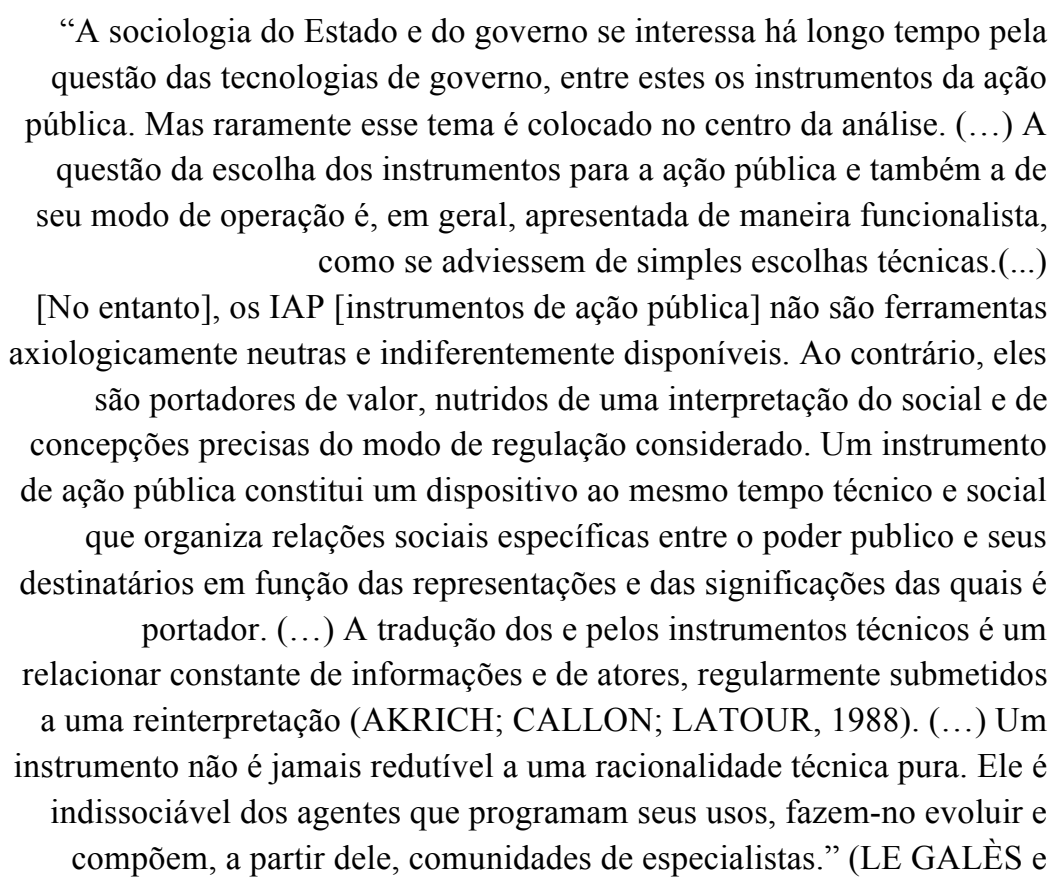

LASCOUMES, 2012, p. 20-22)

Ao longo desse capítulo serão analisados os procedimentos de contratação das linhas 4 e 6 de metrô em São Paulo e alguns aspectos da implementação do contrato da linha 4. Como a linha 6 teve seu contrato celebrado mais recentemente e ainda encontra-se em fase inicial de obras, a análise de sua implementação fica limitada.

Inicia-se pelo histórico da linha 4 e, posteriormente, narra-se a experiência da linha 6, comparando-a com aquela. Para facilitar o entendimento das características de cada projeto (linha 4 e linha 6) e dos documentos mencionados, foi criado um anexo específicos contendo os principais documentos dos casos online (Anexo 4).

Por fim, de forma a dar fluidez textual à análise do caso, ao se mencionar cláusulas contratuais das concessões patrocinadas das linhas 4 e 6 , elas não serão transcritas no corpo do texto. Mas, para fins de verificação e de melhor compreensão do conteúdo, todas as cláusulas expressamente mencionadas constam dos Anexos 6 e 7. 


\section{1 - Linha 4 do Metrô - O Modelo de Transição}

É evidente que as questões relatadas no capítulo anterior a respeito da ingerência do Banco Mundial na definição dos instrumentos jurídicos utilizados internamente nos países e na determinação, em abstrato, de instituições específicas que definem o desenvolvimento de um país perpassam a temática das PPPs e podem muito bem estar por trás de todo seu desenvolvimento no Brasil ${ }^{56}$. Contudo, ainda que necessária, a contextualização realizada não daria conta de responder, com rigor científico, uma pergunta que sequer foi feita ao se iniciar a pesquisa.

Muitos fatores podem ter levado o Brasil e o Estado de São Paulo a adotar as PPPs, como aspectos financeiros ou mesmo político-ideológicos. No entanto, o que há de concreto para ser analisado - nos termos e dentro das possibilidades dessa pesquisa - é que o Estado de São Paulo, em 2002 (após negociações iniciadas em 1998), contratou um financiamento com o Banco Interamericano para Reconstrução e Desenvolvimento (BIRD - integrante do grupo do Banco Mundial) para viabilizar a construção das obras da linha 4 e, com isso, ficou condicionado à utilização de instrumentos que permitissem à iniciativa privada a operação do serviço.

Sendo assim, a condição tinha que ser cumprida. Nesse ponto, as dúvidas jurídicas surgem e o escopo dessa pesquisa fica delineado nos termos colocados pelo entrevistado 2:

O negócio chamado metrô, enquanto negócio, é um mau negócio e é autofágico (...) Quando eu digo que ele é autodestrutivo do ponto de vista econômico é porque, na medida em que você cresce e oferece mais serviço, você não gera proporcionalmente novos passageiros para pagar o serviço. Na verdade você gera novos passageiros, mas você faz com que os passageiros atuais vão se realocando no sistema de maneira que a tarifa média vai diluindo, caindo.

\footnotetext{
${ }^{56}$ Vera Monteiro (2009) pontuou essa questão da seguinte maneira: “Ainda que o discurso político corrente no momento da edição da Lei n. 11.079/04 tenha vinculado a criação dessas duas novas espécies concessórias à crise fiscal e de capacidade de investimento do Estado brasileiro - ao menos aos olhos do profissional do mundo das leis -, a alteração legislativa surgiu muito mais como resultado de um movimento pautado pela incorporação (normativa) de novos mecanismos em matéria de contratos públicos (ver capítulo II a respeito), do que propriamente por conta da tão propalada incapacidade de investimento público. Noutras palavras, do ponto de vista jurídico, as razões políticas e econômicas que levaram o Governo federal a editar a Lei n. 11.079/04 serviram para concretizar um movimento (jurídico), que já existia, de revisão do modo de relacionamento entre o público e o privado nas relações contratuais.” (p. 141)
} 
Eu estou falando isso para voltar lá em 1998, porque quando o Banco Mundial diz "olha, você vai ter que fazer a concessão", o governo de SP pensa "como vou fazer a concessão? Eu não posso dar subsídios para a concessionária." Estamos sob o regime da lei $8987 / 1998$, em que o estado não pode subsidiar a tarifa. Portanto, os únicos serviços passíveis de concessão são aqueles em que as internalidades sustentam o negócio. Não é o caso do metrô. E aí o governo volta para o BM e diz "Nós podemos tentar, mas com o que tem de lei no Brasil hoje não vai dar." E aí fica uma cláusula no empréstimo dizendo que o BM poderá considerar cumprida a obrigação se o Governo de SP demonstrar através de estudos que é inviável fazer a concessão.

Bom, começa a licitação da obra estrutura da seguinte forma: túneis - obra civil -, sistema de energia, sistemas auxiliares e as estações, o Estado faz; trem e sistema de sinalização - resumindo -, é um problema para depois a gente ver quem vai fazer.

(...) E aí eu entro na Companhia do Metropolitano em 2002 com essa licitação da obra e sistema de energia em curso. E ainda sem ninguém saber como iria "botar o trem na linha". A gente até brincava que se não desse certo a compra dos trens, nós teríamos a maior ciclovia subterrânea do planeta.

Então, "como" o direito foi utilizado para "resolver o problema" é o que se buscará narrar a seguir.

\subsection{1 - Diálogo Público-Privado}

Como visto, o financiamento foi obtido em 2002 e também nesse ano a Companhia do Metropolitano de São Paulo, responsável pelas obras, iniciou as contratações dessas (nos termos da lei 8.666/1993). No entanto, ainda restava a dúvida do que se fazer após a conclusão das obras: como conceder a operação de um serviço deficitário à iniciativa privada em 2002 no Brasil? Como compreender o "apetite" do mercado por essa concessão?

Por essa razão, contratou-se ${ }^{57}$ um consultor com experiência em modelagem financeira de concessões para auxiliar na compreensão do apetite do mercado e nas possibilidades jurídicas existentes.

Dessa forma, ainda que o Estado de São Paulo já tivesse capacidade técnica e experiência acumulada na realização de obras de metrô (por meio do MetroSP ${ }^{58}$ ) e na

\footnotetext{
${ }^{57}$ Contrato n. 0035289401/2003 entre o Unibanco e o MetroSP.
} 
concessão de serviços públicos (rodovias), não o tinha para compreender o novo cenário e a intenção dos atores de entrar nesse mercado.

Como fazer isso sem ofender os princípios da administração pública do artigo 37 da Constituição Federal? Como dialogar com potenciais parceiros privados sem incorrer em suspeitas de corrupção? ${ }^{59}$

O desafio posto à administração pública, em um cenário de ativismo estatal, é de dupla ordem: ela deve apresentar resultados e atuar com eficiência (conforme proposto pela Emenda Constitucional 19/1998), no entanto, os órgãos de controle e o judiciário possuem grande ingerência na atuação administrativa ${ }^{60}$, buscando, inclusive, a responsabilização pessoal dos administradores nos casos de desvios de conduta. Portanto, deve-se buscar as melhores escolhas para o ente público, mas os fóruns de obtenção de informação a respeito do mercado são limitados àqueles de atuação formal.

A contratação do consultor (ou advisor, como foi chamado por diversos entrevistados), assim, surgiu como uma alternativa e ilustrou uma solução a dois problemas: falta de conhecimento de mercado (modelagem financeira de um mercado até então desconhecido e sem prévias experiências nacionais ${ }^{61}$ ) e ausência de canal formal de diálogo continuado entre os setores público e privado.

Essa perspectiva ficou evidente, novamente, nas falas dos entrevistados 1 e 2:

Entrevistado 1: Na linha 4 você tinha a figura de um advisor do poder público, que era o Unibanco. Não era o advisor dos sonhos,

\footnotetext{
${ }^{58}$ Essa capacidade técnica é mencionada como existente e indispensável em todas as entrevistas e perpassa diversas citações ao longo do trabalho.

${ }^{59}$ Essa preocupação é evidente no discurso dos entrevistados e o obstáculo jurídico-institucional sobressai no seguinte trecho da fala do entrevistado 4 sobre diálogo institucional, consultores e PMI: "Agora, órgãos de controle têm um pouco essa visão fantasiosa do mundo, que os órgãos públicos não podem conversar com o mercado, não podem receber papéis do mercado dizendo 'olha, isso aqui é uma boa ideia', 'isso aqui é um bom termo de referência'.

O mundo funciona assim. Por que a administração pública não pode? Então a administração pública ficou - em razão de processos em que há desvios de conduta - muito amarrada. E aí ela fica sem flexibilidade, ela não sabe como lidar com essa relação."

${ }^{60}$ A falta de clareza a respeito do que efetivamente é e do que deve ser objeto de controle foi relatada, no âmbito dos órgãos de controle da União, como um dos principais problemas na interação "controlador-controlado" no relatório " Coordenação do sistema de controle da administração pública federal" da série "Pensando o Direito" do Ministério da Justiça (2012). Embora o estudo tenha como objeto empírico a administração pública federal, os resultados refletem as mesmas preocupações dos entrevistados no caso do estado de São Paulo.

${ }^{61}$ A questão das capacidades institucionais já começa a ser apontada ao se esbarrar com esse problema, ela ficará mais clara ao longo do trabalho e seu conceito será trabalhado ainda nesse capítulo.
} 
tinha uma estrutura limitada pra mobilizar pra esse projeto, até porque foi um projeto que levou muito tempo para avança, mas ele cumpriu bem o papel de intermediário entre o setor público e o setor privado. Ele fazia isso de uma forma muito institucional, ele ouvia o setor privado, tinha reuniões com o governo para trazer as percepções, filtrar as percepções, opinar sobre elas e propor quais eram as realmente relevantes e quais não eram. Ele promoveu vários encontros entre as equipes técnicas do governo e esses players. Fazendo isso nas instalações do banco, noticiava que quem quisesse vir podia dialogar. Organizava as reuniões, porque, às vezes, se você bota dois competidores numa mesma sala nenhum vai abrir a boca. Então se fazia reuniões separadas com a mesma equipe, fazia-se atas dessas reuniões.

Entrevistado 2: Era o Unibanco que conversava com o setor privado. A gente não tinha contato com eles. Por isso que eu sempre fui, depois acabei derrotado nessas discussões dentro do governo do estado, favorável a contratar. (...) Porque quem decide se vai ou não vai haver financiamento, é um banco. Portanto, se você tem um banco do seu lado, você passa a ter um olhar do financiador, que é um olhar diferente do seu (público), que é diferente do investidor, que é diferente do operador. Você passa a ter contato direto com essa figura, que tem um olhar muito peculiar sobre um projeto desse e, portanto, ele faz com que você ganhe muito tempo dizendo "não adianta você colocar isso no edital, isso é legal pra você, mas não vai ter um licitante porque não tem banco que financie". Ele [também] faz uma ponte com o setor privado que você, e ainda mais agora depois dessa discussão de cartel - e, com todo respeito, com uma quantidade de ignorância que vem na esteira dessas discussões; as pessoas acham que o administrador público não pode conversar com o setor privado, então como você contrata, por exemplo, a fabricação de um trem? Você compra um trem e não pode conversar com a empresa? Enfim, o banco cumpre esse papel para a gente, ele dizia: "olha, eu conversei com o banco $\mathrm{X}$ e ele diz que se for assim ele não vem, mas isso é bobagem, ele vem sim; agora, essa outra questão ele não vem mesmo". E depois, por uma série de razões, o estado decidiu não mais fazer essas contratações, o que eu lamento muito. Acho que seria mais rápido e teríamos modelos melhores se o estado tivesse assessoria de bancos privados.

Embora a qualidade do Unibanco como consultor tenha sido questionada em diversos pontos das entrevistas ${ }^{62}$, a utilização - em teoria - dessa figura foi altamente

\footnotetext{
${ }^{62}$ Entrevistados 1, 2, 4 e 8 foram expressos ao relatar limitações e até mesmo frustrações com o trabalho realizado. Especialmente no tocante à modelagem jurídica, esperava-se que o consultor pudesse auxiliar mais do que efetivamente o fez. Na realidade, consultores jurídicos independentes
} 
recomendada por todos envolvidos no processo de elaboração do edital. As vantagens geradas por essa alternativa compreendem, como dito, a solução de dois entraves altamente interconectados: capacidade técnica (modelagem financeira) e diálogo com a iniciativa privada. ${ }^{63}$

Dessa forma, a contratação de consultoria, já prevista no artigo 21 da lei 8.987/1995 e aplicada à lei 11.079, foi utilizada, nesse caso, como uma alternativa institucional às limitações administrativas e jurídicas existentes.

A partir dos diálogos realizados, da experiência angariada ao longo das concessões que antecederam, das necessidades específicas do projeto e dos interesses dos atores relevantes (financiadores, Governo Estadual, MetroSP, população, potenciais parceiros, entre outros), chegou-se ${ }^{64}$ à conclusão de que os pontos críticos do projeto eram: contratação de garantias exequíveis (tópico 3.1.2.1), definição de um sistema tarifário financeiramente e politicamente viável (3.1.2.2), construção de um sistema de pagamentos confiável e líquido (3.1.2.3) e divisão adequada de riscos (3.1.2.4). A descrição desses pontos vai ao encontro da proposta de quatro variáveis de análise elaborada no capítulo metodológico, compreendendo, em grande medida, os temas centrais previamente estipulados para fins de análise de conteúdo.

tiveram que ser contratados pelo MetroSP para socorrer o projeto e, em parceria com a Procuradoria Geral do Estado e com o corpo jurídico do MetroSP, elaborar o edital da PPP.

${ }^{63} \mathrm{O}$ entrevistado 4 deixou clara sua posição quanto a essencialidade e a abrangência da atuação dos consultores nesses projetos, nos seguintes termos: "No começo da minha vida nesses projetos, eu tinha uma impressão de que esse papel era um pouco superficial. Hoje eu estou seguro de que é um papel importante. Porque é difícil você coordenar um grupo multidisciplinar; é difícil você transformar a informação; é difícil você fazer com que a informação de todos os grupos se conversem; é difícil você ter interlocução com os órgãos públicos. Então, a figura do advisor é muito importante. Porque mesmo que o órgão público queira fazer o projeto, alguém tem que ir lá buscar a informação dele, ou a informação não sai. (...)Ele tem primeiro esse papel de ajudar a sacar as informações e os dados dos órgãos públicos. Os órgãos públicos não têm as informações organizadas. Então, surgem as ideias, surgem as propostas e isso tudo precisa ser levado, precisa ser testado, articulado. E o advisor ajuda a fazer esse papel. O advisor ajuda a fazer esse papel de articulação interna, dentro do próprio governo, ligando as pessoas. Com a iniciativa privada, ele também tem um papel fundamental que é o de testar as propostas. Isso é relevantíssimo. Senão, o projeto some, vira um projeto natimorto. E testar não só quando o projeto está pronto. São vários aspectos do projeto que precisam ser testados. Testar não só a viabilidade de o mercado comprar o projeto, mas os aspectos ambientais, os aspectos técnicos, então ele vai testando a viabilidade intrínseca do próprio projeto."

${ }^{64}$ Esses pontos foram sistematicamente enumerados pelo entrevistado 2 e corroborados pelas demais entrevistas. Tais pontos são analisados isolada e detidamente ao longo do tópico 4.1.2. 


\subsection{2 - As soluções contratuais}

\subsubsection{1 - Os mecanismos de garantia}

Entrevistado 1: E o grande risco nessa linha, e a realidade ex post mostrou isso, era a interface entre a obra civil que era contratada [pelo Estado] e a operação [concessionário]. O grande risco que se corria era a obra não ficar pronta nas condições, tempo e modo devidos, e a operação não poder se iniciar, prejudicando o concessionário $^{65}$. Acho que o foco principal do contrato da linha 4 foi como motivar suficientemente o governo, no caso o MetroSP, a cumprir a obrigação de execução da obra no tempo e modo devidos e como dar conforto ao parceiro privado de que ele estava coberto contra eventuais prejuízos que esse atraso pudesse lhe causar.

A experiência nacional em contratações públicas compreende o recebimento de garantias por parte dos concessionários, mas, nesse ponto, a lei de PPPs inovou no ordenamento jurídico brasileiro ao permitir pagamentos de contraprestações ao parceiro privado e, consequentemente, a possibilidade de concessão de garantias do Poder Público ao parceiro privado.

Como não há meios efetivos de se executar valores devidos pela Fazenda Pública no Brasil sem incorrer na obrigação do precatório (artigo 100 da Constituição Federal), a lei de PPPs previu no artigo $8^{\circ}$ formas de destinação patrimonial específica e desimpedimento desse patrimônio para fins de garantias ${ }^{66}$.

Conforme descrito na cláusula décima primeira do contrato da linha 4 , as obrigações do poder público garantidas por instrumento formal foram: pagamento das contraprestações, multas por atraso na entrega das obras, multas por atraso na emissão da ordem de serviço e multa por rescisão injustificada.

Como havia um alto grau de incerteza a respeito da implantação do novo modelo de contratação e de remuneração e o risco de atraso nas obras pelo MetroSP era considerado alto, o sistema de garantias oferecido pelo poder concedente buscava dar a máxima confiabilidade possível ao concessionário. Conforme ressaltou o entrevistado 3:

\footnotetext{
${ }^{65}$ Como mencionado pelo entrevistado, esse risco se concretizou. Em parte, devido ao acidente na estação Pinheiros (ver Terra, 2007), as obras foram concluídas com considerável atraso, criando um alto custo de oportunidade para a concessionária, por ficar inviabilizada de operar e gerar receitas tarifárias.

${ }^{66}$ Uma detida análise do sistema de garantias na lei de PPP pode ser encontrada em Schirato (2011).
} 
A garantia foi para um risco relevante e teve um valor relevante, porque no fundo tinha um custo nessa garantia inicial: fazer o processo todo crível. Ou seja, eu tenho um custo de prime mover ${ }^{67}$, estou indo e dou uma garantia forte para ser algo crível do ponto de vista do privado. Então, acho que tem um custo; provavelmente não se daria uma garantia desse tamanho ${ }^{68}$ em projetos posteriores porque não precisa. Mas, naquele momento, eu estou falando de uma taxa da juros diferente, de um risco Brasil diferente, do primeiro contrato de PPP, [enfim] da mudança de modelo. (destaque do autor)

Logo, o instrumento de garantia escolhido para atender às necessidades do caso deveria passar segurança ao mercado de que o modelo de PPPs a ser implantado era "crível" e que ele (agente privado), enquanto entrante nesse mercado ainda não explorado, poderia confiar no cumprimento das obrigações do Estado.

A forma mais atraente para o concessionário, portanto, deveria envolver a impossibilidade de submissão ao regime de precatórios, o afastamento de discussões sobre existência de crédito e a liquidez dos ativos dados em garantia.

Por essas razões, optou-se pelo modelo de garantia descrito na cláusula décima-primeira (subitens 11.13 e 11.14, transcritos no Anexo 5). Nesse modelo, a Companhia Paulista de Parcerias (CPP) assumiu a condição de fiadora das obrigações acima mencionadas. Como forma de assegurar que a fiança prestada implicaria, efetivamente, no pagamento de valores eventualmente devidos à título de compensação ou multa, a CPP, no mesmo ato, comprometeu-se a dar em penhor quotas de fundo de investimento constituído para esse fim.

Dessa forma, o arranjo contratual orquestrado, ilustrado no Quadro 1, foi o que segue. A Companhia Paulista de Parcerias (CPP) ${ }^{69}$ aplicou recursos em um Fundo de Investimentos ${ }^{70}$ composto por títulos da dívida pública com projeção de rendimento superior à atualização monetária das contraprestações ${ }^{71}$. Após a alocação

\footnotetext{
${ }^{67}$ Expressão utilizada no sentido de pioneirismo na utilização de instrumentos ainda não conhecidos pelo Estado e pelo mercado.

${ }^{68}$ A avaliação do valor oferecido face ao efetivamente necessário foge ao escopo e às possibilidades dessa pesquisa. Entretanto, o estudo econômico-financeiro de Brandão et al (2012) corrobora o entendimento do entrevistado 3 de que os valores ofertados foram acima do necessário.

${ }^{69}$ Empresa estatal criada especificamente para colaborar, apoiar e viabilizar o programa de PPPs do Estado de São Paulo, vide Anexo 3.

${ }^{70}$ A criação desse Fundo de Investimentos se deu por registrado de atos constitutivos no 10 ofício de Títulos e Documentos de São Paulo, conforme descrição no anexo 4.

${ }^{71}$ As condições desse penhor estão disponíveis no Contrato de Penhor e outras avenças pactuado entre a CPP e a Concessionária da linha 4 , mencionado no anexo 4.
} 
de recursos nesse fundo de investimento, a CPP deu em penhor as quotas do fundo como garantia das obrigações que assumiu a título de fiadora no contrato.

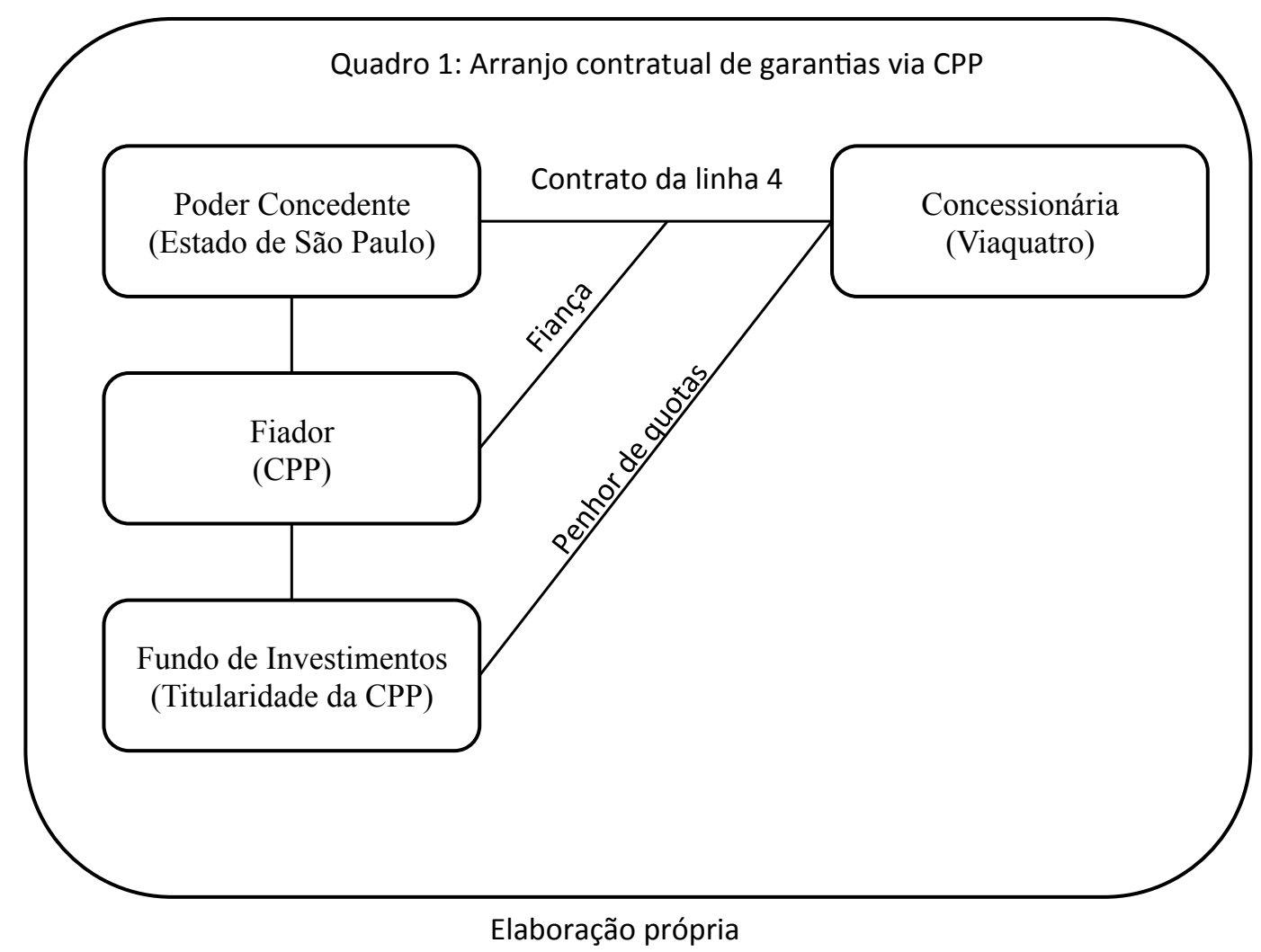

O modelo criado se mostrou interessante para o parceiro privado na medida em que: (a) envolvia uma empresa estatal, com possibilidade de disposição patrimonial $^{72}$; (b) se fundava em garantia real, prescindindo da discussão sobre existência de direito creditício no caso de inadimplemento ou de aplicação de multa; e (c) se constituiu com base em ativos de alta liquidez e não "defasáveis" face o reajuste das obrigações garantidas.

Trata-se de uma interessante articulação de instrumentos jurídicos para atingir os objetivos da política em questão. No entanto, o verdadeiro desafio jurídicofinanceiro seria garantir o recebimento das tarifas, conforme narrado nos dois tópicos seguintes.

72 "Entrevistado 4: Só funciona porque é uma empresa estatal né.

Entrevistador: Aí que tá, meu ponto é bem esse, como ela está no meio do caminho.

Entrevistado 4: Porque ela tem liberdade pra gerir o seu patrimônio. Essa é a grande diferença.” 


\subsubsection{2 - Diferenciação Tarifária: Separando o Contrato da Política}

A linha 4 do metrô de São Paulo passou a integrar o sistema de transportes urbanos metroviários da rede metropolitana. Seu traçado contemplou estações de conexão com a CPTM e o MetroSP, além de todas suas estações estarem ligadas a corredores e faixas exclusivas de ônibus, o que a levou a ser tida como uma linha integradora. ${ }^{73}$

Por essa razão, embora fosse tecnicamente possível inserir mecanismos de cobrança diferenciada, como barreiras entre as ligações de estações e outras soluções, decidiu-se ${ }^{74}$ que a linha 4 seria efetivamente parte do sistema metroviário urbano e, assim, seu funcionamento tarifário, para os usuários, seria o mesmo do sistema: a tarifa paga pelo passageiro seria a mesma das demais linhas e não haveria cobrança adicional por conexões.

Mas, se o concessionário é remunerado ${ }^{75}$ por contraprestações, por tarifas pagas pelos usuários e por demais receitas alternativas, complementares e acessórias que possa gerar autonomamente com o empreendimento, como equacionar a questão de política social da definiç̧ão do valor da tarifa vis a vis a questão de planejamento e viabilidade financeiros do concessionário?

As manifestações sociais iniciadas em São Paulo em junho de 2013 (comumente referidas como "jornadas de junho") deixam clara a sensitividade política da alteração tarifária em transportes públicos nos grandes centros urbanos brasileiros.

Em termos práticos, o problema ao desenhar o modelo da linha 4 era: como, ao se decidir que a tarifa paga pelo usuário não será aumentada de $\mathrm{R} \$ 3,00$ para

\footnotetext{
${ }^{73} \mathrm{~A}$ obrigação de integração de modais também estava prevista na aprovação do projeto para o contrato de financiamento com o BIRD, conforme consta do relatório de investimento do Banco (BANCO MUNDIAL, 2012a).

${ }^{74}$ Entrevistado 2: "Isso foi uma premissa política, o usuário que entrar na linha 4 não pode pagar nem mais nem menos daquele que entrar na linha 2 , inclusive por conta das contingências de integração. Se a linha ficar mais cara, como vai fazer esse processo de integração? Você vai estabelecer linhas de bloqueio para tarifar essa integração? E quando o sujeito entrar na mais cara, ele recebe um reembolso? Era impossível, operacional e politicamente."

${ }^{75}$ Conforme o artigo $2^{\circ}$ da lei 11.079/2004: "Art. 2o Parceria público-privada é o contrato administrativo de concessão, na modalidade patrocinada ou administrativa.

$\S 1$ o Concessão patrocinada é a concessão de serviços públicos ou de obras públicas de que trata a Lei no 8.987, de 13 de fevereiro de 1995 , quando envolver, adicionalmente à tarifa cobrada dos usuários, contraprestação pecuniária do parceiro público ao parceiro privado.
} 
$\mathrm{R} \$ 3,20$, em junho de 2013, o governo estadual pode assegurar que essa decisão política não impactará na remuneração do concessionário que é, por lei, composta pela tarifa?

A solução foi adotar uma diferenciação das tarifas. Há uma "tarifa política", aquela paga pelo usuário para acessar o sistema e usar o serviço, e há uma "tarifa contratual", a que o concessionário faz jus por cada passageiro transportado. ${ }^{76}$

Essa diferenciação serviu não só como facilitador da fórmula de reajuste tarifário mas também como equacionador das questões de gratuidades do sistema que seriam um dificuldade adicional. Isto é, a tarifa contratual tem seu reajuste contratualmente previsto e absolutamente isolado da definição da tarifa política (cobrada do usuário para acessar o sistema). Adicionalmente, a existência das gratuidades legais (redução de valor para estudantes, isenção da cobrança de tarifa para idosos e portadores de determinadas enfermidades, entre outras) é, também, considerada uma questão política e, por isso, não afeta o concessionário, que receberá sua tarifa de remuneração por passageiro transportado, independentemente do "tipo" de passageiro.

No termos das cláusulas sexta à nona do contrato da linha 4 (transcritas no Anexo 5), a remuneração consistia em contraprestações e remuneração tarifária, sendo o valor da tarifa contratualmente estabelecido e independente do valor pago pelo usuário para usar o sistema.

Sendo assim, depreende-se das cláusulas acima mencionadas as seguintes características do modelo tarifário e do sistema de pagamentos elaborados: (i) o concessionário recebe por passageiro transportado, independentemente do passageiro efetivamente pagar ou não para utilizar o sistema (isto é, independentemente do passageiro ser beneficiário de alguma redução tarifária ou gratuidade); (ii) o reajuste da tarifa contratual independe de reajuste da tarifa política; ele acompanha, grosso modo, um combinado de índices inflacionários e é afetado em $20 \%$ de sua composição por índices de qualidade do serviço; (iii) o concessionário receberá $100 \%$

\footnotetext{
${ }^{76}$ Entrevistado 5: "Bom, vamos falar um pouco da tarifa, esse é um modelo absolutamente diferente dos demais. Foi criada uma tarifa de remuneração que é totalmente desvinculada da tarifa política. Isso da uma segurança jurídica pro contrato espetacular. Porque, independente das benesses que os eventuais políticos queiram conceder, você tem seu reajuste garantido.”
} 
do valor da tarifa contratual por passageiro exclusivo e 50\% do valor da tarifa por passageiro compartilhado com o MetroSP ou com a CPTM; (iv) a tarifa de remuneração é captada por uma Câmara de Pagamentos comum a todos prestadores de serviços de transporte público da rede e posteriormente dividida entre eles; e (v) o concessionário da linha 4 terá preferência de recebimento das suas tarifas de remuneração face ao MetroSP e à CPTM.

Esclarecidas as questões atinentes à diferenciação tarifária, há de se compreender qual o arranjo institucional concreto que permite que ela seja repassada ao concessionário e não haja déficits para o operador da linha 4 caso se tenha um descompasso entre o valor arrecadado por "tarifas políticas" e o devido à título de "tarifas contratuais".

\subsubsection{3 - O papel das estatais: sistema de pagamentos e o financiamento de projetos}

Como indicado pela descrição do tópico anterior, havia uma grande probabilidade de que os valores arrecadados por meio de "tarifas políticas" pela linha 4 não fizessem frente ao que o concessionário faria jus à título de recebimento de "tarifas contratuais". Em outros termos, havia uma grande probabilidade de que a receita gerada por essa linha de metrô fosse menor que seus direitos creditícios face à Câmara de Pagamentos do Sistema, probabilidade que acabou se concretizando.

Ainda que a definição inicial da tarifa contratual tenha sido estipulada em valor inferior ao da tarifa política ${ }^{77}$, o descompasso de reajuste dos últimos anos e a não afetação daquela às gratuidades são indicativos dessa ocorrência. Embora não seja precisado o exato valor do déficit criado, ele é expressamente citado como fator de descompasso contábil no Balanço Patrimonial de 2013 da Companhia do Metropolitano de São Paulo (MetroSP, 2014), no tópico de "notas explicativas", sob o título "contas a receber". ${ }^{78}$

\footnotetext{
${ }^{77}$ A tarifa contratual, conforme visto na cláusula sexta, foi estabelecida em $\mathrm{R} \$ 2,08$ (dois reais e oito centavos). Um dia após a assinatura do contrato, passou a viger uma tarifa política de $\mathrm{R} \$ 2,30$ (dois reais e trinta centavos). (MetroSP, 2012)

78 "Convênios e contratos A Companhia assinou em 29/11/2006, como interveniente, o contrato de concessão patrocinada para exploração dos serviços de transporte de passageiros da Linha 4 - Amarela do Metrô de São Paulo, da estação Luz até Taboão da Serra, firmado entre o Governo do Estado de São Paulo, Poder Concedente, e a Concessionária Linha 4 do Metrô de São Paulo S.A. A cláusula nona
} 
Portanto, se existia essa possibilidade, como o Estado de São Paulo, face às limitações do precatório (impossibilidade de execução civil de dívidas contratuais contra a Fazenda Pública) e face à inexistência de meios contratuais de garantia da diferença entre receita tarifária (política) e crédito tarifário (contratual), pôde dar segurança jurídica para que o concessionário aceitasse os termos desse contrato?

As limitações não são apenas jurídicas (precatório e ausência de garantias expressamente previstas), são de viabilidade econômica de se garantir esse fluxo de pagamentos ao longo do tempo.

Em um rápido exercício hipotético simplificado, supondo-se 292 “dias equivalentes" ${ }^{\text {,79 }}$, com uma média de 750 mil passageiros por dia (fluxo de passageiros da fase I, a estimativa para a fase II é de 1 milhão), gerando uma receita tarifária de $\mathrm{R} \$ 1,04$ (tomando por base que todos seriam compartilhados, para gerar um cenário conservador) e considerando-se o prazo contratual de 30 anos, chegar-se-ia à necessidade de se garantir contratualmente o pagamento de $\mathrm{R} \$ 6.832 .800 .000,00$ (seis bilhões, oitocentos e trinta e dois milhões e oitocentos mil reais, calculados a valor presente à data da celebração do contrato).

Como, então, o concessionário se sentiu seguro o bastante de que receberia, diariamente e sem necessidade de execução judicial, os valores contratualmente estabelecidos?

do contrato determina que os pagamentos devidos à Concessionária a título de Receita Tarifária serão realizados através da Câmara de Compensação do Sistema de Arrecadação Centralizada das tarifas públicas. Definiu como substituta, durante a fase de implantação do Sistema de Arrecadação Centralizada independente, a Câmara de Compensação do Sistema de Bilhetagem Eletrônica do Bilhete Único, gerenciado pela São Paulo Transporte S.A. - SPTrans, vinculada à Secretaria Municipal de Transportes da Prefeitura do Município de São Paulo. A mesma cláusula estabeleceu que a quota parte dos valores arrecadados rateados entre o Metrô e a CPTM ocorre após a dedução da quota parte da Concessionária. Os efeitos na arrecadação do Metrô e da CPTM tem origem na diferença entre a regra de remuneração dos serviços prestados por essas entidades e a Concessionária da Linha 4 Amarela. Enquanto as empresas públicas recebem a tarifa paga pelos usuários, a Concessionária Privada recebe tarifa de remuneração por passageiro transportado, conforme definido na cláusula oitava do contrato. O descompasso do reajuste das tarifas públicas e da tarifa de remuneração, o pagamento da tarifa de remuneração inclusive dos passageiros gratuitos e a integração livre entre as linhas do Metrô e da CPTM com a Linha 4 - Amarela, somado à prioridade de recebimento da receita tarifária pela Concessionária Privada, gera impacto financeiro para as empresas públicas do sistema metroferroviário. No exercício de 2014 serão desenvolvidos os trabalhos visando o equacionamento do referido descompasso acima mencionado." (METROSP, 2014, p. 5)

${ }^{79}$ Conforme explicado pelo entrevistado 5: "São [aproximadamente] 300 dias equivalentes. No caso da linha 4, são 292 dias equivalentes. Dia equivalente é seguinte: dos 365 dias do ano, você tem 52 finais de semana e 10 feriados; que dá 251 dias úteis. Só que o domingo representa $30 \%$ de demanda de um dia útil correspondente, sábado $40 \%$ e o feriado $30 \%$, quando você pondera isso, dá mais 40 dias úteis equivalentes." 
A resposta é que uma garantia formal para um valor tão alto seria economicamente inviável. No entanto, ela não é necessária caso se consiga estabelecer um sistema de pagamentos líquido e autônomo, como foi previsto na cláusula nona.

Ao estabelecer, na cláusula nona, a arrecadação conjunta do sistema por uma entidade autônoma e, associado à gestão autônoma das receitas da rede de transportes, se conferir o direito de preferência à concessionária da linha 4 para receber seus créditos decorrentes de tarifas contratuais prioritariamente aos demais operadores sobre trilhos, o que se buscou criar foi exatamente um sistema de pagamentos líquido e autônomo a eventuais ingerências estatais, ilustrado no quadro 2, abaixo.

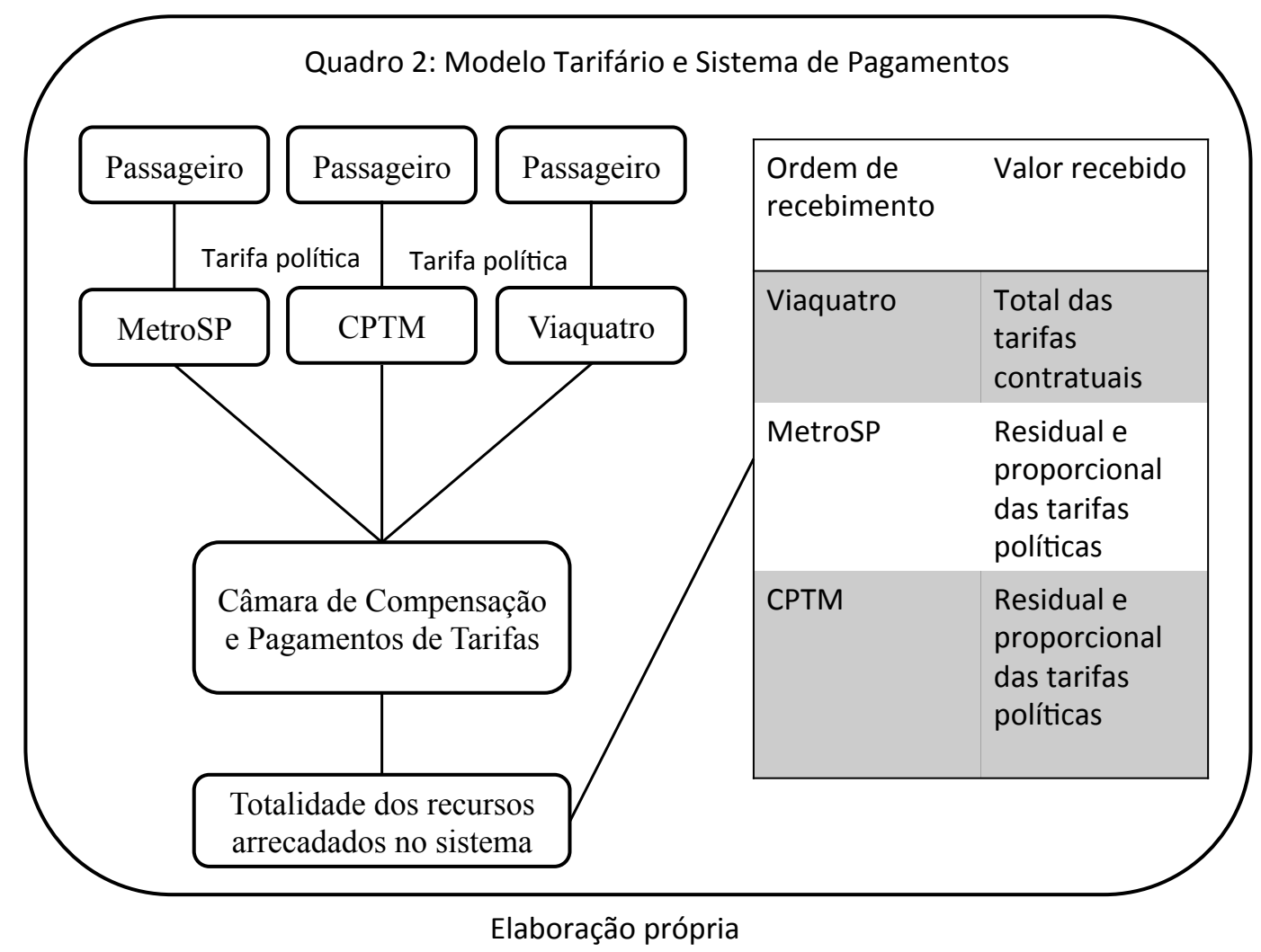

A relevância da criação de um sistema de pagamentos líquido e autônomo (isto é, não pertencente à Administração Direta) foi destacada pelos entrevistados em diversas oportunidades e ficou esclarecida no posicionamento do entrevistado 4:

Entrevistado 4: (...) É o fato de você ter receitas do sistema, segregar essas receitas e vincular parcela dessas receitas para pagar a concessionária. Então, não é uma garantia, é um sistema de pagamentos. 
Entrevistador: É um sistema de pagamentos. É um fluxo de caixa que não corre risco de cair no precatório, caso haja inadimplemento de uma parte.

Entrevistado 4: Não corre o risco e, na verdade, se vincula esse patrimônio ao negócio. Isso, com empresas estatais, funciona muito bem. Então, entidades que tenham receita própria, essa é a diferença. Empresas estatais têm receita própria e prestam serviço.

Entrevistador: E no caso do MetroSP, a tarifa de usuário não pagava a tarifa contratual, por conta das gratuidades e subsídios, só que a Câmara de Compensação recebe do todo né.

Entrevistado 4: A lógica da Câmara de Compensação nada tem a ver com a tarifa do Metrô [tarifa política]. Ela vai servir para pagar a tarifa contratual. É dinheiro para pagar um contrato da Companhia do Metropolitano. Ele tem um contrato, que é o da concessão da linha 4, e esse dinheiro vem das tarifas pagas pelos usuários. Mas o fato da tarifa do usuário não corresponder à tarifa contratualizada, não tem problema algum.

Entrevistador: Porque tem outras linhas que aumentam o "bolo". Tem a CPTM, outras linhas do MetroSP, etc.

Entrevistado 4: Porque a arrecadação [do sistema composto por Companhia do Metropolitano, CPTM e linha 4] é maior do que a despesa com esse contrato. Então, não tem problema. (negritos e grifos feitos pelo autor)

A liquidez do sistema de pagamentos decorre do fato da rede metroferroviária ser composta pela CPTM e pelo MetroSP, além da própria operadora da linha 4. A CPTM possui uma média diária de passageiros da ordem de 2,5 milhões. Já a Companhia do Metropolitano alcança a média diária de 3,7 milhões ${ }^{80}$. Sendo assim, ainda que se considere a possível defasagem da tarifa contratual face à política, bem como a existência das gratuidades, o montante arrecadado pelo sistema é substancialmente superior aos créditos de titularidade da operadora da linha 4, cuja operação giraria entre 750 mil a 1 milhão de passageiros por dia.

Curiosamente, a Câmara de Compensação e Pagamentos, nos termos previstos no contrato, nunca foi implantada. Já havia um sistema implementado de integração tarifária entre os ônibus (concessões de competência municipal) e a rede metroferroviária com a criação do "Bilhete Único" 81 . A solução adotada pelo Estado de São Paulo foi aderir ao sistema e fornecer a preferência da linha 4, de que trata a cláusula nona, nesse sistema. Sendo assim, o sistema (operado pela empresa municipal

\footnotetext{
${ }^{80}$ Dados retirados dos respectivos sites: www.cptm.sp.gov.br e www.metrosp.sp.gov.br .

${ }^{81}$ O "Bilhete Único" foi criado em maio de 2004, conforme noticiado no jornal "Folha de São Paulo" no dia 15/05/2004. (Disponível em: http://www1.folha.uol.com.br/folha/cotidiano/ult95u94221.shtml) No entanto a Companhia do Metropolitano e a CPTM aderiram ao sistema de arrecadação conjunta em 2005, por meio do Convênio n. 023/2005, viabilizando a integração entre modais.
} 
SPTrans), além das operadoras metro-ferroviárias, também coleta tarifas dos ônibus. Os concessionários de ônibus possuem preferência de primeira ordem, seguidos pelo operador da linha 4. O Quadro 3, abaixo, mostra o sistema de pagamentos em funcionamento atualmente.

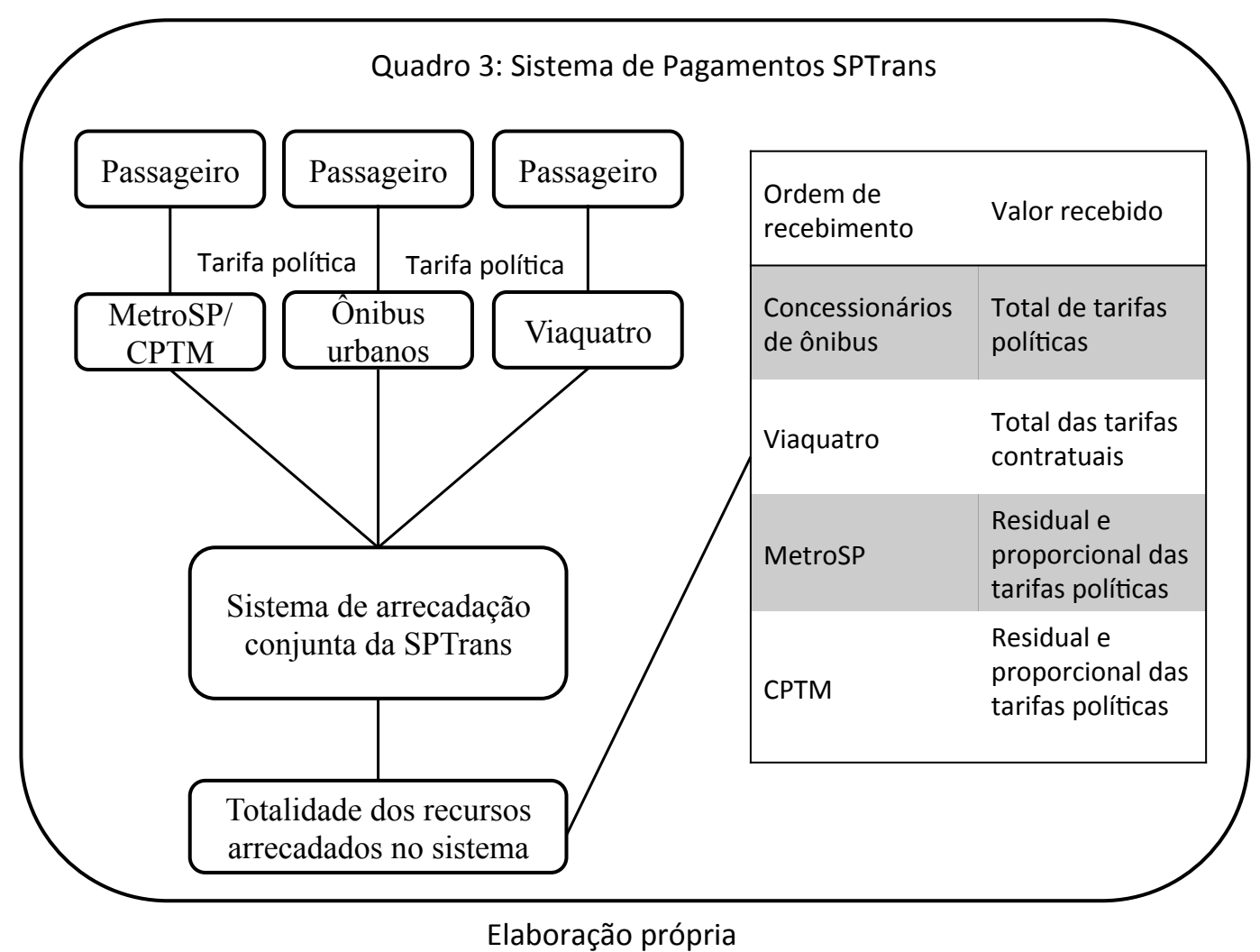

A decisão política de adesão ao sistema já vigente, em substituição ao previsto no contrato, típica escolha sobre instrumentos da ação estatal (LE GALÈS, 2012), foi fortemente influenciada pelo contexto em que estava inserida e pelos arranjos institucionais que a precederam. Tais fatores ressaltam a importância da análise de planejamento e de implementação de reformas institucionais inseridos no contexto, conforme abordado nos capítulos anteriores. Também reforça a ideia de que decisões prévias limitam e moldam a tomada de decisões posteriores e como isso deve ser levado em consideração em análises históricas e institucionais (PRADO e TREBILCOCK, 2009)

\subsubsection{1 - Sistema de Pagamentos e Project Finance}

Da perspectiva teórico-financeira, a relevância do estabelecimento desse sistema de pagamentos reside no fato de que os recursos para a implementação das 
obrigações do parceiro privado, via de regra, são obtidos por meio de project finance $e^{82}$.

No caso em questão, a concessionária da linha 4, a sociedade de propósito específico Viaquatro, obteve, por meio dessa estrutura de engenharia financeira, o financiamento para cumprir suas obrigações contratuais com o Banco Interamericano de Desenvolvimento (BID, 2008).

Finnerty define project finance como

a captação de recursos para financiar um projeto de investimento de capital economicamente separável, no qual os provedores de recursos veem o fluxo de caixa vindo do projeto como fonte primária de recursos para atender ao serviço de seus empréstimos e fornecer o retorno sobre seu capital investido no projeto. (FINNERTY, 1999, p. 2)

Em oposição aos modelos de financiamento que dependem da existência de patrimônio exequível do tomador para gerar a possibilidade de fornecer recursos (funding), o project finance se caracteriza por ser fundado nas qualidades intrínsecas do projeto. Ao invés de exigir uma garantia real para viabilizar o financiamento, os financiadores avaliam o potencial de lucratividade do empreendimento, mais especificamente, sua capacidade de geração de fluxo de caixa contínuo para viabilizar o atendimento ao serviço da dívida. Se essa geração de receitas é previsível, contínua e de longo prazo, cria-se um arranjo contratual em que os financiadores passam a fiscalizar e eventualmente a ter ingerência (possibilidade de assunção da operação, "step-in rights") no projeto para que ele continue a produzir frutos. Trata-se de um modelo de financiamento típico de projetos de grande escala, nos quais o fornecimento de garantias reais seria inviável ou comprometeria consideravelmente a capacidade financeira do tomador.

As características dos projetos de infraestrutura e, especificamente, de metrô são claramente favoráveis à utilização desse modelo. No entanto, um aspecto é crucial: a ininterruptividade da geração de fluxo de caixa.

Os entrevistados 6 e 7 ressaltaram esse aspecto como determinante para obtenção do financiamento:

\footnotetext{
${ }^{82}$ De acordo com o chefe do departamento de transporte e logística do BNDES (o maior financiador dos investimentos em infraestrutura no país), $80 \%$ das operações financiadas pelo banco seguem esta estrutura de engenharia financeira. (VALOR, 2013)
} 
Entrevistado 7: O nosso financiador [BID] topou o esquema do bilhete único, porque o "colchão" [arrecadação total do sistema] pra gente ainda é bem grande, tem folga. E não tem espaço para floating [retenção dos valores arrecadados por determinado período de tempo] nenhum. A SPTrans tira, depois a Viaquatro tira também. Todo dia zera a conta.

Entrevistado 6: Isso garante realmente que não tenha nenhum recurso retido. Isso funciona naturalmente, por um sistema de estimativas e compensações ao final da semana. Todo dia tem uma verba, dessa verba a gente sabe qual é a quota parte da linha 4.

Por essa razão, portanto, a criação do sistema de pagamentos acima descrito foi, na visão dos atores privados, o fator chave para a viabilidade do projeto:

Entrevistador: E o bolo é muito grande, porque tem MetroSP e CPTM. É uma garantia informal. Dentro do contrato, eu identifiquei isso como a maior garantia de fluxo de caixa que vocês obtiveram.

Entrevistado 5: Exatamente! E nossa tarifa é líquida, é por passageiro transportado. Isso é o melhor dos mundos. (...) A história da Clearing [Câmara de Pagamentos], então, é fundamental. É a primeira coisa que a gente olha.

\subsubsection{2 - Diferenciação tarifária, arrecadação conjunta e a questão da remuneração do concessionário na lei 11.079/2004}

Ao se estabelecer a diferenciação tarifária, a arrecadação conjunta e a preferencia do recebimento dos créditos do concessionário face às empresas estatais, criou-se um arranjo institucional tal que a probabilidade de inexistência de recursos para pagar o concessionário da linha 4 é praticamente nula.

Conforme se demonstrou, e ficou comprovado no balanço patrimonial do MetroSP, a escala da operação dessa empresa estatal e da CPTM, aliada ao fato delas serem controladas pelo poder concedente do contrato da linha 4, implica na possibilidade do "sistema" 83 absorver o impacto financeiro da inadequação arrecadatória gerada pelo modelo tarifário do contrato.

Esse impacto poderia ser absorvido pelo mecanismo jurídico da subvenção econômica, ou subsídio tarifário (artigo 35 da lei 9.074/1995 e artigo 12, §3º da lei 4.320/1964). No entanto, não é feita menção a essa questão específica no contrato e a

\footnotetext{
${ }^{83}$ Isto é, o Estado de São Paulo, diretamente ou por meio de suas empresas.
} 
própria disposição do balanço do MetroSP, ao afirmar que "no exercício de 2014 serão desenvolvidos os trabalhos visando o equacionamento do referido descompasso acima mencionado" ${ }^{84}$ indica que a questão não foi, do ponto de vista do direito financeiro, devidamente prevista.

As concessões patrocinadas, nos termos do artigo $2^{\circ}, \S 1^{\circ}$ da lei de PPPs, são aquelas em que os concessionários são remunerados por contraprestação e por tarifas pagas pelos usuários.

Se o Estado de São Paulo absorve o impacto financeiro desse modelo por outros meios que não o formalmente previsto para fins de subsídio tarifário, de alguma maneira criou-se uma nova forma de remuneração do concessionário. É possível até imaginar que essa nova modalidade seja interpretada como "complementação da tarifa do artigo $2^{\circ}, \S 1^{\circ}$ " ou como "contraprestação indireta". Em ambos os casos, a legalidade seria questionável.

O problema que emerge dessa distinção tarifaria aponta dificuldades não existente no modelo concessões comuns. Ele decorre do próprio fato do serviço ser supostamente deficitário e por isso necessitar de complementações orçamentárias estatais. Desse modo, ainda que a constatação tenha sido feita apenas nos contratos de PPP de metrô em São Paulo, os problemas indicados aqui possuem potencial aplicação em outros serviços públicos.

Entretanto, não é o objetivo dessa pesquisa avaliar a legalidade dos instrumentos utilizados nesses contratos, mas sim descrever os mecanismos pelos quais eles se concretizaram. Acredita-se, contudo, que a descoberta é relevante. Ela auxilia a compreensão dos verdadeiros problemas enfrentados pelo administrador público e das soluções jurídicas utilizadas, permitindo melhor compreensão da interação e do papel do direito nessas complexas relações de coordenação públicoprivada. Suas possíveis repercussões políticas serão discutidas ao final do capítulo.

\footnotetext{
${ }^{84}$ 2013METROSP, 2014, p. 5.
} 


\subsubsection{4 - Divisão adequada de riscos: a essência da noção de parceria?}

Uma importante inovação da lei de PPPs foi a possibilidade de efetiva divisão de riscos entre ente público e parceiro privado. Essa permissão transforma substantivamente a racionalidade das concessões patrocinadas quando avaliadas em comparação às concessões comuns.

A percepção do parceiro privado é, efetivamente, de um empreendimento conjunto em que há objetivos públicos e objetivos privados (muitas vezes discrepantes) na prestação de uma atividade de interesse público. A repartição de riscos funcionaria, então, como um estímulo ao poder concedente e ao parceiro privado para a consecução desse interesse. (cf. RIBEIRO, 2011)

Essa perspectiva está por trás das teorias que fundamentaram a adoção desse modelo contratual no Brasil (expostas no capítulo 3). E é interessante notar que ela, de fato, está presente no imaginário dos parceiros privados:

Entrevistado 5: (...)Uma das perguntas que ocorreram na época da licitação era a seguinte: poderia haver contraprestação negativa? Olha só que pergunta interessante. Isso aconteceu na Tamoios também. Isso significa que vira outorga, aí cai fora de PPP e vira concessão. Mas concessão [comum] não tem aquela divisão de riscos né? Na concessão [comum] é "toma que o filho é teu", na PPP divide riscos. (destaques feitos pelo autor)

Nesse cenário, como definir o que se deve repartir e como efetivamente repartir?

Um contrato desse porte envolve uma enormidade de riscos, ainda que não abarcasse realização de obras. No entanto, um risco especial esteve presente nas entrevistas, o risco de demanda. De acordo com os entrevistados 5, 6 e 7, a mitigação dos riscos de demanda foi considerada parte necessária para obtenção de financiamento do setor privado ${ }^{85}$.

O risco de demanda realmente envolve, de acordo com as entrevistas e com a literatura (GRAEFF, 2011), atribuições do parceiro privado e do ente estatal. De um lado, a qualidade do serviço prestado impacta na geração de demanda. De outro, o

\footnotetext{
${ }^{85}$ Novamente, o aspecto de project finance é ressaltado pelos atores privados e tem repercussões no desenho do arranjo contratual. Mitigar o risco de demanda é indispensável à lucratividade do projeto, à geração contínua de receitas.
} 
mercado de transporte público urbano é fortemente influenciado por decisões de Estado, como a definição de rotas de ônibus que possam "concorrer" com a linha de metrô, incentivos ao uso de automóveis, tributação, entre outros aspectos impactam diretamente na demanda pelo transporte metroviário.

$\mathrm{Na}$ ausência de previsão contratual específica, essas questões relativas à atuação estatal que impactam o equilíbrio econômico-financeiro do contrato são solucionadas por teorias de áleas ordinárias e extraordinárias ${ }^{86}$. Essa solução tem o potencial de judicializar a discussão sobre o equilíbrio econômico-financeiro, o que não seria atrativo ao setor privado e envolveria riscos para ambas partes ${ }^{87}$.

A solução foi equacionada a partir da criação de um sistema de "bandas" (também referido nas entrevistas como "colchão de demanda"), estabelecido nos termos da cláusula décima-primeira (subitens 11.1.4 a 11.1.9, vide Anexo 5).

Com base na demanda projetada, presente nos anexos do edital e cujos estudos estavam disponíveis para verificação, uma variação de 10\% (para cima ou para baixo) seria de risco integral do concessionário. A partir desses níveis, até os limites, mínimo e máximo, de $60 \%$ e $140 \%$ respectivamente, criou-se fórmulas específicas de compensação de parte a parte para cada intervalo de $10 \%$ de variação, constatada trimestralmente. Grosso modo, se a demanda efetiva fosse inferior a $90 \%$ do projetado o estado arcaria com parte dos prejuízos e se fosse superior a $110 \%$, o parceiro privado compartilharia parte dos lucros excedentes. Caso a demanda efetiva superasse os limites de $60 \%$ ou $140 \%$, operar-se-ia o procedimento de recomposição do equilíbrio econômico financeiro. No quadro 4, abaixo, ilustra-se uma versão esquemática do sistema de "colchão de demanda" do contrato.

Curiosamente, segundo os entrevistados 6 e 7, a demanda projetada inicialmente - previstas nos estudos contatados pelo Poder Concedente e naqueles contratados autonomamente pela licitante - foi consideravelmente próxima da efetiva. Desse modo, as formas de mitigação de riscos de demanda sequer foram acionadas.

\footnotetext{
${ }^{86}$ Por todos, ver Aragão, 2013.

${ }^{87}$ É importante destacar, conforme apontado pelo entrevistado 2, que a indefinição de riscos pode, em última análise, ser contrária aos interesses da administração pública, uma vez que parceiros privados de grande porte possuem maior capacidade jurídica para discutir questões de equilíbrio econômicofinanceiro no judiciário.
} 
Esse fato indica duas questões relevantes para fins de determinação de riscos e de evolução da atuação estatal. Primeiramente, reforça o argumento de que, por se tratar da primeira experiência com PPPs em metrô no Brasil, o edital da linha 4 acabou por oferecer mais garantias e assunção de obrigações pelo Estado do que era efetivamente necessário, do ponto de vista econômico. Em segundo lugar, a constatação da precisão das projeções feitas pelo Poder Concedente, permite que ele atue com níveis mais altos de eficiência ao oferecer (como de fato o fez, vide item 3.2.2.3, abaixo) garantias de acordo com a real necessidade do projeto.

Quadro 4: O "colchão de demanda"

\begin{tabular}{|c|c|}
\hline Situação Verificada & $\begin{array}{c}\text { Consequência Contratualmente } \\
\text { Prevista }\end{array}$ \\
\hline Acima de $140 \%$ da demanda projetada & $\begin{array}{l}\text { Recomposição do Equilíbrio } \\
\text { Econômico-Financeiro }\end{array}$ \\
\hline $\begin{array}{c}\text { Entre } 110 \% \text { e } 140 \% \text { da demanda } \\
\text { projeta }\end{array}$ & $\begin{array}{l}\text { Concessionária compartilha lucros } \\
\text { excedentes com o Poder Concedente }\end{array}$ \\
\hline Entre $90 \%$ e $110 \%$ da demanda projeta & Risco assumido pela Concessionária \\
\hline $\begin{array}{c}\text { Entre } 60 \% \text { e } 90 \% \text { da demanda } \\
\text { projetada }\end{array}$ & $\begin{array}{l}\text { Poder Concedente compartilha } \\
\text { prejuízos auferidos pela } \\
\text { Concessionária }\end{array}$ \\
\hline Abaixo de $60 \%$ da demanda projetada & $\begin{array}{l}\text { Recomposição do Equilíbrio } \\
\text { Econômico-Financeiro }\end{array}$ \\
\hline
\end{tabular}

Elaboração Própria

Por fim, acredita-se que modelo de "bandas" alcança uma aplicação prática bastante ilustrativa da importância de se pensar instrumentos de efetiva repartição de riscos. Ele gera incentivos adequados à busca conjunta do interesse público e minimiza atitudes oportunistas de ambos os lados. 


\subsection{3 - A influência da linha 4 nas contratações futuras}

Para além das questões relatadas como centrais na elaboração do edital e celebração do contrato, a concessão patrocinada da linha 4, conforme narrado nas entrevistas e verificado em documentos oficiais, traz algumas questões relativas à execução do contrato que certamente influenciaram e influenciarão a trajetória de contratações de PPPs em São Paulo e no Brasil.

\subsubsection{1 - Experimentalismo e Aprendizado Institucional}

Inicialmente, é de se verificar que as características principais do modelo desenhado para a linha 4 indicam que ele, de fato, funcionou como um modelo de transição.

O fato de se restringir apenas à operação do serviço e não abranger a construção e operação, apesar de ter sido determinado pelo ambiente institucional da época (inexistência da lei de PPPs à época do financiamento fez com que a obra só pudesse ser realizada nos moldes da lei 8.666/1993) e por condicionalidades do financiamento da obra (forçou a adoção de concessão da operação), deu ao Estado de São Paulo a oportunidade de trabalhar com um modelo moderado. Em outros termos, ao se utilizar a PPP para a operação, se pôde testar novos instrumentos a partir de inovações institucionais graduais, conforme pontuado pelo entrevistado 5 :

Transporte público, sendo o projeto piloto, principalmente os Bancos estavam muito preocupados com a financiabilidade. Os Bancos queriam garantias. Então, mitigação de risco de demanda, está lá; risco cambial, está lá; risco de integração, está lá. Então, eu digo que o edital da linha 4 é o edital dos sonhos de qualquer PPP de transporte público.

A expertise do Estado de São Paulo com as privatizações da década de 90 também contribuiu para a fluidez desse processo de transição. Em diversos momentos, a capacidade desenvolvida para realizar essas privatizações - como corpo técnico financeiro, a experiência com a CPA (Companhia Paulista de Administração de Ativos) ${ }^{88}$, o bom histórico de pagamentos e de cumprimento de contratos de

\footnotetext{
${ }^{88}$ Entrevistado 8: O modelo [de garantias]... também naquela época, a inspiração era o programa de desestatização. O modelo do Estado de São Paulo, que eu acho que é o modelo vencedor, foi inspirado
} 
concessão comum (track record), entre outros aspectos - foi mencionada como elemento facilitador da transição.

Esses fatores mostram que a especificidade de contexto e a análise histórica importam quando se realiza um estudo de natureza institucional. Há fortes indícios, nesse caso, de que o "transplante institucional", conforme preconizado pelos manuais internacionais de boas práticas em contratos público-privados, não seria capaz de produzir os mesmos resultados em ambientes institucionais diversos. Um fator determinante na realidade nacional foi a proeminência de empresas estatais como peças-chave nos diversos níveis de articulação institucional dos arranjos criados, ora como atores do mesmo sistema de transportes e viabilizadoras de fluxos de caixa (MetroSP e CPTM), ora como braços operacionais para fins de desafetação patrimonial e oferta de garantias (CPP), ora como responsáveis pela organização e gestão da arrecadação conjunta do sistema de pagamentos (SPTrans).

A descrição dessas especificidades, portanto, auxilia a melhor compreender quais as reais potencialidades dos atores públicos de coordenação público-privada na economia e quais as dificuldades e alternativas jurídicas brasileiras para a implantação de um modelo de PPPs na prestação de serviços públicos.

\subsubsection{2 - Problemas na Execução: como evitar novos erros?}

Dois problemas se mostraram centrais na implementação da linha 4, ambos relacionados com a integração "obra-serviço".

O primeiro diz respeito ao descasamento temporal da obra com a disponibilização da infraestrutura para a prestação do serviço. Por se tratar de atores diversos, um responsável pela obra e outro responsável pelo serviço, a conexão entre esses dois pontos, como já destacado brevemente nos itens anteriores, foi tormentosa. No entanto, a única alternativa imune a riscos a esse problema seria a adoção do

na CPA do governo Covas para poder fazer a liquidação da dívida do Estado. O modelo da CPP foi inspirado na CPA, que era uma companhia de securitização e eu acho que é o modelo que mais bem funcionou. Funcionou melhor do que o modelo de fundo garantidor da União que até hoje é muito pouco testado, porque a União não fez PPP na verdade. Então, a CPP acabou sendo uma garantia que o mercado tomou. Ou as debêntures, ou os ativos que você já deve ter visto. É a segregação de ativos em uma Companhia de direito privado, portanto a execução é mais fácil, que manejou vários mecanismos de garantia; deu aval [fiança], penhor de quotas e segregou ativos. 
modelo "completo" (obras e serviços privados), já que as demais precauções relativas a garantias de atraso foram tomadas e aceitas pelo mercado.

O segundo ponto é específico ao objeto do contrato. De acordo com as cláusulas primeira e segunda, o objeto da concessão foi a operação do serviço e o fornecimento de material rodante e sistemas de sinalização, de comunicação, de controle e de supervisão.

Já as obrigações do Poder Concedente envolviam, além da obra, o fornecimento de sistemas de energia, telecomunicações, auxiliares (ventilação, escadas, iluminação, etc.), de arrecadação, entre outros.

Essa separação entre os sistemas foi problemática e foi responsável por parte do atraso da abertura das linhas.

Nos termos colocados pelo entrevistado 2:

$\mathrm{Na}$ linha 4 a gente teve um problema de integração muito grande. $\mathrm{O}$ estado fez o sistema de energia e auxiliares e a linha 4 [Viaquatro] a sinalização. (...) na linha 4, energia e auxiliares ficaram com o MetroSP. E os sistemas de Telecom e sinalização ficaram com o setor privado. Na hora de pôr essas coisas para conversar foi muito difícil. Então, você ficou com uma gestão de integração que é sempre assim, você olha para a linha 4 e diz, a culpa não é minha, é da operadora, a operadora diz que é da empreiteira; e o governo fica igual em jogo de tênis, virando de um lado para o outro e paga a conta no final. (...) Tudo que fosse elétrico[deveria ter ficado com o privado]: sinalização, eletricidade, sistemas auxiliares, tudo para o setor privado que compraria.

Por fim, parece ser ponto pacífico que esse foi um erro e que deve ser evitado nas próximas contratações.

A posição do concessionário, já introduzindo o tópico da linha 6 e compartilhando o olhar comparado e "evolutivo" adotado nessa pesquisa, deixa isso claro:

Entrevistado 6: Então, temos dois exemplos em São Paulo que são os seguintes: o da linha 4, que é o da divisão de escopo; e o da linha 6 - um extremo - que é $100 \%$ privado. Como serão as demais, não sabemos ainda. Mas o que a gente sabe é que a linha 4 é um sucesso, [mas] com algumas questões. 
$\mathrm{O}$ que poderia ser melhorado? A obrigação principal da concessionária.

A responsabilidade da interface entre o que o poder público está entregando de obra [com os sistemas de responsabilidade da concessionária] é da concessionária. Nós somos responsáveis pela adequação do sistema à infraestrutura.

Dentro desse conceito, acho que o desenho poderia ter sido melhorado no aspecto que cabe aos sistemas. Eu estou falando, entre outros, em sistemas de portas de plataformas, que eram do escopo do poder concedente e que não tinha como não ter uma interface muito forte com os sistemas da concessionária pela segurança que estava desenhada ali. Os trens são driverless [operados eletronicamente, sem a figura do maquinista no trem] e, para atender às especificações, eles precisam ter um grau de $100 \%$ de segurança. Para o trem poder adentrar uma plataforma, ele precisa se comunicar com as portas de plataforma, todas as portas precisam estar totalmente fechadas para o trem reconhecer que há segurança para entrar na plataforma. E os sistemas são completamente distintos ao extremo, em termos de equipamentos e inteligência do negócio. Tivemos muitas dificuldades nessa integração. Isso foi retardando o projeto, na interface, na homologação, para fazer um posicionamento $100 \%$ seguro de certificação por entidade independente, conforme obrigação contratual. Isso vai fazendo com que o projeto tenha sua deficiência. Esse é um exemplo, mas há outros: ventilação, transmissão de dados, etc. Enfim, essa grande interface de sistemas foi fazendo com que o projeto tivesse um retardamento.

São condições precedentes. Se [o contrato] estivesse em condições diferentes, não digo que pudesse passar totalmente para a concessionária, mas se tivesse sido desenhado de maneira diferente poderia ter minimizado esse impacto.

A descrição dos arranjos institucionais e da arquitetura contratual envolvidos no projeto da linha 4 poderia se estender a inúmeras questões. Diversas cláusulas contratuais e aspectos institucionais desse projeto podem e devem ser analisados em pesquisas jurídicas. Mas, para os fins da presente pesquisa, valendo-se das variáveis de análise estabelecidas no capítulo $1^{89}$ e tomando como norte os aspectos mais relevantes das entrevistas, as partes centrais do caso foram descritas e contextualizadas ao longo desse tópico (3.1). No tópico seguinte, a linha 6 será

\footnotetext{
${ }^{89} \mathrm{O}$ papel das empresas estatais na implementação desse novo modelo de prestação de serviços públicos, as formas de financiamento das obras e dos serviços, os arranjos institucionais construídos para garantir o pagamentos de valores ao parceiro privado e as formas de interação e a forma de realização do diálogo público-privado na construção do desenho institucional dos projetos.
} 
analisada tendo como referência as mesmas variáveis e as discussões realizadas para a linha 4.

\section{2 - Linha 6 - A afirmação do modelo}

\subsection{1 - Características básicas}

Em 18 de dezembro de 2013, o Governo do Estado de São Paulo anunciou a celebração do contrato de concessão patrocinada com o Consórcio MOVE ${ }^{90}$ para fins de construção e operação da linha 6 - Laranja - do metrô. ${ }^{91}$

A linha 6 - também conhecida como "linha das universidades" - já que cruzará regiões próximas à FGV (futura estação 14bis), Mackenzie, PUC e FAAP teve sua importância ressaltada pelo governador Geraldo Alckmin:

"A Linha 6-Laranja será integradora e proporcionará mais sinergia ao transporte metroferroviário. A linha sairá de São Joaquim, passará pelas universidades, cruzará o Rio Tietê e irá até Freguesia do Ó e Brasilândia. Trata-se de uma grande obra." 92

O contrato celebrado entre o Estado de São Paulo e o Consórcio MOVE possui o valor de aporte, contraprestação e investimentos a cargo do concessionário da ordem de $\mathrm{R} \$ 9,6$ bilhões ${ }^{93}$, sendo aproximadamente $53 \%$ do investimento realizados pelo Estado de São Paulo (cobrirá as desapropriações e outros custos de obras, bem como contraprestações pelo serviço prestado) e 47\% (referente aos demais custos de obra e de operação) estão a cargo do concessionário.

\footnotetext{
90 Composto pelas empresas Odebrecht Transport S/A, Construtora Queiroz Galvão S/A, UTC Participações S/A e Fundo de Investimentos Eco Realty.

91 Conforme noticiado, entre outros meios, pelo jornal Estado de São Paulo: http://www.estadao.com.br/noticias/cidades,alckmin-anuncia-linha-6-para-2018-e-fala-de-demora-emobras-do-metro, $1110071,0$. htm

${ }^{92}$ Trecho retirado do site de informações gerais sobre a linha, da Secretaria de Transportes Metropolitanos: http://www.stm.sp.gov.br/index.php/obras/parcerias-publico-privadas-ppp/linha-6

${ }^{93} \mathrm{O}$ valor do contrato, na cláusula quinta, foi calculado computando a estimativa de remuneração por tarifa contratual, o que o elevou a, aproximadamente, R \$23 bilhões. No entanto, se os investimentos públicos forem calculados em termos relativos a esse valor, eles serão artificialmente reduzidos, já que a remuneração por tarifa (que envolve todos os mesmos problemas conceituais apontados na linha 4) não consiste valor de investimento.
} 


\subsection{2 - Evolução institucional e a escolha de instrumentos jurídicos}

A linha 6 consiste em um modelo contratual muito mais ousado ${ }^{94}$ que o utilizado na linha 4. Por isso, surgem algumas dúvidas: qual o motivo da escolha desse arranjo contratual mais complexo? O que, da experiência da linha 4, influenciou as escolhas específicas desse novo modelo?

Para dar continuidade à análise institucional que essa pesquisa pretende realizar, serão destacadas as temáticas centrais do contrato da linha 6 a partir de comparação com a linha 4 .

Nesse sentido, a partir da análise dos documentos públicos e das entrevistas, utilizando-se dessas para "filtrar" os problemas reais dos aparentes, contatou-se que os principais elementos que foram mantidos são: o modelo tarifário (3.2.2.1); a utilização da arrecadação conjunta e a preferência de recebimentos ao parceiro privado no sistema de pagamentos como "garantia" institucional (3.2.2.2); a utilização de mecanismos de divisão objetiva de riscos (3.2.2.3); e o oferecimento de garantias contratuais por intermédio da CPP (3.2.2.4).

Já as diferenças mais marcantes foram: o objeto contratual (construção e operação) (3.2.2.5); a delegação das atribuições expropriatórias (3.2.2.6); realização de aporte financeiro estatal (3.2.2.7) e o desenho do projeto por PMI (3.2.2.8).

\subsubsection{1 - O modelo tarifário}

A respeito do modelo tarifário. $\mathrm{O}$ que se buscou na linha 6 foi, em suma, o mesmo que na sua antecessora: desvincular a tarifária de remuneração do parceiro do aspecto de política social.

As cláusulas sexta e sétima reproduzem a mesma lógica do modelo tarifário e do reajuste previsto na linha 4 .

\footnotetext{
${ }^{94}$ A caracterização do modelo como "ousado" foi feita pelo entrevistado 3 , quando questionado se o contrato da linha 6 era mais complexo: "É um modelo ousado, na verdade. Ousado no sentido de que, de fato, tem que ter um trabalho muito forte de você cumprir com suas coisas e eles com as deles, de parte a parte." A compreensão das dificuldades adicionais desse modelo será construída ao longo do tópico 4.2 e corrobora a visão do entrevistado 3 .
} 
Houve, contudo, a criação de uma forma adicional de remuneração, batizada “remuneração contingente", nos termos da cláusula 52.7, cujo regramento será o mesmo da tarifa de remuneração. A finalidade dessa nova figura remuneratória será discutida no item abaixo, por estar estritamente vinculada ao sistema de pagamentos enquanto garantia institucional.

\subsubsection{2 - Arrecadação conjunta e os limites do sistema de pagamentos como garantia institucional}

Como visto ao longo do tópico 3.1, o sistema de pagamentos foi tido como o principal fator de segurança financeira para os atores privados. A receita gerada pela rede de transportes metropolitanos mitigou consideravelmente o risco de inexistência de recursos para repassar ao parceiro privado à título de tarifa remuneratória.

A mesma lógica foi adotada na linha 6 . As razões foram, também, as mesmas. No entanto, a concessionária da linha 6 encontra-se em posição menos segura que a linha 4, já que receberá seus créditos após o pagamento da Câmara a esta, ou seja, sua prioridade face ao MetroSP e à CPTM é de segunda ordem.

No entanto, a replicação do sistema com o diferencial do operador da linha 6 ter prioridade relativa, isto é, após exercida a da linha 4, não foi o único uso dado ao sistema de pagamentos nesse contrato. Para além de servir como "garantia institucional" do recebimento de tarifas, na linha 6 , o sistema de pagamentos se presta a uma função adicional: garantir o pagamento das contraprestações em caso de inadimplemento da CPP na sua função de fiadora.

De acordo com a cláusula 52.7 (transcrita no anexo 6), havendo contraprestações não pagas pelo Poder Concedente e não cobertas pelas garantais ofertadas pela CPP, cria-se, automaticamente, uma "remuneração contingente". Essa remuneração adiciona $\mathrm{R} \$ 2,00$ (dois reais) por passageiro transportado às tarifas contratuais que o concessionário faz jus e é paga pelo mesmo sistema de arrecadação conjunta, em preferência de recebimento dos créditos tarifários do MetroSP e da CPTM, conforme exposto no quadro 5. 


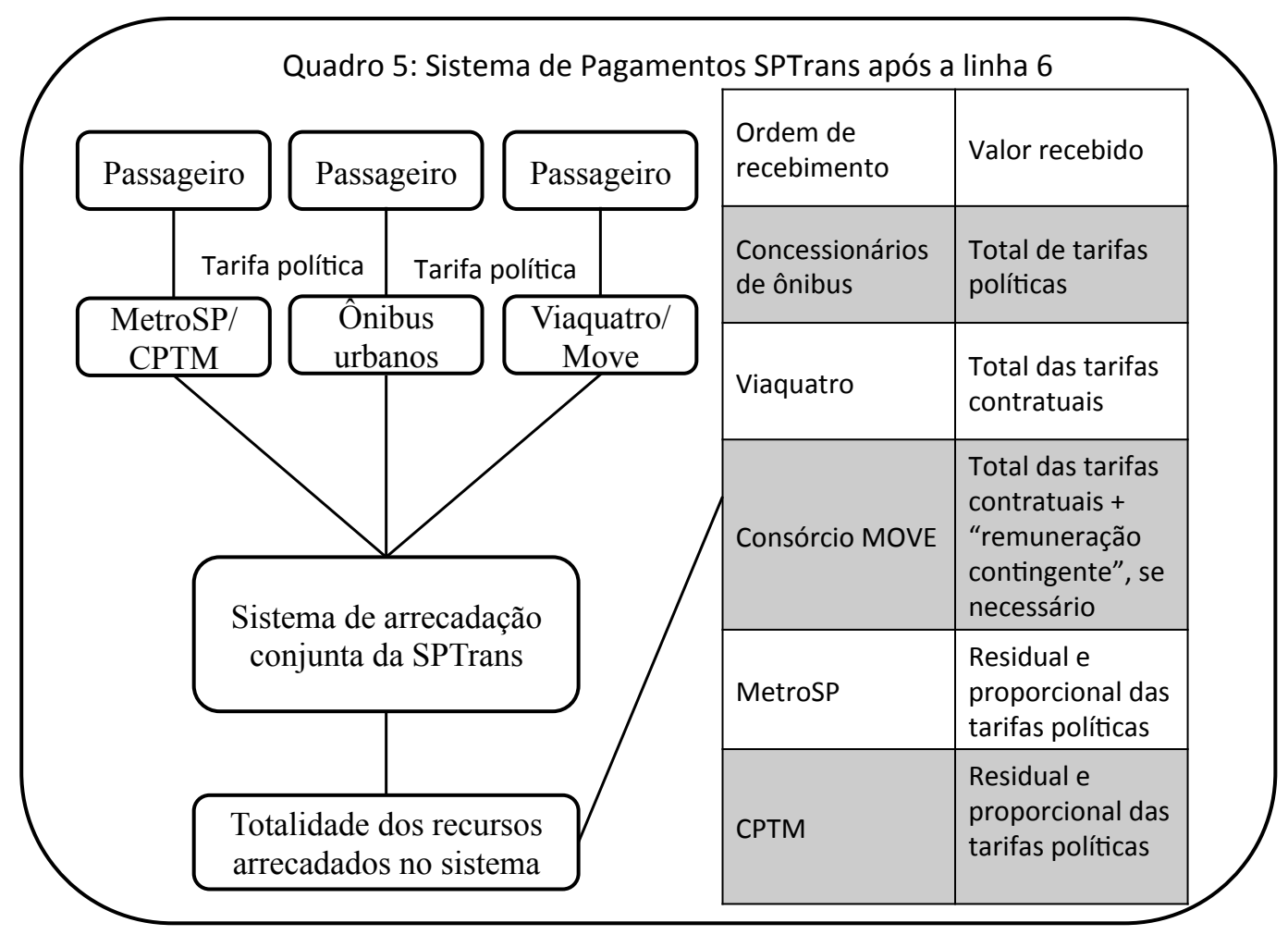

Elaboração própria

Tal dispositivo contratual reforça a visão já presente na linha 4 de que, mais do que um sistema de pagamentos, o arranjo institucional criado para assegurar o fluxo de caixa é uma garantia atípica. Nesse caso específico, tal função garantidora é exacerbada. O sistema de pagamentos é expressamente utilizado como "garantia residual" do recebimento de contraprestações.

Igualmente, a relevância da arrecadação total do sistema fica novamente ressaltada. Por se tratar de empresas estatais com grande operação e que, conforme já afirmado, em último caso serão socorridas pelo Estado de São Paulo, a utilização da oferta de seus "créditos" face ao sistema de arrecadação como uma "garantia" aos concessionários das PPPs é um arranjo que busca alternativas às limitações impostas pelo precatório.

Esse arranjo complexifica e obscurece a gestão financeira das PPPs do Estado de São Paulo. Complexifica, pois cria-se mais uma vez uma forma de remuneração não prevista na lei. Essa nova remuneração possui sua origem nas obrigações estatais de pagar contraprestações, mas seu pagamento se dá pelo sistema criado para gerir as tarifas contratuais. A efetiva definição de valores pagos, da natureza desses pagamentos e da fonte originária desses recursos fica, por esse modelo, ainda mais 
obscura. Ao prever essa nova modalidade de remuneração, cria-se um evidente uso alternativo para as receitas tarifárias, cuja gestão financeira já era tormentosa somente com a linha 4.

De igual forma, ao elevar a importância financeira do sistema de pagamentos, outro aspecto já destacado na linha 4 ganha maiores dimensões na linha 6. A existência de empresas estatais operando o serviço e gerando receitas para o sistema de arrecadação conjunta é ainda mais relevante nesse caso. Também, a importância do papel da SPTrans enquanto gestora autônoma desse sistema, assegurando a não afetação das receitas ao patrimônio de entidades da administração direta, fica ainda mais evidente.

Conclui-se, a partir dessas constatações, que a expansão da utilização de PPPs operada pela celebração do contrato da linha 6, ao aprofundar o modelo desestatizante, reafirma a necessidade de arranjos que envolvam empresas estatais para sua viabilidade jurídica e financeira. Indicando que essa pode ser uma das peculiaridades institucionais do modelo brasileiro de PPPs.

Mais além, a adoção desse sistema de pagamentos para a linha 6 suscita o debate dos limites fáticos desse modelo.

Nesse sentido, o entrevistado 1 explicou com precisão a natureza do problema:

As garantias são finitas. Vai chegar um momento em que, por mais esforço que se faça, você precisará pensar em outra coisa. Pensar como minimizar o risco de comportamentos oportunistas do Poder Público ou de acidentes de percurso no processo orçamentário financeiro do Estado.

Em termos concretos, o entrevisto 7 também elucida a limitação da solução pela Câmara de Pagamentos no longo prazo:

Entrevistado 7: A linha 6 já não tem a mesma qualidade de "garantia", nós somos os primeiros, ainda tem um colchão embaixo. Ela, além de tudo, ainda tem uma contraprestação de 600 milhões que, caso não pague durante um determinado período, a tarifa dela dobra, então ela depende mais do sistema de pagamentos.

Entrevistador: Essa é uma dúvida que eu tenho. Até quando esse modelo vai servir? Na linha 18 ele também foi replicado e o próximo? 
Entrevistado 7: O colchão está pequeno. A CPTM já depende de repasse, falta dinheiro pra ela. O nosso financiador topou o esquema do bilhete único, porque o colchão pra gente ainda é bem grande, tem folga.

De tudo isso pode-se extrair - para fins de análise do "direito em ação" - que a solução do Sistema de Pagamentos, enquanto principal fator de incentivo à confiança dos parceiros privados do efetivo recebimento das tarifas contratuais, possui utilidade marginal decrescente. Sendo necessário, a partir de um momento futuro, pensar em outro modelo que assegure o fluxo de caixa.

\subsubsection{3 - Divisão objetiva de riscos}

Novamente, valendo-se do permissivo da lei de PPPs e efetivando a noção de cooperação público-privada na busca de consecução do interesse público, o contrato previu um rigoroso sistema de divisão de riscos.

No contrato da linha 6, embora na linha 4 tenha havido divisão objetiva de riscos, a questão da devida alocação era muito mais crítica. Como o concessionário é responsável pelas obras, pelas desapropriações para as obras (a ser tratada posteriormente) e pelo serviço, o aumento do escopo de sua atuação, aumentou, também, significativamente os riscos do empreendimento.

Para o entrevistado 8, esse foi o principal ponto do contrato e foi bem solucionado ${ }^{95}$ :

Entrevistador: Quais foram os principais desafios, desde o PMI?

Entrevistado 8: Riscos. Riscos de Engenharia. Como contingenciar e mitigar riscos de engenharia? O que na linha 4 não existiu. Riscos de engenharia compreendem: riscos geológicos, riscos construtivos e riscos de desapropriação.

Porque aí você "quebra" o projeto. Se tem um entrave na execução das desapropriações, elas não se viabilizam, você retarda o fluxo, aumenta o custo e atrasa a receita. Porque essa [linha 6] é greenfield ${ }^{96}$ né? A linha 4 o concessionário comprou o trem, financiou e etc, mas já pegava com um delay [diferença temporal]

\footnotetext{
${ }^{95}$ A questão foi colocada de forma estruturada pelo entrevistado 8, mas também esteve expressamente presente nas falas dos entrevistados 3 e 4 .

${ }^{96}$ Os investimentos são feitos para criar a infraestrutura que vai se operar. Realiza-se a obra em momento muito anterior ao início da geração de receitas.
} 
muito pequeno para começar a operar; a receita começava a entrar seis meses depois; essa aqui [linha 6] são três anos, três anos e meio. Esses eram os grandes desafios.

Entrevistador: Quais foram as soluções?

Entrevistado 8: O arranjo de riscos da linha 6 é realmente um primor. Eu recomendo que ele seja visto com bons olhos porque ele é um arranjo de risco muito ponderado, porque ele foi bem desenvolvido pelo privado e foi bem escrutinado pelo poder público. De modo que tem lá um belo trabalho. E, verdade seja dita, já aproveitando a experiência da linha 4 né? O que deu certo e o que não deu certo. E de outras PPPs de maneira geral.

Então, eu acho que o grande desafio da linha 6 era você colocar uma dimensão de riscos que a linha 4 não tinha, a grande vantagem é que já a partir de um aprendizado de 12 anos. O que ela tem de mais destacável são as soluções que ela deu de equilíbrio para esses riscos: se você tem a trava das desapropriações, como é que você faz para fazer um reequilíbrio que seja fast-track [segue um procedimento específico e mais célere], para não ficar um passivo contratual sendo discutido por dez anos; soluções de risco de obra e de risco geológico, tudo muito bem feito.

(...)

Entrevistador: Você mencionou que toda essa matriz de risco foi bastante escrutinada pelo poder público. Nesse caso, esse escrutínio depende de um conhecimento técnico muito profundo né?

Entrevistado 8: É, mas que eu acho que o Estado tem. O que favorece, hoje, os estado de SP e MG serem vanguardistas e terem várias PPPs é que cada vez menos há uma assimetria de informações entre privado e Estado. Essa simetria de informações, o fato de você ter, no Estado de SP, gente que entende de PPPs até mais do que o privado, porque tem acervo de experiências, por um lado torna o escrutínio mais eficiente e, segundo, dá ao Estado de SP, ao MetroSP, à PGE, segurança [para atuar]. Ele pode ler a proposta apresentada por qualquer particular porque ele tem confiança que ele sabe identificar o que é positivo e interessante para o Estado e o que é cherry picking ${ }^{97}$. Então, o diálogo se torna mais adequado.

A divisão de riscos entre os parceiros está prevista nas cláusulas vigésima e vigésima-quinta do contrato (Anexo 6). A lógica por trás dessa divisão foi a já mencionada alocação de riscos às partes com melhores condições de suportá-los (cf. GRAEFF, 2011). Em resumo, os riscos atribuídos ao Poder Público foram relativos a:

\footnotetext{
${ }^{97}$ Atuação oportunista do parceiro privado, visando buscar somente aspectos proveitosos da parceria com o ente público e do setor de atuação.
} 
procedimentos arqueológicos que eventualmente onerem o contrato, atraso na liberação dos documentos públicos necessários para as desapropriações, realocação de pessoas vulneráveis atingidas pelas obras e custos ambientais não previstos no contrato.

No entanto, o que chama atenção ao se falar da discussão de riscos é menos o resultado e mais o processo de definição das cláusulas. Um problema apontado pela literatura internacional, na elaboração desses contratos, é existência de capacidade institucional para dialogar questões técnicas com o setor privado.

Em igual sentido, a existência de "capacidades institucionais", apontada por Gomide e Pires (2014) como elemento essencial à implementação de políticas públicas no contexto do $\mathrm{NAE}^{99}$, é expressamente reconhecida pelo entrevistado.

Interessante notar que a fala do entrevistado contempla, ao mesmo tempo, os dois aspectos relatados por Gomide e Pires (2014) como constituintes da capacidade institucional, quais sejam: o técnico-administrativo e o político. Conforme os mencionados autores, a dupla dimensão da capacidade estatal (aqui chamada de capacidade institucional) é assim compreendida:

No contexto democrático, entende-se que tal capacidade pode ser entendida a partir de dois componentes: o técnico-administrativo e o político. O primeiro deriva do conceito weberiano de burocracia, contemplando as competências dos agentes do Estado para levar a efeito suas políticas, produzindo ações coordenadas e orientadas para a produção de resultados. O segundo, associado à dimensão política, refere-se às habilidades da burocracia do Executivo em expandir os canais de interlocução, negociação com os diversos atores sociais, processando conflitos e prevenindo a captura por interesses específicos. (GOMIDE e PIRES, 2014, p. 20)

\footnotetext{
98 “Assim, para efeitos deste livro, o conceito de arranjo institucional é entendido como o conjunto de regras, mecanismos e processos que definem a forma particular como se coordenam atores e interesses na implementação de uma política pública específica. São os arranjos que dotam o Estado de capacidade de execução de seus objetivos. Ou, em outras palavras, são os arranjos que determinam a capacidade do Estado de implementar políticas públicas.” (GOMIDE e PIRES, 2014, p. 19-20)

99 "Nesse sentido, o reencontro entre ativismo burocrático e democracia que se verifica atualmente no Brasil suscita uma série de questões. Será possível a um Estado executar políticas desenvolvimentistas e, ao mesmo tempo, proteger direitos e interesses de minorias? Como ampliar a participação dos diversos atores políticos, econômicos e sociais nos processos decisórios e no controle das políticas públicas sem que se produzam ineficiências, distorções ou impasses? Como conciliar as distintas dimensões do desenvolvimento (econômica, social, política, ambiental), respeitando-se os múltiplos interesses dos atores que compõem a sociedade, sem violar liberdades garantidas por um regime pluralista e democrático?" (GOMIDE e PIRES, 2014, p. 16)
} 
Contudo, o aspecto político da capacidade institucional deve abranger mais do que o insulamento à captura estatal por parte de atores privados e a capacidade de diálogo com os agentes de mercado para a coordenação de políticas. Compreende, igualmente, legitimidade democrática do processo decisório, efetivo envolvimento das populações afetadas, entre outros aspectos que parecem estar esquecidos nas falas dos entrevistados ${ }^{100}$ e não foram supridos nos fóruns formais de diálogo com a população (audiência, consulta pública e PMI).

Por fim, vale ressaltar que o mecanismo de mitigação do risco de demanda previsto na cláusula 20.7 foi elaborado com a mesma lógica daquele exposto na linha 4 (tópico 3.2.1.3), sofrendo apenas uma alteração decorrente da maior experiência e confiança nas projeções de demanda. O risco assumido pelo concessionário não mais varia de 90 a 110\% (representando $10 \%$ de variação), mas sim de 85 a $115 \%$ (representando a assunção de variação de 15\%), conforme ilustrado no quadro 6 abaixo.

\footnotetext{
${ }^{100}$ Uma importante ressalva deve ser feita ao posicionamento do entrevistado 2, que se manifestou favoravelmente à elaboração de editais por meio de procedimentos totalmente abertos e democráticos, ao estilo wiki: "A audiência pública é uma bobagem sem fim. É uma perda de tempo e não tem uso prático nenhum. Você vê o sindicato lá fazer a manifestação contra e ficam todos os candidatos olhando um para o outro. Ninguém faz pergunta. E quando faz, o faz de forma anônima. Porque ninguém quer assumir a sua fragilidade. A audiência pública não contribui em nada. Na prática, em nada, ela faz bonito no modelo formal, porque é uma licitação e tal. Mas, na prática, tem uma eficiência muito pequena. (...) Eu acho a consulta pública mais interessante. Eu defendi e, claro, isso não vingou, que a elaboração do edital fosse um mecanismo meio que blogueiro, colaborativo. Ninguém fosse pego de surpresa e também não tivesse o camelô vendendo o $\mathrm{CD}$ com a minuta do edital ali na esquina, sabe? Você atualiza e vai pondo isso num blog, e as pessoas vão colaborando até um dia em que fecha. Mas é aquele modelo que todo mundo sabe que o estado está trabalhando, fazendo reunião, etc. Eu acho que esse seria um modelo de captar a participação privada. Então, a consulta pública funciona porque é uma coisa estruturada, vem [os potenciais licitantes] com escritórios de advocacia e fazem contribuições ponderadas. Diferente da audiência que, você imagina, fazem as perguntas na primeira parte e a gente responde na segunda. Você sabe como eram as respostas? "Não, vide edital." "Não, vide apresentação." É claro, você acha que eu vou me arriscar a falar uma bobagem na audiência pública? Então ninguém explicava nada. Eu gosto do modelo da consulta pública sim. Acho que ele pode ser amplificado com esse modelo que é: a elaboração de edital é pouco, finalizou o documento, vai pro blog e todo mundo faz seu lobby claramente e tudo mais."
} 
Quadro 6: O "colchão de demanda" da linha 6

\begin{tabular}{|c|c|}
\hline Situação Verificada & $\begin{array}{c}\text { Consequência Contratualmente } \\
\text { Prevista }\end{array}$ \\
\hline Acima de $140 \%$ da demanda projetada & $\begin{array}{l}\text { Recomposição do Equilíbrio } \\
\text { Econômico-Financeiro }\end{array}$ \\
\hline $\begin{array}{c}\text { Entre } 115 \% \text { e } 140 \% \text { da demanda } \\
\text { projeta }\end{array}$ & $\begin{array}{l}\text { Concessionária compartilha lucros } \\
\text { excedentes com o Poder Concedente }\end{array}$ \\
\hline Entre $85 \%$ e $115 \%$ da demanda projeta & Risco assumido pela Concessionária \\
\hline $\begin{array}{c}\text { Entre } 60 \% \text { e } 85 \% \text { da demanda } \\
\text { projetada }\end{array}$ & $\begin{array}{c}\text { Poder Concedente compartilha } \\
\text { prejuízos auferidos pela } \\
\text { Concessionária }\end{array}$ \\
\hline Abaixo de $60 \%$ da demanda projetada & $\begin{array}{l}\text { Recomposição do Equilíbrio } \\
\text { Econômico-Financeiro }\end{array}$ \\
\hline
\end{tabular}

Elaboração própria

\subsubsection{4 - A garantia por intermédio da CPP}

A experiência da linha 4 mostrou-se exitosa em fornecer garantias ao parceiro privado por intermédio da CPP. Os fatores determinantes dessa opção foram: a disponibilidade do patrimônio das empresas estatais, a natureza da garantia ofertada (penhor de quotas de Fundo de Investimento) e a liquidez dos ativos.

No caso da linha 6, a experiência se repetiu sem maiores alterações. O único elemento que influenciou uma relação jurídica mais complexa foi o valor da contraprestação.

$\mathrm{Na}$ linha 4, esse valor era, a valor presente, de aproximadamente $\mathrm{R} \$ 75$ milhões. Sendo que a CPP cobriria até R $\$ 60$ milhões. Os valores excedentes estavam descobertos de garantias e dependeriam, em caso de inadimplência, de execução de dívida contratual.

Já na linha 6, as contraprestações alcançam R\$ 606 milhões, divididos em 228 parcelas mensais, gerando uma contraprestação mensal inferior a R 3 milhões. Nos 
termos da cláusula 52.2, a CPP é fiadora somente de até 6 parcelas mensais da contraprestação.

Sendo assim, parte substancial do compromisso financeiro do Estado perante o concessionário não estaria devidamente assegurada. A solução foi conjugar essa utilização de até 6 parcelas com a "garantia residual" dada pela já mencionada cláusula 52.7, que instituiu a "remuneração contingente". Os valores que eventualmente excederem os limites do penhor de quotas do Fundo de Investimentos da CPP, serão garantidos pelo sistema de pagamentos da Câmara de Compensação.

O quadro 7 mostra a função residual conferida ao sistema de pagamentos como garantia do pagamento de contraprestações, quando transmudadas em "remuneração contingencial".

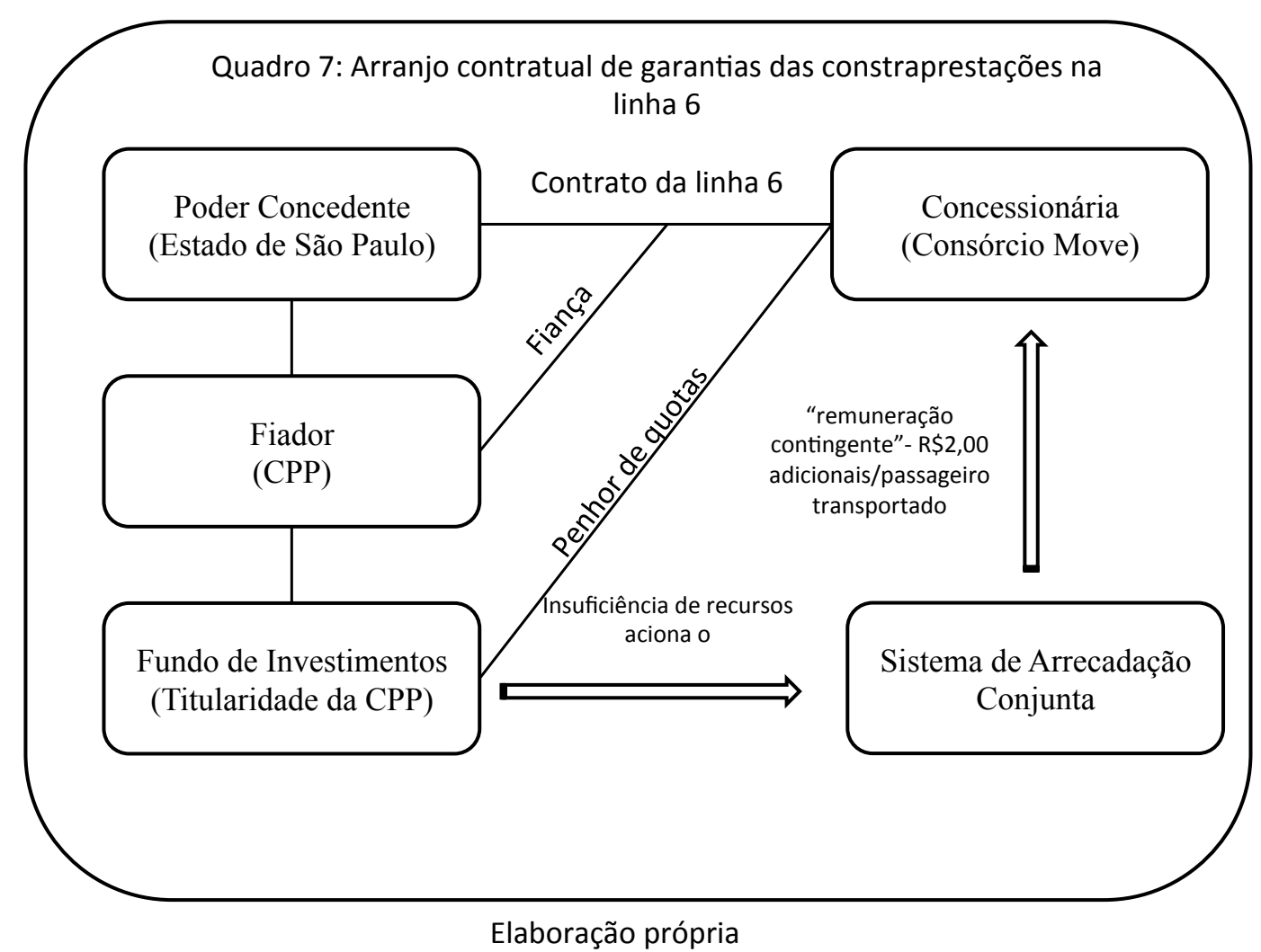

Os potenciais problemas jurídicos gerados por esse desenho contratual já foram abordados no item 3.2.2.2. 


\subsubsection{5 - PPP integral: uma boa opção?}

Os fatores apontados pelos entrevistados como determinantes da escolha pelo modelo integral envolvem: problemas de integração e de adequação temporal (timing) decorrentes da separação do escopo na linha 4, pauta política do governo estadual (principalmente do vice-governador Afif Domingos ${ }^{101}$ ) e possíveis ganhos de eficiência com a integração.

A pauta política do governo estadual e os problemas de adequação temporal e de integração da linha 4 foram pontos consensuais entre os entrevistados. Contudo, esse consenso de motivos não representou convergência de opiniões sobre as alternativas jurídicas.

Para parte dos entrevistados, os problemas contatados pela separação do escopo no contrato da linha 4 , aliados à pauta política, indicavam que a melhor opção era uma PPP integral, envolvendo a totalidade das obras e da operação do serviço.

Para outra parte, essa não era a única alternativa, podendo-se pensar em obras públicas e responsabilidade por todos os sistemas elétricos e operação do serviço para o concessionário. A razão da discordância gira em torno, precisamente, do terceiro ponto: os potenciais ganhos de eficiência trazidos pela obra realizada pelo concessionário.

Como mencionado pelo entrevistado 3, para se realizar as obras de uma linha de metrô, há o necessário subfaseamento e contratação separada de empreiteiras para cada trecho ou estação. A lógica da opção de engenharia é evitar uma dependência entre os trechos que possa atrapalhar o andamento da obra como um todo. Ao se realizar esse tipo de fracionamento das contratações, cria-se um grande número de licitações a serem realizadas e, com isso, custos transacionais elevados a serem suportados pelo Estado, além de mais tempo para a construção da obra.

De acordo com o entrevistado 8, além de transferência de risco, o overprice que é pago ao se "terceirizar" a realização completa das obras refere-se também aos

\footnotetext{
${ }^{101}$ O vice-governador do Estado de São Paulo afirmou ao jornal "Valor Econômico", do dia 15/02/2013, que as linha 2018 do metrô seguiriam o mesmo modelo adotado na linha 6 , e que com a crescente presença de operadores de metrô o Estado de São Paulo pretende criar uma agência reguladora para verificar o cumprimento dos contratos. Disponível em http://www.valor.com.br/brasil/3006272/concessionaria-vai-explorar-estacoes-do-metro-de-sp .
} 
ganhos de eficiência. No modelo de contratações pela lei 8.666/1993 (caso a obra fosse de responsabilidade estatal), há a necessidade de se elaborar projetos básicos, com detalhes que chegam ao nível dos tipos de parafusos. Já no modelo concessões, um dos grandes argumentos favoráveis a sua adoção, é justamente os ganhos de eficiência trazidos pela expertise da iniciativa privada ao poder realizar a obra nos moldes que julgar mais aptos a atingir as finalidades previstas no edital. Nesse modelo, compõem a licitação apenas um anteprojeto de engenharia e elementos do projeto básico, dando margem à atuação privada para moldar esses elementos aos meios mais eficientes que puder encontrar. (cf. RIBEIRO e PRADO, 2011)

De outro lado, os custos e os procedimentos envolvidos na licitação de uma PPP são consideravelmente superiores àqueles de licitações menos abrangentes. Contudo, a escala, em tese justificaria essa escolha política, em termos econômicos. Esse é o posicionamento externado, principalmente, pelos entrevistados 3 e $8^{102}$.

Já o entrevistado 2 se mostrou bastante reticente quanto aos ganhos de eficiência e à economia de tempo geradas pela PPP. Na realidade, segundo ele e

\footnotetext{
${ }^{102}$ Entrevistador: (..) Mas, como as obras de metro são algo extremamente complicado e a linha 4 já mostrou isso, vale a pena o overprice que a gente paga, porque o risco de ter algum problema na obra é quantificado pelo parceiro e ele coloca um over nisso, claro que isso é pensado por vocês, mas como fica isso?

Entrevistado 3: Aí que está, porque você tem que fazer uma conta do overprice. Quanto tempo eu levaria para executar a obra do metro? Quantos atrasos de obra eu suportaria? Quantas licitações eu teria que fazer?

Entrevistador: Tem muitos custos de transação envolvidos aí?

Entrevistado 3: Uma enormidade de custos de transação. Uma linha dessa aqui, em que o concessionário está responsável por todas as estações, pela compra e pela operação. Vocês que são de direito administrativo, faz a conta de quantos contratos eu teria que ter feito para implantar isso via Metro? E não necessariamente cada licitação eu faria pelo menor preço. Licitação é um bicho próprio. Dependendo do que eu estou licitando, em que momento, pode acabar pagando preços ... Então, não dá pra dizer nesse momento, eu precisaria ter o contraditório para dizer o que teria sido, o que foi, etc? Se você pegar a experiência da linha 4 mesmo, que é uma TIR[taxa interna de retorno] mais elevada, etc, mas a linha 4 a implantação da linha a cargo do Metro vai até 2000 e alguma coisa, 10 anos implantando a linha. Então, quer dizer, quanto custa isso? Não sei. Em termos da população ter antes o metro circulando? Mais caro em relação a que? Quais são os custos que a gente está colocando aqui? Se você ponderar tudo isso eu não sei. É um pouco mais caro? É um pouco mais caro olhando friamente se eu fosse fazer direto, mas o custo de oportunidade de estado e tal.

E o aporte, você tem que pensar o seguinte, o aporte é bom para o privado até um limite. Senão ele também não tem taxa. Porque ele ganha na parte dele. Então, um aporte de $90 \%$ vai atrair quem? Só o cara que vai operar, ele não vai ganhar nada. $\mathrm{O}$ aporte tem que ser usado de maneira inteligente. Se for fazer um aporte de $90 \%, 80 \%$ é melhor fazer a obra direto. Do próprio ponto de vista do privado, ele não vai tirar muita margem disso, não tem como dar um ganho de eficiência para o estado, porque fica muito estreita a margem. Nesses projetos que são imensos, de R $\$ 10$ bilhões, você tem margem, mas em outros projetos menores e você dá aporte imenso, não é o modelo de PPP que você vai usar.

Entrevistador: Então, a escala justifica esse tipo de ...

Entrevistado 3: A escala torna viável o modelo contratual. Se você passar para outras escalas, outros players, enfim ...
} 
conforme depreende-se de notícias de jornal da época (ESTADÃO, 2008), em 2008 o governador de São Paulo havia anunciado a ampliação do projeto da linha 6, prometendo o início das obras para 2010 e a entrega da primeira fase da operação já em 2012.

Essa linha, além de ser compromisso político do governador, já vinha sendo estudada e trabalhada internamente no MetroSP. Portanto, o projeto já estava avançado. Ao se optar fazer uma PPP integral, por meio de um PMI, iniciou-se do zero a elaboração do projeto, tendo a licitação sido realizada em 2013 e as obras iniciadas em $2014^{103}$.

Como ressaltou o entrevistado 3, a resposta sobre qual modo de contratação mais eficiente só seria possível de ser obtida se a alternativa a ela tivesse corrido em paralelo. Indicadores da qualidade da escolha pública podem, contudo, ser obtidos a partir da constatação de vantagens e de problemas na execução da obra e na prestação

\footnotetext{
${ }^{103}$ Entrevistado 2: "Na linha 4 a gente teve um problema de integração muito grande. O estado fez o sistema de energia e auxiliares e a linha 4 [o parceiro privado] a sinalização.

E eu, por duas razões, defendia que isso [linha 6 ser feita como PPP integral; construção e operação] não fosse assim. Primeiro, porque a obra de metrô, com túnel escavado, tem uma quantidade de imprevisibilidade infinita. Túnel é um organismo vivo. O projeto executivo de obra de túnel é feito a cada dia um projeto, não tem projeto prévio. Diferente de quando você vai fazer um prédio que o executivo está pronto e você o segue, tendo pequenas alterações, não existe projeto executivo de túnel a priori, porque o túnel é um organismo vivo que reage de forma imprevisível. Claro, você tem um grau de previsibilidade, mas você tem um grau de incerteza imenso nessa obra. Jogar isso para compartilhar com o setor privado vai ser muito caro, não vai sair barato. Dois, para fazer esse modelo, que até então não tinha sido feito, você ia perder muito tempo. E essa era uma linha com um compromisso político grande de entrega, e o estado estava pronto e com dinheiro em caixa.

Também tem isso. Justifica fazer PPP e pagar o custo de transação quando você não tem os recursos. Quanto você tem os recursos, você só justifica fazer PPP pela eficiência da operação, mas aí você joga lá embaixo o investimento do privado que é para pagar a menor taxa possível que é a taxa de financiamento do banco e o custo de oportunidade e os riscos que o privado assume. Por esses argumentos eu era contra.

Tomaram a decisão, entre os secretários, que ia ser PPP integral na linha 6. E eu aproveitei um despacho que eu tinha com o governador e disse: nós estamos cometendo um erro, o MetroSP tenho um projeto pronto, você pode lançar essa obra daqui 3-4 meses, daqui um ano estamos escavando a cidade. Daí o governador ligou pro chefe da casa civil e chamou uma reunião com todos os secretários envolvidos e o vice-governador para tomar a decisão.

Eu me preparei para essa reunião, fiz um arrazoado, com todos os argumentos possíveis, para que a PPP [da linha 6] fosse uma evolução da linha 4. A gente fizesse a obra e contratasse tudo que envolvesse sistemas elétricos, fosse do parceiro privado.

Eu falei para um secretario: nós vamos levar, no mínimo, 6 meses para fazer esse edital. E ele respondeu: 'Imagina, em 2 meses esse edital está na rua. Se o estado de São Paulo levar 6 meses para fazer um edital de PPP, tem que fechar isso aqui.' Isso foi no dia 30 de maio de 2011.

Esse edital saiu em meados de 2012 para o final de 2012. Então, 1 ano e meio que se atrasou a construção de uma linha de metrô desnecessariamente. Muito veio por um temor de que o MetroSP faria uma licitação internacional, e a intenção era essa mesmo. Portanto, as empreiteiras nacionais se viram ameaçadas. E lamentavelmente eu continuo achando que o estado de São Paulo errou. Uma porque jogou uma linha que era para inaugurar em 2016 para 2020, e SP não pode se dar ao luxo de fazer isso com mobilidade urbana"
} 
do serviço. Mas, como esse processo ainda está em curso, a pesquisa limita-se a descrever as diferentes posições, seus fundamentos e as consequências teóricas da escolha do instrumento da ação pública.

A escolha do instrumento PPP-integral, nesse caso, implica a realização de um processo de contratação muito mais complexo. No entanto, limita-se à celebração de um contrato e não de diversos, como seria no regime da lei 8.666/1993.

Ao permitir se "terceirizar" (contract out) a completude do projeto, o contrato de PPP aparece como solução única para vários problemas, na visão de alguns atores. Contudo, deve-se ressaltar que, independentemente das divergências a respeito das repercussões de eficiência econômica, esse modelo se presta a distanciar o Estado das responsabilidades técnicas e políticas a respeito do andamento da obra e do serviço, vinculando-os ao operador. De outro lado, por ter seus interesses devidamente contratualizados, as premissas decorrentes do pacta sunt servanda e do rebus sic stantibus insulam o parceiro privado dos riscos financeiros decorrentes de demandas sociais.

Nesse ponto, fica claro que a opção por esse instrumento - independentemente das razões jurídicas, financeiras, ideológicas e operacionais que estão por trás dela gera efeitos na construção do ambiente institucional que vigorará pelos próximos vinte e cinco a trintas anos. A visão de Le Gales e Lascoumes (2012) de que as alternativas institucionais existem, de que mais de um instrumento pode ser utilizado para a obtenção dos resultados desejados e de que a escolha de diferentes instrumentos impacta diversamente na sociedade que se recria constantemente, a partir da ação pública, é visível, entre outros pontos, nessa decisão.

\subsubsection{6 - Delegação da execução da desapropriação}

A opção feita pelo Estado de São Paulo na cláusula trigésima-sétima foi por delegar os atos executórios dos processos de desapropriação ao concessionário. A racionalidade por trás dessa decisão também foi influenciada pelos problemas de cumprimento de prazos de entrega da obra da linha 4. 
Se a opção estatal pela concessão da obra e do serviço foi, entre outros fatores, motivada pela necessidade de se mitigar problemas de integração e de adequação temporal das obrigações, era necessário se pensar no fluxo completo.

A realização das obras depende da efetivação dos processos de desapropriação dos imóveis afetados. Caso a responsabilidade pelas desapropriações permanecesse com o Poder Concedente, o problema de entrega de condições precedentes apenas seria antecipado, mas não solucionado.

Sendo assim, o sistema de delegação da execução das desapropriações criado na mencionada cláusula envolveu responsabilidades do Poder Concedente de fornecer os documentos e atos preparatórios (inerentes ao seu poder de império) ao concessionário. Adicionalmente, a responsabilidade financeira também seria do Estado. Este pactuou, por meio dessa cláusula, um arranjo tal que o financiamento estatal recebido via BNDES para a realização do projeto seria depositado em contas autônomas e a partir da aprovação dos valores indicados nas desapropriações, a instituição financeira responsável pela guarda dos valores os liberariam para as ações específicas. (mecanismo detalhado no tópico seguinte)

Sobre esse desenho, duas questões específicas precisam ser destacadas.

A ocorrência de atrasos nos atos preparatórios à execução das desapropriações, como fornecimento de documentos por parte do Poder Concedente, entre outras obrigações, foi expressamente prevista no contrato de modo a viabilizar uma "readequação econômico-financeira automática", independente de discussão judicial. A racionalidade desse tipo de escolha é a mesma que justifica a divisão objetiva de riscos, conforme abordado anteriormente. Isolar a concretização dos riscos contratualmente previstos de discussões jurídicas, havendo uma verdadeira antecipação da decisão sobre responsabilidades e valores indenizatórios.

No entanto, deve-se destacar que essa transferência de recursos, para esses fins específicos e da forma que foi feita, foi incidentalmente considerada inconstitucional ${ }^{104}$ em processo judicial e está pendente de recurso no Tribunal de Justiça de São Paulo.

${ }^{104}$ Os argumentos utilizados na sentença do processo n. 1024218-28.2014.8.26.0053, publicada no DJE do Tribunal de Justiça de São Paulo, no dia 05 de setembro de 2014, são no sentido de ilegalidade 


\subsubsection{7 - Aporte financeiro: $o$ ambiente institucional e os instrumentos contratuais}

Até dezembro de 2012, a utilização de PPPs envolvendo obras e serviços em projetos intensivos em capital enfrentava um obstáculo legal: a impossibilidade do parceiro público aportar capital no empreendimento.

Logo, como a contraprestação e as tarifas são remunerações que dependem da prestaçao do serviço ${ }^{105}$, o concessionário tinha que arcar com capital próprio, ou com financiamento adquirido de forma independente, antes de poder obter a remuneração esperada.

Essa estrutura está ligada ao argumento "fiscal" das PPPs: se, entre outros motivos, a razão de se adotar PPPs é trazer capital privado para áreas onde o setor Público não está conseguindo investir como deveria, não faria sentido autorizar que o setor público fosse o responsável por viabilizar, financeiramente, os projetos desde o início.

No entanto, como já mencionado, a lógica de adoção das PPPs no Brasil se deveu a múltiplas razões e o ambiente institucional em que foram inseridas acabou por se mostrar mais complexo do que o simples esgotamento fiscal do Estado.

Sendo assim, em agosto de 2012, foi editada a Medida Provisória 575 de $2012^{106}$, posteriormente convertida - com alterações - em lei em dezembro do mesmo ano (lei 12.766/2012). Esses diplomas normativos instituíram a possibilidade de aporte público, aumentaram o limite da lei de responsabilidade fiscal quanto ao comprometimento dos entes federados com despesas de caráter continuado de 3\%

e inconstitucionalidade da cláusula 37 do contrato de concessão patrocinada $015 / 2013$ por, entre outros motivos, ofensa ao artigo 29 da lei 8.987/1995 e ao artigo 100 da CF. Na visão da juíza do caso, o repasse dessas verbas por mero contrato violaria o regramento de meios jurídicos de disposição de verbas públicas. A sentença aborda, ainda, outros desdobramentos dessa questão, mas parte dessas supostas ofensas legal e constitucional para construir os demais argumentos e embasar a decisão de declaração de ilegalidade do contrato.

${ }^{105}$ Ressalva feita à possibilidade de pagamento de contraprestação por "parcela fruível", anteriormente prevista no parágrafo único do artigo $7^{\circ}$ e agora presente do $\S 1^{\circ}$ desse artigo, ambos da lei 11.079/2004.

${ }^{106}$ A exposição de motivos da MP 575/2012 destacava as justificativas das alterações nos seguintes termos: "A urgência e relevância das medidas, Senhora Presidenta, estão configuradas na necessidade de dar continuidade aos projetos de parceria público-privada e evitar atrasos nas obras a serem contratadas, em especial as do portfólio do Programa de Aceleração do Crescimento - PAC. No âmbito da União, as mudanças no FGP são essenciais para a atratividade dos investidores a vários projetos, entre eles, o Programa de Irrigação do Semiárido Brasileiro - PISA. Já para os entes subnacionais, a ampliação dos limites permitirá a implantação do PAC Mobilidade Urbana em diversos municípios que optarem por PPP." 
para 5\%, e promoveram outros ajustes na legislação com a finalidade de permitir maior comprometimento financeiro estatal com as PPPs.

Curiosamente, as alterações no ambiente institucional ${ }^{107}$ ocorreram entre a finalização do PMI e o lançamento da consulta pública e do primeiro edital de licitação da linha 6. Os dispositivos eram, contudo, aplicáveis imediatamente, inclusive às contratações já em curso.

A versão final do edital de licitação e do contrato contempla o aporte, na cláusula vigésima-sétima, de $\mathrm{R} \$ 4,4$ bilhões face ao valor total de contraprestações de R\$ 606 milhões, demonstrando a representatividade do investimento público e a relevância da alteração legal para o modelo financeiro adotado.

No entanto, se houve a necessidade de orquestração de um complexo arranjo institucional para garantir o pagamento das contraprestações, tanto da linha 4 quando da linha 6 , e se essas sequer representam $20 \%$ do valor desse aporte, como viabilizar uma garantia jurídica eficaz e economicamente factível para o aporte estatal?

Os investimentos estatais compreendidos no aporte da linha 6 advém, em grande parte, de financiamento mediante o BNDES. Logo a solução foi a vinculação dos recursos provenientes desse financiamento a uma conta bancária específica e cuja liberação obedeceria aos termos estipulados no contrato. Blindando, assim, os recursos advindos do financiamento do "risco político" que estariam submetidos caso integrassem formalmente o patrimônio estadual.

A construção desse sistema de pagamentos de aporte, à semelhança do sistema de pagamentos de tarifas, tem a função de garantir uma obrigação sem a necessidade de se constituir garantias formais para tanto. A partir da definição contratual de que as verbas não chegarão a integrar o patrimônio estatal, o

\footnotetext{
107 “Se o ambiente institucional diz respeito às regras gerais que estabelecem o fundamento para o funcionamento dos sistemas político, econômico e social, os arranjos institucionais, por seu turno, compreendem as regras específicas que os agentes estabelecem para si nas suas transações econômicas ou nas suas relações políticas e sociais particulares. Assim, o ambiente institucional fornece o conjunto de parâmetros sobre os quais operam os arranjos de políticas públicas. Estes, por sua vez, definem a forma particular de coordenação de processos em campos específicos, delimitando quem está habilitado a participar de um determinado processo, o objeto e os objetivos deste, bem como as formas de relações entre os atores. Por isto, entende-se que a relação entre as instituições e desenvolvimento não devem se ater ao ambiente institucional, mas, sobretudo, aos arranjos de políticas específicas." (GOMIDE e PIRES, 2014, p. 19)
} 
concessionário fica protegido de inadimplementos e não incorre no risco de receber o aporte por cobrança judicial envolvendo precatório.

Também como o foi no sistema de pagamentos, a saída para a construção do arranjo tido por necessário foi o envolvimento de mais uma empresa estatal. Nesse caso, a utilização da empresa estatal foi menos por razões jurídicas (v.g. possibilidade de disposição patrimonial) e mais por questões financeiras.

Portanto, a maior complexidade da contratação da linha 6 gerou o envolvimento de um número ainda maior de empresas estatais e a construção de arranjos institucionais, cada vez mais elaborados, as envolvendo.

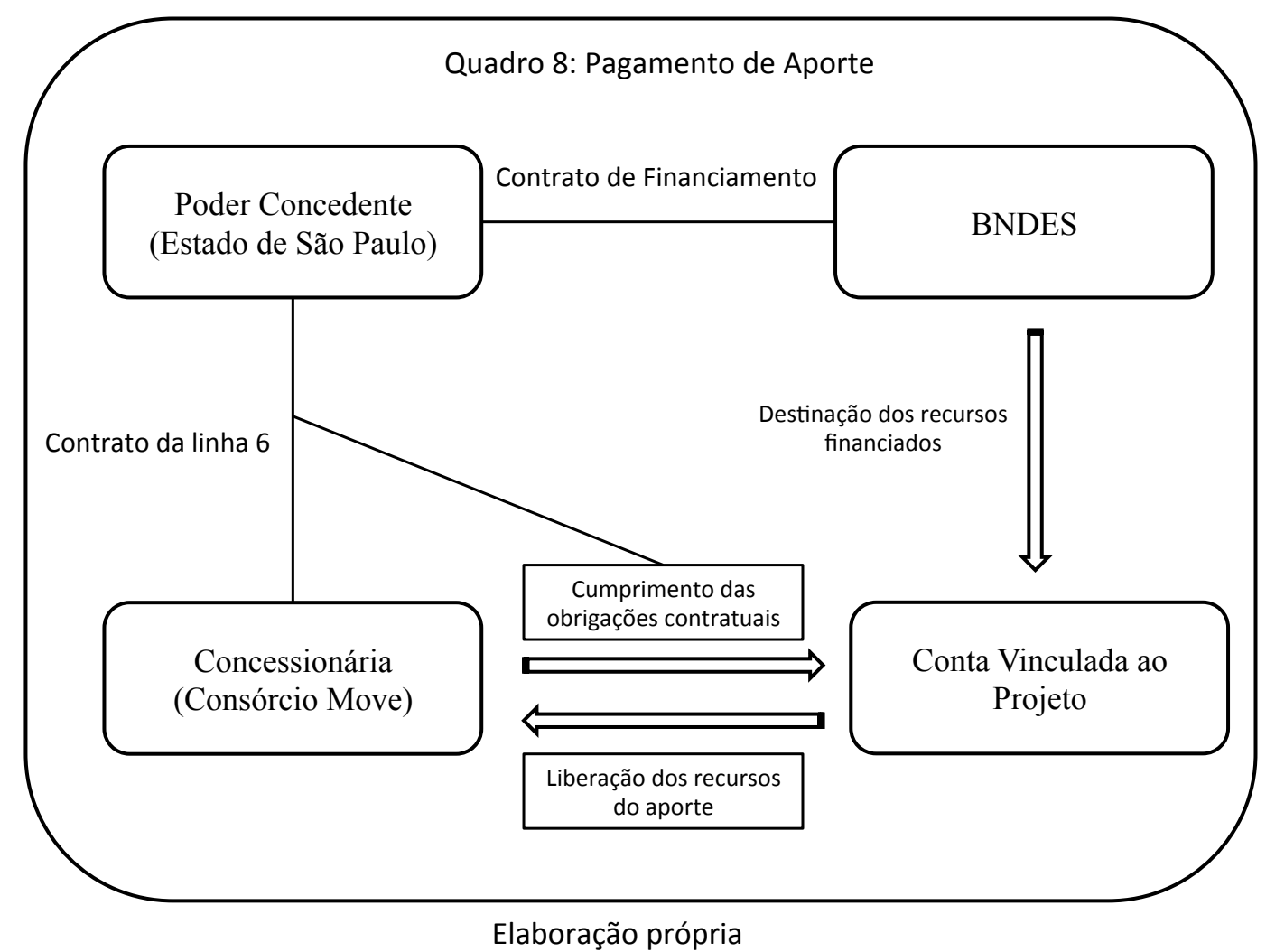

\subsubsection{8 - PMI e diálogo institucional}

Por fim, uma relevante diferença entre as linhas 4 e 6 de metrô em São Paulo foi a forma de elaboração e de modelagem do projeto que deu origem ao edital de licitação. 
$\mathrm{Na}$ linha 4, nos termos descritos ao longo desse estudo, esse processo foi feito pelo MetroSP, PGE, consultores independentes e um consultor financeiro. Já na linha 6 utilizou-se de um instrumento jurídico com grande potencial de incrementar o diálogo institucional, o Procedimento de Manifestação de Interesse (PMI) ${ }^{108}$.

O PMI em questão foi motivado por manifestação prévia de interesse da Odebrecht Transport S/A (OTP) e veio a público com a Chamada n. 1/2011. Seu objetivo era convocar interessados a apresentar projetos de viabilidade para eventual linha de metrô ligando a estação São Joaquim (linha 1 - azul) à região da Brasilândia.

Após o recebimento das propostas, o Estado de São Paulo divulgou, em meados de agosto de 2012, o projeto oriundo do PMI que tomou por base a proposta da OTP, conjugando informações e estudos de outros dois projetos. ${ }^{109}$

Esse projeto, desenhado a partir das propostas da iniciativa privada, mas com conformação estatal conferida pela STM, com auxílio do MetroSP e da $\mathrm{CPP}^{110}$, foi discutido em audiência e em consulta públicas nos meses de setembro e outubro de 2012.

Após o cumprimento dos procedimentos necessários e da adequação de questões específicas pontuadas na consulta pública ${ }^{111}$, o projeto oriundo do PMI deu origem ao edital de concorrência pública internacional n. 1/2012.

Esse edital previu o recebimento de propostas para até maio de 2013. Contudo, devido ao grande número de questionamentos realizados pelas empresas, foi necessária a ampliação do prazo até 31/07/2013, quando a licitação foi considerada deserta (sem proponentes).

\footnotetext{
108 “Uma das estratégias ao dispor do poder público para obter as informações e análises consolidadas nos estudos de viabilidade, a fim de decidir sobre a contratação ou não de uma PPP e a publicação do respectivo edital, é o chamado Procedimento de Manifestação de Interesse (PMI).

O PMI é um instrumento que institucionaliza o diálogo público-privado a respeito de um projeto de interesse público a ser concedido à iniciativa privada. Por intermédio desse instrumento, o setor público obtém, de consultores ou diretamente das empresas interessadas em disputar futuros contratos de concessão, os estudos de viabilidade sobre projetos de infraestrutura que estão na agenda da tomada de decisão do Estado.

Em outras palavras, o PMI é um convite do poder público para que a iniciativa privada interessada possa apresentar, por sua conta e risco, análises e propostas sobre um projeto de interesse público que, no futuro, poderá ser licitado." (PEREIRA et al, 2012, p.6)

${ }^{109}$ Notícia disponível em http://www.pppbrasil.com.br/portal/content/modelagem-final-da-linha-6-dometrô-de-são-paulo-aproveitou-6780-dos-estudos-de-viabilidade- .

${ }^{110}$ Conforme destacado pelos entrevistados 3 e 8.

${ }^{111}$ Conforme documentos disponíveis no site da STM: www.stm.sp.gov.br
} 
Após tal fato, o edital foi republicado em 13/09/2013, com data para apresentação de propostas no dia 31/10/2013 às 14:00 h. Nessa oportunidade, o único licitante interessado foi o Consórcio MOVE que, nos termos da ata de julgamento divulgada em dezembro de 2013, foi considerado apto e sagrou-se vencedor. O contrato de concessão patrocinada n. 015/2013 foi assinado entre o Estado de São Paulo e o consórcio vencedor em 18 de dezembro de 2013.

O contrato celebrado entre o Estado de São Paulo e o Consórcio MOVE tem o valor de R\$9,6 bilhões, sendo metade do investimento realizado pelo Estado de São Paulo (cobrirá as desapropriações e outros custos) e a outra metade (referente aos demais custos de obra e operação) está a cargo do concessionário. O valor inicialmente previsto era de $\mathrm{R} \$ 8$ bilhões, indicando um considerável descompasso com o que foi efetivamente contratado (necessidade de aumento de $20 \%$ ).

Além disso, dos dois trechos de extensão previstos na chamada pública inicial, apenas um (Brasilândia - Bandeirantes) foi mantido no contrato final e somente será construído mediante manifestação de interesse do Estado de São Paulo e celebração de aditivo contratual.

Curioso notar, também, que a empresa OTP está envolvida desde o início no projeto, tendo incitado seu estudo e elaboração, auxiliado a formulação dos projetos técnicos de viabilidade (foi quem mais teve estudos aproveitados no PMI) e integrado o consórcio vencedor. Tal fato indica a possibilidade de ganhos de eficiência e de redução de assimetrias informacionais pelo potencial licitante caso se engaje no projeto desde o início.

A narrativa do histórico que deu origem à celebração do contrato foi feita pelo fato das críticas à utilização do PMI atribuírem a ele a ocorrência da licitação deserta de julho de 2013 e o consequente atraso na contratação da linha 6 .

Para os entrevistados $1^{112}$ e 2, o Estado supôs que por meio do PMI se poderia obter informações de apetite do mercado que foram obtidas com auxílio do consultor na modelagem da linha 4.

\footnotetext{
${ }^{112}$ Entrevistador: Eles supuseram que o PMI resolveria o problema?

Entrevistado 1: Sim, eles acharam que o PMI resolveria o problema, mas depois não resolveu porque saiu uma coisa completamente diferente, o que saiu não era nada do que a iniciativa privada tinha
} 
$\mathrm{Na}$ visão desses atores, o PMI ainda é um instrumento mal regulado e capaz de trazer judicializações desnecessárias ao Estado num futuro próximo. Especialmente, o entrevistado 2 acredita que a efetividade é pequena, os riscos são altos e que o instrumento induz a uma decisão política "capturada" pela ótica privada. ${ }^{113}$

$\mathrm{Na}$ visão desses atores, a solução da linha 4 mostrou-se muito mais adequada do que a tentativa de construção dialogada por meio do PMI. Já outros atores envolvidos no processo, especialmente os entrevistados 4 e $8^{114}$, acreditam que a utilização do PMI - em geral e na linha 6 - é proveitosa.

pensado. A bem da verdade, houve mudança legislativa no meio do caminho, e isso explica porque o PMI começou de uma forma e terminou bem diferente, mas não tinha a figura do advisor. Se você é um player privado e tem um advisor, você vai lá e diz suas necessidades e interesses. Se não tem essa figura, cada competidor fica procurando sua porta, fica um jogo nada transparente.

Entrevistador: São duas coisas diferentes pelo que estou entendendo. Uma coisa é a consultoria para montar um projeto quando não se tem o PMI, outra coisa é a consultoria de mercado?

Entrevistado 1: É, mas normalmente o consultor faz as duas coisas, porque quem propõe o projeto tem a obrigação de vender o projeto que propôs. Não adianta fazer isso separado. E o governo do estado tem uma experiência rica nisso, funcionou exatamente assim no programa de desestatização. Você tinha uma advisor que fazia só a avaliação e outro que avaliava e executava a venda. Esse que fazia a execução tinha que fazer road-show, mobilizar, motivar potenciais compradores.

${ }^{113}$ Entrevistado 2: Eu tenho minhas dúvidas. E eu acho que o Estado, claro deve abrir a possibilidade para PMIs, mas ele precisa dar a direção. Uma coisa é transferir a operação e a construção de uma linha, agora o planejamento do sistema - eu vi PMIs sendo feitas de linhas que não estavam planejadas. Entrevistador: Aí a decisão política recai para quem não é o ator legítimo?

Entrevistado 2:Exatamente. E não tem a visão do todo, tem a visão mercadológica que lhe interessa naquela linha. Então, o Estado tem que ter muito cuidado com isso. Eu sou um entusiasta da parceria do Estado com a iniciativa privada, mas o planejamento da política pública tem de ter uma visão eminentemente pública e a iniciativa tem que ser pública. Porque se o Estado abrir mão disso, aí fecha, fica só com a polícia, exército, e o resto a gente...

É evidente que não vai dar certo, porque você não vai e não pode fazer/planejar uma linha de metrô com a ótica de mercado, o planejamento tem que ser feito com outra ótica. Então, eu [também] acho muito estranho aquele modelo de estruturação jurídica: um valor a ser ressarcido, que ninguém sabe como funciona. Tem uma deficiência legislativa brutal na estruturação das PMIs.

E ainda acho que isso vai dar problema. Ainda acho que um dia o MP vai interceder e vai questionar essas coisas. Como se fixou o valor de R \$10milhões para ressarcir? Qual quais critérios? A gente sabe que não tem um grande detalhamento do valor, até porque não dá pra fazer, esse negócio não tem muito preço. Porquê escolheu esse e não aquele? Como você escolhe $20 \%$ desse estudo e $40 \%$ daquele? É o caso da linha 6.

${ }^{114}$ Entrevistado 8: Funciona melhor; em geral, porque ele é mais célere do que a licitação de um advisor, o chamamento de uma PMI é mais célere, e ele traz uma externalidade positiva que quem apresenta esse projeto - em regra - é alguém que conhece as demandas do mercado e, se o projeto com todos os escrutínios for comprado, o pressuposto é que já tem alguém interessado. Em geral, eu acho PMI melhor do que contratação de advisor.

Entrevistador: Essa ideia do interesse já estar ali contemplado para futura licitação, nesse caso foi até um pouco diferente, porque deu licitação deserta...

Entrevistado 8: Na primeira rodada. Deu deserta, fundamentalmente, porque o pessoal não comprou o que o Metro tinha mudado. O Metro não comprou o projeto, depois como ele foi entregue. Ele se apoiou naqueles estudos, fez recortes demais e mudou coisas que ele achou que tinha melhorar para o estado, com toda a legitimidade. Algumas, inclusive, permaneceram; só que algumas que ele mudou, ele mudou muito drasticamente e aí o mercado não comprou. Mas aí, quando você fez uma segunda rodada, voltando atrás um pouquinho em algumas coisas que ele tinha mudado, o mercado comprou. 
Ambas visões fundamentam-se nos mesmos acontecimentos para dele tirar conclusões diversas. Para além de indicar, novamente, a possibilidade de opções diversas a respeito dos instrumentos da ação pública na tentativa de solucionar o mesmo problema, a realidade é que a experiência e o conhecimento acumulado sobre PMIs ainda são muito restritos, dando ensejo a esse tipo de discrepância.

De todo modo, o que se pode extrair dessa experiência e da regulamentação do instrumento é que ele inaugura um fórum formal de diálogo público-privado que era encarado como uma barreira à construção de projetos cooperativos. A forma como esse diálogo será conduzido dependerá em grande medida da capacidade do Poder Público de lidar com o procedimento.

Esse ponto foi bem esclarecido pelo entrevistado 3, ao falar da sua visão geral sobre o tema e descrever o procedimento da linha 6 :

PMI é um negócio controverso. A experiência internacional tem prós e contras. No caso de São Paulo, o que se fez? Recebíamos uma série de proposições de projetos e se resolveu disciplinar o recebimento. Foi até uma maneira de organizar como receber isso. O que se fez com o decreto [Decreto 57.289/2011 do Estado de São Paulo] foi estabelecer um procedimento. Nesse ponto também é bom, porque aí você canaliza, dá publicidade ao processo, deixa claro que está recebendo, de quem e o que. Nesse ponto tem um efeito positivo. Porque, senão, a maneira de você receber isso é irem os interessados no Secretário e aparecer isso no governo depois.

Sempre existe demanda, demanda legítima de propor projetos e tal. Então, acho que o decreto disciplinava algo que já estava previsto Porque as pessoas, afinal, olham o Estado e é legítimo que elas tenham interesse e capacidade em algumas coisas e proponham.

Então, o decreto procurou disciplinar isso. Preços, reembolsos, fases, sequência e respostas aos projetos. Como São Paulo tem um procedimento bem claro de PPPs, ou seja, o fluxo está bem definido, se estabeleceu um procedimento diferente, que foi esse com PMI, onde se disciplinou a entrada e a análise.

Falando brevemente, a PMI vai funcionar melhor quando se tem capacidade técnica do governo para avaliar o que vem. É simples em algumas áreas. Se recebemos um projeto de metrô ou um projeto de saneamento, o MetroSP e a Sabesp é que vão fazer uma primeira análise, e temos em São Paulo suficiente competência técnica pra avaliar se o projeto faz sentido ou não. Por exemplo, houve dois ou três projetos na área de saneamento em que a Sabesp disse "não, não estamos interessados". 
O próprio Metro, o projeto da linha 20, veio o projeto, depois o Metro se manifestou dizendo em quais condições era interessante, com tal traçado, etc.

Na linha 6, a diferença é que o Metro já estava avançado nisso, já tinha um projeto, já estava trabalhando na linha 6 . Então, aí você contratou o Banco Mundial para analisar especificamente esses projetos de transporte metropolitano, linha 6, linha 18. Eles trouxeram especialistas do banco que olharam o CAPEX, fizeram sugestão de preço internacional. Enfim, certa validação do que foi apresentado.

Sendo assim, acredita-se que o sucesso desse instrumento e dos arranjos institucionais que se desenhem com a sua utilização dependerá das capacidades institucionais do ente estatal para receber projetos e conseguir analisar, em termos técnicos, sua adequação ao interesse público. O sucesso da utilização do instrumento também se relacionará com os mecanismos de conferência de legitimidade democrática ao procedimento de tomada de decisão.

Por fim, a menção ao MetroSP e à Sabesp feita pelo entrevistado, revela, mais uma vez, que a existência de empresas estatais, atuantes em setores específicos, conforma um ambiente institucional propício à elaboração de arranjos cooperativos complexos como os das PPPs.

Para facilitar a compreensão da análise comparativa realizada ao longo desse capítulo, buscou-se sintetizar as principais convergências e divergências contratuais no quadro 9:

Quadro 9 - Diferenças e Similitudes entre os contratos das linhas 4 e 6

\begin{tabular}{|l|l|l|}
\hline & Linha 4 & Linha 6 \\
\hline (a) o modelo tarifário & $\begin{array}{l}\text { Remuneração por tarifa } \\
\text { contratual, diversa da } \\
\text { tarifa política }\end{array}$ & $\begin{array}{l}\text { Remuneração por tarifa } \\
\text { contratual, diversa da } \\
\text { tarifa política }\end{array}$ \\
\hline (b) arrecadação conjunta & $\begin{array}{l}\text { Prevista e se presta a } \\
\text { garantir o pagamento da } \\
\text { tarifa contratual }\end{array}$ & $\begin{array}{l}\text { Prevista e se presta a } \\
\text { garantir o pagamento da } \\
\text { tarifa contratual e, } \\
\text { residualmente, à título de } \\
\text { remuneração contingente, } \\
\text { as contraprestações }\end{array}$ \\
\hline
\end{tabular}




\begin{tabular}{|c|c|c|}
\hline $\begin{array}{l}\text { (c) divisão objetiva de } \\
\text { riscos }\end{array}$ & $\begin{array}{l}\text { Existente e bem } \\
\text { desenhada, destaque para a } \\
\text { mitigação de riscos de } \\
\text { demanda. }\end{array}$ & $\begin{array}{l}\text { Ponto crítico do projeto e } \\
\text { visto como a grande } \\
\text { virtude do contrato, riscos } \\
\text { de engenharia bem } \\
\text { equacionados } \\
\text { reutilização do "colchão } \\
\text { de demanda" }\end{array}$ \\
\hline $\begin{array}{l}\text { (d) garantias contratuais } \\
\text { por intermédio da CPP }\end{array}$ & $\begin{array}{l}\text { Garantia das } \\
\text { Contraprestações por meio } \\
\text { da CPP }\end{array}$ & $\begin{array}{l}\text { Garantia das } \\
\text { Contraprestações por meio } \\
\text { da CPP e, residualmente, } \\
\text { pelo sistema de } \\
\text { pagamentos da } \\
\text { arrecadação conjunta (item } \\
\text { "b") }\end{array}$ \\
\hline (e) objeto contratual & $\begin{array}{l}\text { Fornecimento de sistemas } \\
\text { e operação do serviço }\end{array}$ & $\begin{array}{l}\text { Integral: execução de } \\
\text { desapropriação, realização } \\
\text { da obra e prestação do } \\
\text { serviço }\end{array}$ \\
\hline $\begin{array}{l}\text { (f) delegação das } \\
\text { atribuições expropriatórias }\end{array}$ & Inex & Prevista \\
\hline $\begin{array}{l}(\mathrm{g}) \text { aporte financeiro } \\
\text { estatal }\end{array}$ & Inexistente & $\begin{array}{l}\text { Previsto e garantido por } \\
\text { arranjo contratual via } \\
\text { BNDES e conta vinculada } \\
\text { ao projeto }\end{array}$ \\
\hline (h) desenho do projeto & $\begin{array}{l}\text { MetroSP, CPP, PGE, } \\
\text { Consultor Financeiro e } \\
\text { Consultores Jurídicos }\end{array}$ & $\begin{array}{l}\text { PMI e diálogo envolvendo } \\
\text { MetroSP, CPP, PGE e } \\
\text { BNDES. }\end{array}$ \\
\hline
\end{tabular}

Elaboração própria 


\section{3 - Discussão dos dados - lições e encaminhamentos de pesquisa}

Após um olhar detido sobre os temas tidos por mais relevantes pelos atores envolvidos nesses processos de contratação, acredita-se ser possível: tirar algumas lições da experiência da adoção de PPPs de metrô em São Paulo, destacar as variáveis mais relevantes nesse processo e pontuar problemas que emergem da análise do caso.

Esse tópico será elaborado com base nas conclusões e perguntas extraídas da descrição dos casos ao longo do capítulo. Por isso, sua estrutura é em forma de conclusões parciais e de perguntas emergentes das discussões realizadas.

\subsection{1 - Empresas estatais e a adoção do modelo de PPPs}

Conforme já destacado, a existência prévia de atores estatais (empresas estatais) no mercado em questão, Companhia do Metropolitano de São Paulo e CPTM, viabilizou arranjos institucionais que permitiram que o modelo de financiamento adotado fosse factível.

No entanto, a hipótese aventada no início da pesquisa não dava conta da real relevância das empresas estatais na construção dos arranjos institucionais das PPPs. Mais do que as empresas estatais atuantes no mesmo ramo da concessionária, as estatais estão envolvidas em todos os aspectos críticos das contratações, como auxílio técnico e viabilização financeira ao empreendimento (CPP e BNDES), construção de arranjos capazes de garantir fluxos de pagamentos (SPTrans), entre outros.

Essas constatações indicam a ocorrência de um paradoxo ${ }^{115}$ no modelo desestatizante: a ampliação da participação privada em alguns setores da economia ${ }^{116}$ gera complexidades jurídicas e financeiras que, por vezes, serão solucionadas pelas próprias empresas estatais que o modelo visava a substituir.

Há uma diferença essencial, nesse ponto, da importância das estatais nas PPPs e do papel das estatais nas privatizações dos anos 1990. Nesse movimento, as estatais que foram centrais ao processo eram aquelas que intermediavam as negociações e

\footnotetext{
${ }^{115}$ Certamente, esse paradoxo ainda não é totalmente generalizável, foi constatado em um caso e uma afirmação geral sobre o modelo depende de análises inter-setoriais e ao longo do tempo.

${ }^{116} \mathrm{O}$ “hollowing out of the state”, nos termos de Rhodes (1995).
} 
viabilizavam a "desestatização programada". Já no momento mais recente, justamente por se tratar de relações institucionais mais complexas e de outro modelo de atuação do Estado na economia, com compartilhamento de riscos e investimentos conjuntos, as estatais são parceiras dos empreendimentos in concreto, a continuidade da sua existência é fundamental para a operação das concessionárias e não só para a transferência da atividade ao setor privado.

A interdependência e variabilidade de arranjos cooperativos entre atores públicos e privados para a obtenção dos interesse públicos no setor vai ao encontro da noção de aprendizado institucional proposta por Sabel (2004):

(...) Não há atores no processo ou na visão bootstrapping com esse tipo de visão abrangente. Todos os pontos de vantagem são parciais. Do mesmo modo que os atores privados tipicamente necessitam da ajuda pública para superar limites de informação e problemas de coordenação, os atores públicos que fornecem essa ajuda precisam, eles próprios, da assistência de outros atores, públicos e privados, para superar suas próprias limitações. Ao invés de tentar construir instituições públicas invioláveis cuja perfeição garante, de uma vez por todas, uma igualmente inviolável, mas totalmente privada, ordem de mercado, o processo [bootstrapping ${ }^{117}$ ] visa à corrigibilidade: instituições que, reconhecendo a presunção da perfeição, podem ser - desde o início - reconstruídas, diversas vezes, por combinações em constante alteração de atores públicos e privados, face às mutações das limitações sociais que suas próprias atividades auxiliam a serem enxergadas. (p. 6-7. Tradução própria $^{118}$ )

Dessa forma, a partir da premissa de limitações cognitivas dos agentes e da própria dinâmica de descoberta propiciada pela interação público-privada, mesmo os indícios de esgotamento do sistema de pagamentos via Câmara de Compensação, por exemplo, funcionam como indicadores de aprendizado institucional e servem de base

\footnotetext{
${ }^{117}$ Processo de aprendizado institucional a partir da construção de capacidades próprias, conforme explicado nas citações de Zanatta (2014) no capítulo 1.

${ }^{118}$ No original: "There are no actors in the process or bootstrapping view with this kind of overarching vision. All vantage points are partial. So just as private actors typically need public help in overcoming information limits and coordination problems, the public actors who provide that help themselves routinely need assistance from other actors, private and public, in overcoming limitations of their own. Instead of trying to build inviolate public institutions whose perfection guarantees, once and for all, an equally inviolate, but wholly private, market order, the process view aims for corrigibility: institutions which, acknowledging the vanity of perfectibility the from the beginning on can be rebuilt, again and again, by changing combinations of public and private actors, in light of the changing social constraints on market activity that their activity helps bring to notice." (SABEL, 2004, p. 6-7)
} 
para a construção de novos arranjos envolvendo atores públicos e privados na construção de PPPs.

Em resumo, para além de indicar um traço característico do modelo de PPPs no Brasil, o grande envolvimento das empresas estatais nesse processo pode, também,

indicar que "o modelo brasileiro" é propício a gerar aprendizado e evolução institucionais, isto é, a conformar instituições capazes de se auto-avaliar, transformar e continuar se adaptando a novas realidades e necessidades.

\subsection{2 - Limites e necessidades do modelo de financiamento público-privado}

Os desafios narrados na linha 4 já indicavam que a desestatização dos serviços não financeiramente sustentáveis, de fato, aprofunda e complexifica o modelo de concessões, conforme a narrativa teórica havia sugerido. Aprofunda ao levar o potencial desestatizante a áreas não alcançadas pelo modelo da década de 1990. Já a complexificação ocorre em virtude da necessidade de arranjos institucionais que envolvem mais variáveis do que o simples interesse privado na prestação do serviço e a concessão dessa prerrogativa a ele por meio de um instrumento contratual. Passa a ser necessário se desenhar estruturas que viabilizem divisão adequada de riscos e sistemas de pagamentos líquidos e contínuos.

O caso da linha 6, por envolver investimentos muito mais significativos e um modelo financeiro mais ousado, exacerba essa questão. É preciso criar uma rede de conexões entre entidades estatais, financiadores, concessionárias e outros atores, para dar conta das necessidades de financiamento. $\mathrm{O}$ direito administrativo, e também o constitucional, conformam um ambiente institucional tal que a saída para garantir fluxos de caixa adequados e garantias economicamente críveis por vezes é extremamente custosa e, envolve, invariavelmente, uma ou mais empresas estatais.

$\mathrm{O}$ arranjo institucional criado para garantir o fluxo de caixa e desvincular a tarifa contratual da tarifa política foi extremamente bem sucedido, mas ele aponta uma tendência de exaurimento e novas alternativas deverão ser buscadas. A generalização possível de se elaborar, a partir dessa experiência, é a seguinte: nos 
serviços públicos cuja remuneração tarifária ${ }^{119}$ não advenha completamente de pagamentos dos usuários, o Poder Concedente precisará direcionar receitas juridicamente desimpedidas e com fluxo previsível para viabilizar o financiamento de PPPs.

\subsection{3 - Repercussões axiológicas das escolhas pelos instrumentos jurídicos - a questão da tarifa contratual vs tarifa política}

Ao se separar a tarifa política da tarifa contratual, o que se buscou fazer foi insular as obrigações contratuais do aspecto de política social que perpassa a determinação do valor das tarifas de transportes públicos, que por definição é uma escolha pública sobre subsídios tarifários ${ }^{120}$.

O modelo criado para viabilizar o subsídio, dessa forma, acaba por gerar uma nova modalidade de remuneração pública ao parceiro privado. Seja ele um acréscimo indireto na contraprestação, ou seja, considerado uma complementação de tarifa, em nenhum caso está previsto na lei 11.079/2004, tampouco está a "remuneração contingente" da linha 6. De igual modo, não se enquadram na categoria de subsídio da lei 9.074/1995 e nem poderiam, já que, para fins de segurança jurídica e “cristalização" de posições políticas ${ }^{121}$, é essencial para o concessionário que o sistema mitigue o risco político da (in)definição dos reajustes de tarifas públicas ${ }^{122}$.

Para o parceiro privado, essa definição deve ser contratual e o recebimento dos créditos decorrentes do contrato deve ser independente de execução judicial. Do contrário, a política de subsídios (concedidos nos termos das leis 4.320 e 9.074) poderia ser alterada por decisão política e com isso, culminar, em uma longa discussão judicial ou arbitral sobre reequilíbrio econômico-financeiro. Com o arranjo

\footnotetext{
${ }^{119}$ Não confundir com as outras formas de remuneração em PPP.

${ }^{120}$ Em sentido amplo, não específico da lei 9.074/1995.

${ }^{121}$ Essa discussão tem relevantes repercussões em termos de legitimidade democrática da ação estatal por meio de seus braços operacionais, no caso, as empresas estatais envolvidas na absorção do impacto financeiro. A esse respeito, ver Levi-Faur, 2005 e Raco, 2013.

${ }^{122}$ Uma consideração deve ser feita, nesse ponto. O argumento elaborado aqui não é pela não concessão de subsídios tarifários em transporte público urbano. Ao revés, diversos estudos apontam a regressividade do sistema de apropriação da cidade por meio de transportes privados e as inúmeras externalidades positivas provocadas pela ampliação da utilização de modais coletivos de transporte. As únicas questões que se está a colocar são a respeito do instrumento contratual de diferenciação tarifaria, suas razões de ser e suas consequências jurídico-políticas.
} 
proposto, diferentemente, o equilíbrio será sempre mantido e o recebimento das tarifas está garantido independentemente de medidas judiciais contra a Fazenda Pública.

Novamente há um paradoxo, nesse caso mais aparente do que real. Um subsídio tarifário criado por lei é consideravelmente menos seguro e, por isso, menos atrativo do que o arranjo institucional orquestrado no caso, que envolveu três empresas estatais, contratos privados, um sistema de pagamentos desenhado em um contrato de concessão patrocinada (e não implementado) e a utilização efetiva de outro sistema de arrecadação e pagamentos já em funcionamento ("Bilhete Único").

Por fim, ainda que não seja do escopo desse trabalho avaliar critérios de legalidade da escolha estatal, ao se destacar a ocorrência de uma ferramenta contratual atípica, a presente pesquisa fornece dados para estudos subsequentes avaliarem outros aspectos jurídicos do sistema de remuneração aqui descrito.

\subsection{4 - O que falta ser compreendido?}

Mais do que retirar conclusões, os casos narrados também suscitam dúvidas que não puderam ser respondidas ao longo desse estudo. Portanto, a partir das principais questões decorrentes da discussão dos casos, elaborou-se as perguntas abaixo, que consistem em indicativos de pesquisas futuras. Não se tem a pretensão de respondê-las e sequer se cogita da possibilidade fazê-lo por meio de estudos pontuais, como o presente.

\section{Pergunta 1}

A centralidade do papel das empresas estatais constatada nesse caso representa um indício de mudanças no padrão desestatizante iniciado na década de 199? Seria possível afirmar, a partir de experiências concretas, que a emergência do NAE é responsável por um "deslocamento estrutural" das empresas estatais? Isto é, o NAE é responsável por torná-las peças-chave nas atividades meio de cooperação público-privada inerentes a esse modelo de intervenção do Estado na economia? 
Pergunta 2

Se, cada vez mais, as empresas estatais são usadas como braços operacionais capazes de fornecer flexibilidade jurídica e capacidade técnica à consecução dos objetivos das PPPs e de outras formas de cooperação público-privada, como, no longo prazo, o Estado será capaz de manter centros geradores de conhecimento e capacidades institucionais se a premissa de que se parte é da restrição de sua atuação nos campos específicos (atividades-fim)?

Pergunta 3

Se o modelo de concessões patrocinadas, em grande medida, depende de arranjos concretos com participação de entes estatais e se o isolamento de fluxos de receitas governamentais é finito, haveria um limite para a adoção desse modelo? Em outros termos, haverá um ponto de esgotamento das vantagens advindas da interação público-privada em serviços públicos? Chegar-se-á a um ponto tal que os custos de transação e de oportunidade estatais serão maiores que os benefícios gerados pelas articulações criadas?

Pergunta 4

Em que medida a "desestatização" da gestão dos interesses públicos não torna o Estado, tradicionalmente visto como o principal gestor dos diversos interesses públicos, em um auditor de aspectos técnicos de contratos, expurgando todo debate e confronto políticos do bojo da sua atuação contínua, ao antecipá-los para o momento de celebração do contrato? A contratualização da gestão dos interesses públicos gera, em grande medida, a cristalização (por longos períodos de tempo) de decisões políticas relevantes. Como viabilizar arranjos mais flexíveis, mas ainda assim seguros, que permitam uma gestão democrática desses contratos e confiram legitimidade às escolhas públicas pela utilização desses instrumentos jurídicos? 


\section{CONCLUSÃO}

A pesquisa relatada ao longo dessa dissertação teve como objetivos observar e descrever duas experiências contratuais para, a partir delas, compreender os processos de aprendizado institucional subjacentes à atuação estatal e as formas de utilização dos instrumentos jurídicos em questão.

O estudo dos casos das linhas 4 e 6 de metrô em São Paulo permitiu que se chegasse a uma série de conclusões de naturezas empírica e teórica.

Do ponto de vista empírico, a descrição dos casos permitiu confirmar as hipóteses. Ambas foram concebidas após reformulação do projeto e realização de pesquisas exploratórias para melhor compreensão do campo, o que talvez possa ter influenciado a sua correspondência com os dados verificados na construção dos casos.

A relevância da existência de empresas estatais no ambiente institucional em que se buscou inserir um novo modelo de prestação de serviços públicos ficou patente em diversos momentos da narrativa histórica realizada.

No entanto, como já destacado, acreditava-se que a importância das estatais era restrita ao setor operado pelas concessionárias, isto é, era limitada ao fato de serem operadoras do mesmo sistema e geradoras de receitas que assegurariam o fluxo de caixa da concessionária. Contudo, pôde-se constatar que o destaque das empresas estatais no processo de implantação dessas PPPs é consideravelmente maior. As empresas estatais são elementos centrais da construção de arranjos institucionais relativos a todas as variáveis de análise que perpassam o estudo de caso ${ }^{123}$, demonstrando, portanto, uma relevância consideravelmente maior do que se supunha.

Já a ideia da linha 4 enquanto modelo de transição também foi ratificada pelas escolhas políticas e jurídicas que a sucederam. Sua conformação moderada e a natureza de "teste" conferida pelos agentes estatais aos novos instrumentos jurídicos trazidos em seu contrato corrobora essa visão. A reutilização dos principais instrumentos contratuais na linha 6 , igualmente, confirma essa premissa.

\footnotetext{
${ }^{123}$ Novamente, as variáveis são: o papel das empresas estatais na implementação desse novo modelo de prestação de serviços públicos, as diversas formas de financiamento das obras e dos serviços, os arranjos institucionais construídos para garantir o pagamentos de valores ao parceiro privado e as formas de interação e a forma de realização do diálogo público-privado na construção do desenho institucional dos projetos. Embora o papel das estatais seja uma das próprias variáveis, a sua relevância para as demais não era auto-evidente quando do início da pesquisa.
} 
Também do ponto de vista empírico, ainda que não fosse uma hipótese formal a ser testada, as soluções adotadas nos casos estudados se mostraram consideravelmente mais complexas do que as indicações de modelos jurídicos ideias para adoção de PPPs pela literatura internacional, reforçando a inconsistência da noção de "dotações institucionais" propugnada pelo Banco Mundial ${ }^{124}$.

Nesse ponto, a construção de um modelo brasileiro de PPPs, calcado na cooperação entre empresas estatais de diversos setores e as concessionárias, indica que o mero transplante institucional propalado pelas referidas teorias não daria conta de superar os obstáculos jurídicos e econômicos à implantação das PPPs no Brasil. A via do aprendizado institucional, conforme destacado no item 3.3.1, portanto, se mostra mais adequada à construção de instituições aptas à promoção do desenvolvimento.

Do ponto de vista teórico, a experiência aqui relatada acresce ao corpo de estudos em teoria institucionalista que afirma que as alternativas para o desenvolvimento passam pela construção de arranjos institucionais adequados ao contexto das sociedades em questão. Soluções gerais e alheias às realidades históricas, política e institucional são vazias de conteúdo e potencialmente contraditórias com as reais necessidades contextuais.

Mais do que isso, questões como o papel das estatais e a separação contratual das tarifas levam à conclusão de que as escolhas de instrumentos jurídicos não só solucionam obstáculos à construção de arranjos institucionais operacionais, elas acabam por definir que tipo de compreensão da sociedade será feito no futuro e que tipo de solução poderá ser pensada para essas sociedades ${ }^{125}$.

O direito, assim, passa a ser entendido como alternativa para superação das limitações de uma realidade disfuncional, mas também como determinante dos limites e das potencialidades das realidades futuras. Por isso, a compreensão de seus meandros e engrenagens (i.e. do funcionamento de seus instrumentos) é essencial à tomada de escolha sobre qual sociedade se quer construir.

\footnotetext{
${ }^{124}$ Reforçando argumentos já construídos por, entre outros, Sabel (2004), Santos (2006), Schapiro (2009) e Fabiani (2011).

${ }^{125}$ Os resultados apontam, portanto, para a necessidade de um maior diálogo entre as críticas institucionais aos modelos ortodoxos de desenvolvimento e os estudos sobre o papel dos instrumentos da ação pública (LÉ GALES e LASCOUMES, 2012, por todos), de modo a permitir que se pense a solução para problemas específicos de forma articulada com a estruturação dos ambientes institucionais futuros.
} 


\section{REFERÊNCIAS}

ABRAMOVAY, Ricardo. Entre Deus e o diabo. Mercados e interação humana nas ciências sociais. Tempo Social, 16(2), 2004, pp. 35-64.

ALEM, Ana Cláudia; GIAMBIAGI, Fabio. O BNDES em um brasil em transição. 2010 .

Disponível

em http://www.bndes.gov.br/SiteBNDES/export/sites/default/bndes_pt/Galerias/ Arquivos/conhecimento/livro_brasil_em_transicao/brasil_em transicao_comp leto.pdf, acesso em 26/08/2012.

ALVAREnGA, José Eduardo. Parcerias Público-Privadas: breves comentários. Revista Eletrônica de Direito Administrativo Econômico, Salvador, Instituto de Direito Público da Bahia, no. 2, maio-jun-jul, 2005. Disponível na Internet: $<$ http://www.direitodoestado.com.br>. Acesso em 10/06/2013.

AMARAL, Miguel. Public vs Private managemente of public utilities - The case of urban public transportation in Europe. in Research in Transportation Economics, 22, p. 85-90, 2008.

AMOS, Paul. Public and Private Sector Roles in the supply of transport infrastructure and services: operational guidance for world bank staff. Transport Papers, The World Bank Group, 2004. Disponível em http://www.worldbank.org/transport/, acesso em 11/04/2012.

ANNENBERG, Flávia. Direito e Políticas Públicas: uma análise crítica de abordagens tradicionais do direito administrativo a partir do programa bolsa família. Dissertação de Mestrado. Faculdade de Direito da Universidade de São Paulo. 2014.

ARBIX, Glauco e MARTIN, Scott. Beyond Developmentalism and Market Fundamentalism in Brazil: Inclusionary State Activism without Statism, 2010, disponível em: http://www.law.wisc.edu/gls/documents/paper_arbix.pdf

ARAGÃO, Alexandre S. A evolução da proteção do equilíbrio econômicofinanceiro nas concessões de serviços públicos. In Revista de Direito Administrativo - RDA. V. 263, p. 35-66. Rio de Janerio, 2013.

ARAGÃO, Alexandre S. Direito dos Serviços Públicos. $2^{\mathrm{a}}$ Ed. Rio de Janeiro: Forense, 2008.

BANCO MUNDIAL. Implementation Completion and Results Report. 2012a. Disponível em http://documents.worldbank.org/curated/en/2012/06/16532418/brazil-saopaulo-metro-line-4-project, acesso em 10/06/2013.

BANCO MUNDIAL. Public-Private Partnerships Reference Guide. 2012b. Disponível em http://wbi.worldbank.org/wbi/news/2012/04/10/now-available- 
public-private-partnerships-reference-guide-version-10 , acesso em 10/06/2013.

BANDEIRA DE MELlO, Celso. Curso de Direito Administrativo. 29a Ed. São Paulo: Malheiros, 2012.

BNDES. Informe Infra-estrutura: transporte urbano. 1997. Disponível em http://www.bndes.gov.br/SiteBNDES/export/sites/default/bndes_pt/Galerias/ Arquivos/conhecimento/infra/g7207.pdf, acesso em 10 de junho de 2013.

BORGES, L. F. X.; FARIA, V. C. S. Project finance. Revista do BNDES 18, p. 241280, dezembro de 2002. Disponível em http://www.bndes.gov.br/SiteBNDES/export/sites/default/bndes_pt/Galerias/ Arquivos/conhecimento/revista/rev1808.pdf, acesso em 10/10/2011.

BOVIS, Christopher H. PPP in the Transport Sectors: A framework of engaging the private sector in delivering public services competitively and efficiently. European Public Private Partnership Law Review, n. 70, p. 70-82, 2008.

BRANDÃO, Luiz Eduardo Teixeira; BASTIAN-PINTO, Carlos de Lamare; GOMES, Leonardo Lima; SALGADO, Marina Schuabb. Incentivos governamentais em PPP: uma análise por opções reais. RAE, v. 52, p. 1023, 2012

BRASIL. Cadernos MCidades 6: Mobilidade Urbana. 2004. Disponível em http://www.capacidades.gov.br/media/doc/acervo/5a1566905bdf787cb038552 1af19a938.pdf acesso em 10/06/2013.

BRASILEIRO, Anísio et al. Viação Ilimitada: ônibus das cidades brasileiras. $5^{\mathrm{a}} \mathrm{ed}$. São Paulo: Cultura Editores.

BRESSER-PEREIRA, Luiz Carlos. Do Estado Patrimonial ao Gerencial. In PINHEIRO, Wilhein e Sachs (orgs.). Brasil: um século de transformações. São Paulo: Companhia das Letras, 2002.

BRESSER-PEREIRA, Luiz Carlos. "From old to new developmentalism in Latin America," in Jose Antonio Ocampo, ed. Handbook of Latin America Economics, Oxford University Press, 2009.

CARMONA, Miguel. The regulatory function in public-private partnerships for the provision of transport infrastructure. in Research in Transportation Economics, 30, p. 110-125, 2010. Disponível em http://dx.doi.org/10.1016/j.retrec.2010.10.012, acesso em 10 de março de 2013.

CASTRO, Marcus Faro. Novas perspectivas jurídicas sobre a reforma de políticas públicas no Brasil. Revista de Direito da Universidade de Brasília. v. 1, n. 1. 2014. Pp. 32-64 
COUTINHO, Diogo R. O direito nas políticas públicas. 2012. Disponível em http://www.cebrap.org.br/v2/items/view/766, acesso em 10/06/2012.

COUTINHO, Diogo. Transcrição da participação na mesa de debates 2 "Inovação dos Métodos de Pesquisa em Direito e Renovação da Produção Científica”, realizada no $1^{\circ}$ Encontro de Pesquisa Empírica em Direito. 2011. Disponível em http://reedpesquisa.org/publicacoes/i-eped/, acesso em 03/10/2014.

COUTINHO, Diogo; SCHAPIRO, Mário. Economia Política e Direito Econômico: do desenvolvimento aos desafios da retomada do ativismo estatal. In COSTA, José A. Et al (orgs.). Teoria e Experiência: estudos em homenagem a Eros Roberto Grau. Vol. 1, São Paulo: Malheiros, 2013.

DAVIS, Kevin; TREBILCOCK, Michael J. The Relationship between law and development: optmists versus skeptics. In The American Journal of Comparative Law. Vol. 56, 2008.

DE JONG, Martin; Introducing public-private partnerships for metropolitan subways in China: what is the evidence? In Journal of Transportation Geography 18:2 (2010), 301-313. Disponível em http://trid.trb.org/view.aspx?id=913303, acesso em 10/06/2013.

DELMON, Jeffrey. Understanding options for public-private partnerships in Infrastructure. Policy Research Working Paper 5173, 2010. Disponível em http://elibrary.worldbank.org/content/workingpaper/10.1596/1813-9450-5173, acesso em 10/06/2013.

ECONOMIST INTELLIGENCE UNIT. A recuperação do tempo perdido: o transporte público nas áreas metropolitanas do Brasil. 2011. Disponível em http://www.accenture.com/SiteCollectionDocuments/PDF/Accenture-PublicTransport-Brazil-BrPt.pdf, acesso em 10/06/2013.

EMPLASA. O fenômeno da mobilidade pendular na macrometrópole do Estado de São Paulo: uma visão a partir das quatro regiões metropolitanas oficiais. 2013. Disponível em http://www.emplasa.sp.gov.br/emplasa/RELATORIOPENDULARIDADE-UNICAMP-06-02-2013.pdf, acesso em 10/06/2013.

ENEI, José V. L. Financiamento de Projeto: aspectos jurídicos do financiamento com foco em empreendimento. Dissertação de Mestrado - Faculdade de Direito da USP, 2005.

ENGEL, Eduardo; FISCHER, Ronald; GALETOVIC, Alexander. Soft budgets and renegotiations in public private partnerships. NBER working paper 15300, 2009. Disponível em http://www.nber.org/papers/w15300.pdf , acesso em 7 de agosto de 2013.

ESTADO DE SÃO PAULO. PITU 2025: SÍNTESE. 2006a. Disponível em http://www.stm.sp.gov.br/index.php/planos-e-projetos/sumario-executivo/21planosprojetos/pitu-2025/2114-pitu-2025-sumario-executivo , acesso em 10/06/2013. 
ESTADO DE SÃO PAULO. PITU 2025: PARTE A - Introdução. 2006b. Disponível em http://www.stm.sp.gov.br/index.php/planos-e-projetos/sumarioexecutivo/21-planosprojetos/pitu-2025/2114-pitu-2025-sumario-executivo ， acesso em 10/06/2013.

ESTAdo DE SÃO PAUlO. Apresentação: Linha 6 do Metrô. 2013. Disponível em

http://www.stm.sp.gov.br/images/stories/temporarios/folder_portugues.pdf , acesso em 10/06/2013.

FINNERTY, John. Project Finance: Engenharia Financeira Baseada em Ativos. Rio de Janeiro: QualityMark Editores, 1999.

FURTADO, Clarissa. Se eu perder esse trem... Revista Desafios; 7; 2004. Disponível em http://www.ipea.gov.br/desafios/edicoes/7/artigo12928-1.php , acesso em 10/10/2009.

GAUSCH, J. Luis; LAFFONT, Jean-Jacques; STRAUB, Stephane. Concessions of Infrastructure in Latin America: Government-led renegotiation. 2006. Working Paper disponível em http://idei.fr/doc/by/straub/concessions.pdf , acesso em 07 de agosto de 2013.

GHERSI, Henrique; SABAL, Jaime. An introduction to project finance in emerging markets. Estudio ISEA n. 29. 2006. Disponível em http://servicios.iesa.edu.ve/Portal/EstudiosIESA/An\%20introduction $\% 20$ to $\% 2$ Oproject $\% 20$ finance $\% 20 \mathrm{in} \% 20$ emerging $\% 20$ markets.pdf $\quad$, acesso em $11 / 04 / 2012$.

GOMIDE, Alexandre A. Agenda governamental e o processo de políticas públicas: $O$ projeto de lei de diretrizes da política nacional de mobilidade urbana. IPEA, 2008. Disponível em http://ideas.repec.org/p/ipe/ipetds/1334.html, acesso em 10/10/2009.

GOMIDE, Alexandre A. A regulação dos transportes urbanos, tendências e desafios para o futuro. In: $15 \mathrm{o}$ Congresso Brasileiro de Transporte e Trânsito, 2005, Goiânia. Trabalhos Tecnicos em Eventos da ANTP. São Paulo : ANTP, 2005.

Diponível

em

http://www.cbtu.gov.br/estudos/pesquisa/antp_15congr/pdf/TP-297.pdf acesso em 05/10/2010.

GOMIDE, Alexandre A. Regulação Econômica nos Serviços Públicos de Transporte de Ônibus no Brasil. Tese de mestrado; 1998. Disponível em http://www.scribd.com/doc/17267374/Regulacao-Transporte-ColetivoUrbano-Onibus-1998, acesso em 10/10/2009.

GOMIDE, Alexandre A.; PIRES, Roberto. Capacidades estatais e democracia: a abordagem dos arranjos institucionais para análise de políticas públicas. In GOMIDE, Alexandre A.; PIRES, Roberto. (eds.) Capacidades estatais e democracia: arranjos institucionais de políticas públicas. Brasília: IPEA, 2014. 
GRAEFF, Fernando. Uma análise da alocação de riscos nos contratos para prestação de serviços públicos: o caso do transporte rodoviário interestadual de passageiros por ônibus. Monografia de conclusão de curso de especialização em Controle da Regulação. Brasília: TCU, 2011.

GRAU, Eros Roberto. A ordem econômica na Constituição de 1988 : interpretação e crítica. $13^{\mathrm{a}}$.ed. São Paulo : Malheiros, 2008.

IFC. Handshake: 7. October, 2012. Disponível em http://www.ifc.org/wps/wcm/connect/AS_ext_content/what+we+do/advisory+ services/about+us/public-

private+partnerships/publications/handshake/handshake, acesso em 10/06/2013.

IPEA. Comunicados do IPEA n. 94: Série Eixos do Desenvolvimento Brasileiro. "Infraestrutura Social e Urbana no Brasil subsídios para uma agenda de pesquisa e formulação de políticas públicas - A mobilidade urbana no Brasil". 2011, Brasil. Disponível em www.ipea.gov.br, acesso em 11/03/2012. (IPEA, 2011a)

IPEA. SIPS: Sistema de Indicadores de Percepção Social - mobilidade urbana, 4 de maio de 2011. Disponível em www.ipea.gov.br, acesso em 11/03/2012. (IPEA, 2011b).

ITP. Privatisation and Regulation of Urban transit Systems. ITF Roundtables n. 141, 2008. Disponível em http://www.internationaltransportforum.org/Pub/pdf/08rt141.pdf , acesso em 10 de outubro de 2012.

LENDER, J.; MANDRI-PERROT, C. Mass Rapit Transit - A tool for urban expansion. In Handshake, 7, p. 62-65, 2012. Disponível em http:/www1.ifc.org/wps/wcm/connect/3ae1f3804d0b378eb472f5f81ee631cc/ Handshake_Issue7_online.pdf?MOD=AJPERES, acesso em 10 de janeiro de 2013.

LE GALÈS, Patrick; SCOTT, Alan. A British Bureaucratic Revolution? Autonomy without control or "free market, more rules". Revue Française de sociologie. 2010

LE GALES, Patrick; LASCOUMES, Pierre. A ação pública abordada por seus instrumentos. Revista de Pós-Graduação em Ciências Sociais. V. 9, n. 18, Julho a Dezembro, 2012. Disponível em http://www.periodicoseletronicos.ufma.br/index.php/rpcsoc/article/viewFile/1 $331 / 1048$

LOPES, José Reinaldo. Transcrição da participação na mesa de debates 1 "Inovação dos Métodos de Pesquisa em Direito e Renovação da Produção Científica", realizada no $1^{\circ}$ Encontro de Pesquisa Empírica em Direito. 2011. Disponível em http://reedpesquisa.org/publicacoes/i-eped/, acesso em 03/10/2014. 
MARQUES NETO, Floriano de Azevedo. A Nova Regulamentação dos Serviços Publicos. Revista Eletrônica de Direito Administrativo Econômico, Salvador, Instituto de Direito Público da Bahia, no. 1, fevereiro, 2005. Disponível na Internet: <http://www.direitodoestado.com.br $>$. Acesso em 19/06/2012.

. Limites à Abrangência e à Intensidade da Regulação Estatal. Revista Eletrônica de Direito Administrativo Econômico, Salvador, Instituto de Direito Público da Bahia, no. 4, nov/dez 2005, jan 2006. Disponível na Internet: <http://www.direitodoestado.com.br>. Acesso em 19/06/2012.

- Fundamentos e conceituação das PPP. In MARQUES NETO, Floriano de Azevedo; SCHIRATO, Vitor Rhein (orgs.). Estudos sobre a lei das parcerias público-privadas. Belo Horizonte: Forum, 2011.

MARQUES NETO, Floriano de Azevedo; SCHIRATO, Vitor Rhein (orgs.). Estudos sobre a lei das parcerias público-privadas. Belo Horizonte: Forum, 2011.

MATTOS, Paulo T. L. Regulação econômica e democracia: contexto e perspectivas na compreensão das agências de regulação no Brasil. In FARIA, José E. (org.) Regulação, Direito e Democracia. São Paulo: Perseu Ábramo, 2002.

METRO. Pesquisa origem-destino 2007. Disponível em http://www.metro.sp.gov.br/metro/numeros-pesquisa/pesquisa-origemdestino-2007.aspx , acesso em 10 de novembro de 2012.

MEYER, Antônio C.; ENEI, José V.L.; Artigos sobre Parcerias público-privadas. $2004 . \quad$ Disponível em http://www.bnb.gov.br/content/aplicacao/desenvolvimento_em_acao/projeto_ ppp/docs/artigos_consultoria_machado_meyer_sobre_ppp.pdf , acesso em 10/06/2013.

MONTEIRO, Vera C. C. A caracterização do contrato de concessão após a edição da lei 11.079/2004. Tese de Doutorado apresentada na Faculdade de Direito da Universidade de São Paulo. 2009.

NOBRE, Eduardo A. C. Desenvolvimento Urbano e Sustentabilidade: Uma reflexão sobre a Grande São Paulo no começo do século XXI. NUTAU, 2004. Disponível em http://www.fau.usp.br/docentes/depprojeto/e nobre/desenvolvimento urbano sustentabilidade.pdf , acesso em 10 de junho de 2013.

NORTH, Douglass. Institutions, institutional change and economic performance. Cambridge, Cambridge University Press, 1994.

OECD. Tansport Infrastructure Investment: Options for efficiency. 2008. Disponível em www.oecd.org

PARGENDLER, Mariana; SALAMA, Bruno. Direito e Consequência no Brasil: em busca de um discurso sobre o método. In Revista de Direito 
Administrativo - RDA, Rio de Janeiro, v. 262, p. 95-144, 2013.

PEREIRA, Bruno R. Procedimento de Manifestação de Interesse nos Estados. 2012 Disponível, mediante cadastro, no site www.pppbrasil.com.br .

PIRES, Álvaro. Sobre algumas questões epistemológicas de uma metodologia geral para as ciências sociais. In POUPART, Jean et al(org.) A pesquisa qualitativa: enfoques epistemológicos e metodológicos. $2^{\mathrm{a}}$ edição, Vozes: Petrópolis, 2010. p. 43-94. (2010 a)

. Amostragem e pesquisa qualitativa: ensaio teórico e metodológico. In POUPART, Jean et al(org.) A pesquisa qualitativa: enfoques epistemológicos e metodológicos. $2^{\mathrm{a}}$ edição, Vozes: Petrópolis, 2010. p. 154211. (2010b)

PINTO JÚNIOR, Mário Engler. Empresa estatal: função econômica e dilemas societários. 2a ed. São Paulo: Atlas, 2013.

PPPBRASIL. $\mathbf{1}^{\mathbf{0}}$ Banco de Dados das PPPs. 2011. Disponível em www.pppbrasil.org

PRADO, Mariana M. What is Law and Development? In Revista Argentina de Teoria Juridica, Vol. 11, n. 1, 2010.

RACO, Mike. Delivering Flagship Projects in an Era of Regulatory Capitalism: Stateled Privatization and the London Olympics 2012. International Journal of Urban and Regional Research, 38(1), 176-197. 2013.

RAMIA, G. The 'new contractualism', social protection and the Yeatman thesis. Journal of Sociology 38.1, 49-68. 2002.

RIBEIRO, Mauricio P. Concessões e PPPs: melhores práticas em licitações e contratos. São Paulo: Atlas, 2011.

RIBEIRO, Mauricio P.; PRADO, Lucas N. Comentários à lei de PPP. São Paulo: Malheiros, 2010.

RODRIK, Dani; SUBRAMANIAN, Arvind; TREBBI, Francesco. Institutions Rule: The Primacy of Institutions over Geography and Integration in Economic Development. National Bureau of Economic Research Working Paper Series, working paper 9305; 2002. Disponível em www.nber.org/papers/w9305

ROSENAU, Pauline V (org.). Public-Private Policy Partnerships. The MIT Press: Cambridge, 2000.

SABEL, Charles. Bootstrapping Development: rethinking the role of public intervention in promoting growth, Paper presented at the Protestant Ethic and Spirit of Capitalism Conference, Cornell University, October, 2004, p. 2-21.

SABEL, Charles; REDDY, Sanjay. Learning to Learn: Undoing the gordian knot of development today. In Challenge 50:5 (2007), 73-92. Disponível em http://www.sanjayreddy.net/storage/papers/journal- 
articles/5Learning to learnChallenge.pdf, acesso em 10/06/2013.

SANTOS, A. The World Bank's Uses of the "Rule of Law" Promise in Economic Development. In: TRUBEK, D.; SANTOS, A. (eds.) The New Law and Economic Development: A Critical Appraisal. Nova York: Cambridge University, 2006, p. 253-300.

SAMPAIO, B. ; LIMA NETO, Oswaldo ; SAMPAIO, Yony . Eficiencia e Gestao no Planejamento do Transporte Publico Metropolitano. Planejamento e Políticas Públicas (IPEA), v. 29, p. 101-121, 2006.

SCHAPIRO, Mario. Novos parâmetros para a intervenção do Estado na Economia. Tese de Doutrado defendida na Faculdade de Direito da Universidade de São Paulo. 2009.

SIFFERT FILHO, Nelson. A expansão da infraestrutura no Brasil e o Project Finance. in ALEM, Ana Cláudia; GIAMBIAGI, Fabio."O BNDES em um brasil em transição". p. 211-224, 2010.

SILVA, Claudio O. Uso racional do automóvel. Revista Desafios do Desenvolvimento, janeiro/fevereiro, 2010. p. 33.

SILVA FILHO, Osny; OLIVEIRA, Rafael B. Kick-off: contract law as institutional architecture. 2013, inédito.

STIGLER, G. Theory of Economic Regulation. The Bell Journal of Economics and Management Science. Vol. 2. Num 1. P.3-21. 1971. Disponível em http://www.jstor.org/stable/3003160, acesso em 05/10/2010,

SUNDFELD, Carlos Ari. Direito Administrativo para céticos. São Paulo: Malheiros, 2013.

SUNDFELD, Carlos Ari (coord.). Parcerias públicos privadas. $2^{\mathrm{a}}$ edição. São Paulo: Malheiros, 2011a.

SUNDFELD, Carlos Ari. Guia Jurídico das parcerias público-privadas. (2011b) In SUNDFELD, Carlos Ari (coord.). Parcerias públicos privadas. $2^{\mathrm{a}}$ edição. São Paulo: Malheiros, 2011.

TORRES, Rodolfo; AROEIRA, Cleverson. O BNDES e a estruturação de projetos de infraestrutura. in ALEM, Ana Cláudia; GIAMBIAGI, Fabio. "O BNDES em um brasil em transição". 2010.

TRUBEK, David. Developmental States and the Legal Order: Towards a New Political Economy of Development and Law, 2010, disponível em: http://www.law.wisc.edu/gls/lands.html

TRUBEK, David; COUTINHO, Diogo R.; SCHAPIRO, Mario G. New State Activism in Brazil and the challenge for legal isntitutions. Legal Studies Research Paper Series, University of Wisconsin, paper n. 1207. Disponível em http://ssrn.com/abstract=2144939 . 
UBBELS, B; NIJKAMP, P. Unconventional funding of urban public transport. In Transport Research Part D, 7, p. 317-329, 2002.

UNGER, Roberto Mangabeira; LOTHIAN, Tamara. "Crisis, Slump, Superstition and Recovery Thinking and acting beyond vulgar Keynesianism”, 2011, disponível em: http://www.law.harvard.edu/faculty/unger/english/pdfs/JOINT_PIECE.pdf

VALENTE, Patrícia R. P. Um relação entre Economia e Direito: lições da Economia Institucional sobre as obras dos metrôs paulista e baiano. Revista de Direito Público da Economia, v. 38, p. 177-193, 2012.

VALOR. Infraestrutura. Revista Valor Econômico Setorial, Junho de 2013. Disponível em http://www.revistavalor.com.br/home.aspx?pub=6\&edicao=5 , acesso em 10/06/2013.

VASCONCELLOS, Eduardo A. Transportes urbanos em países em desenvolvimento: reflexões e propostas. $3^{\text {a }}$ ed. São Paulo: Annablume, 2000.

VASCONCELlOS, Eduardo A.; CARVALHO, Carlos H.; PEREIRA, Rafael H. Transporte e mobilidade urbana. Textos para discussão CEPAL-IPEA n. 34. CEPAL- Escritório Brasil/IPEA, 2011. Disponível em http://www.eclac.org/publicaciones/xml/8/43438/CEPAL 34.pdf, acesso em 22 de outubro de 2012.

WILLOUGHBY, Christopher. How much can public-private partnerships really do for urban transportation in developing countries? In Research in Transportation Economics 40 (2013), 34-55. Disponível em http://linkinghub.elsevier.com/retrieve/pii/S0739885912001102, acesso em 10/06/2013.

YIN, Robert. Estudo de caso: planejamento e método. Porto Alegre: Bookman, 2010. 


\section{Anexo 1 - Roteiro de Entrevistas}

- Por quais motivos você acredita que foi escolhido esse modelo (PPP)?

- A operação da linha 4 do metrô foi licitada por edital conduzido pela Cia do Metropolitano. Isso influenciou de alguma maneira o conteúdo do contrato? Quais consequências podem ser atribuídas a esse fato?

- Como ocorreram as interações entre público e privado nas negociações e sugestões de alteração? Qual era o nível de abertura das partes para a troca de informações e diálogo?

- Surgiram problemas na determinação das formas de pagamento? Como isso foi solucionado?

- Quais foram os principais instrumentos de garantia de ambos os lados? Se restringiram ao que foi chamado de garantia no contrato (i.e. penhor e seguro fiança)?

- Qual a relação entre os instrumentos de garantia e a forma de financiamento do projeto?

- O contrato da linha 6 do metrô é a primeira PPP do Estado de obras e serviços em transporte público urbano, isso gerou algum tipo de dificuldade na sua redação/negociação? Quais?

- Como os estudos apresentados no PMI foram selecionados e fracionados para formar o projeto que foi licitado? Houve alguma forma de diálogo informal do Estado de São Paulo com os interessados para determinar quais partes de quais estudos seriam utilizadas? Como isso funcionou e foi orquestrado?

- Quais mecanismos de sucesso do contrato da linha 4 foram mantidos?

- O que mudou mas deveria ter sido mantido?

- O que mudou em virtude de problemas constatados na linha 4?

- Quais as principais modificações que foram adotadas em virtude de problemas constatados na execução do contrato da linha 4? Como a percepção desses problemas levou a essas modificações? 


\section{Anexo 2 - Lista de Entrevistados}

Entrevistado 1 - Procurador do Estado envolvido nos processos de elaboração dos editais das linhas 4 e 6 .

Entrevistado 2 - Alto-executivo (diferentes cargos) do MetroSP de 2002 a 2012.

Entrevistado 3 - Servidor da Fazenda Estadual desde a década de 1990 e Executivo da CPP desde 2004.

Entrevistado 4 - Consultor independente do MetroSP na elaboração da linha 4, advogado e professor em direito administrativo e regulação.

Entrevistado 5 - Executivo responsável pela área de Concessões do grupo CCR.

Entrevistado 6 - Gestor do Contrato da Concessão da Viaquatro.

Entrevistado 7 - Analista financeiro da Viaquatro.

Entrevistado 8 - Consultor jurídico de empresa parte integrante do consórcio vencedor da concorrência da linha 6 e parecerista em processo judicial envolvendo a linha 4. Advogado e professor em direito administrativo e regulação. 


\section{Anexo 3 - Termo de Consentimento}

\section{Formulário de Consentimento para Entrevista}

O senhor foi convidado para contribuir com a pesquisa de Mestrado realizada por Pedro do Carmo Baumgratz de Paula (doravante "pesquisador") sobre o tema "As parcerias público-privadas do metrô de São Paulo", a ser apresentada perante o Departamento de Direito Econômico, Financeiro, Tributário e Ambiental da Faculdade de Direito da Universidade de São Paulo, sob a orientação do Prof. Associado Diogo Rosenthal Coutinho.

Caso o senhor/a concorde em contribuir com essa pesquisa, será convidado a conceder uma entrevista sobre o tema e sobre sua experiência a respeito do tema.

Mediante sua autorização, a entrevista será gravada e posteriormente transcrita e seu teor será utilizado para fins exclusivamente acadêmicos. Uma cópia da transcrição ser-lhe-á enviada e, caso o(a) Senhor(a) queira, poderá fazer correções, comentários suplementares ou supressões de informações.

Caso o senhor não concorde em ter seu nome citado no trabalho, a confidencialidade de todos os arquivos relacionados à pesquisa será rigorosamente mantida por intermédio da atribuição de pseudônimo a todas as falas transcritas, de forma que os dados não possam ser relacionados à sua identidade em nenhuma hipótese.

Uma cópia preenchida e assinada deste formulário de consentimento ficará em seu poder.

$\mathrm{Eu}$, participar da pesquisa supramencionada.

(doravante "participante"), estou de acordo em

\section{Confidencialidade}

Sim, dou ao pesquisador autorização para usar meu nome ao citar o material proveniente da entrevista.

Não, prefiro que meu nome não seja mencionado e que o pesquisador utilize um pseudônimo.

\section{Autorização para trabalhos relacionados}

Sim, dou ao pesquisador autorização para utilizar as informações provenientes dessa entrevista em outros trabalhos acadêmicos relacionados ao tema, para além de sua dissertação de mestrado, mantidas as condições aceitas nesse termo.

Não, prefiro que a entrevista seja utilizada somente para fins da dissertação.

Assinatura do participante

Assinatura do pesquisador

\section{Data}




\section{Anexo 4 - Lista de Documentos}

Os principais documentos envolvidos no caso, que constam da pasta abaixo, são:

\section{Linha 4:}

Contract BM n. 4646-BR - contrato de financiamento da obra da linha 4

Contrato de Penhor de quotas da CPP em favor da Concessionária

Edital de Concorrência Internacional n. 42325212/2005 - Edital de Concessão Patrocinada da Linha 4

Contrato n. 4232521201/2006 - Contrato da Concessão Patrocinada

\section{Linha 6:}

Chamamento Público 001/2011 - Documento que instaurou o PMI que deu origem à Linha 6

Edital de Concorrência Internacional 004/2013 - Edital da Concessão Patrocinada da Linha 6

Contrato de Concessão Patrocinada 015/2013 - Contrato da Concessão Patrocinada da Linha 6

\section{MetroSP:}

Balanço Financeiro relativo ao ano fiscal de 2013.

\section{SPTrans:}

Regulamento da Câmara de Arrecadação e Pagamento Conjunta do Sistema de Transportes

A totalidade dos documentos citados encontra-se, de forma mais acessível ou não, disponível ao público.

No entanto, para facilitar o acesso do leitor aos documentos oficiais, todos os contratos, editais, relatórios e outros documentos citados nesse anexo estarão disponíveis na seguinte pasta criada pelo autor: https://www.dropbox.com/sh/paa69sjy7sraziw/AADIPGuNrm14c5B7ru86IXE$\underline{\mathrm{a} ? \mathrm{dl}=0}$ 


\section{Anexo 5 - Cláusulas citadas do contrato da Linha 4}

\section{CLÁUSULA SEXTA - REMUNERAÇÃO E PAGAMENTOS}

6.1 A remuneração da CONCESSIONÁRIA será composta pelas seguintes parcelas:

Parcela A: RECEITA TARIFÁRIA obtida por meio de tarifa de remuneração fixada em $\mathrm{R} \$ 2,08$ (dois reais e oito centavos) por passageiro transportado, na data base de 10 de fevereiro de 2005 (TARIFA DE REMUNERAÇÃO), observada a Cláusula Oitava.

Parcela B: Contraprestação pecuniária devida pelo PODER CONCEDENTE (CONTRAPRESTAÇÃO PECUNIÁRIA), a ser paga, em duas etapas, da seguinte forma:

24 (vinte e quatro) parcelas mensais iguais e sucessivas, no valor de $\mathrm{R} \$ 1.562 .500,00$ (um milhão, quinhentos e sessenta e dois mil e quinhentos reais), na data base 01/08/2006, vencendo-se a primeira delas no dia 15 (quinze) do mês subseqüente ao mês de início da operação comercial da FASE I;

24 (vinte e quatro) parcelas mensais iguais e sucessivas, no valor de $\mathrm{R} \$ 1.562 .500,00$ (um milhão, quinhentos e sessenta e dois mil e quinhentos reais), na data base 01/08/2006, vencendo-se a primeira delas no dia 15 (quinze) do mês subseqüente à apresentação do conjunto de instrumentos jurídicos que comprovem a efetiva contratação do financiamento e fornecimento dos Trens Metroviários do Sistema de Material Rodante da FASE II.

\section{(...)}

\section{CLÁUSULA SÉTIMA - REAJUSTE}

7.1 A TARIFA DE REMUNERAÇÃO será reajustada anualmente, tendo como referência a data base de 1 o de fevereiro de 2005, de acordo com o disposto abaixo:

7.1.1 Durante os primeiros 15 (quinze) anos, a contar da data do início da operação comercial, pela seguinte fórmula paramétrica:

$\operatorname{Tr}=\operatorname{To} x[\mathrm{a}($ IGP-M / IGP-Mo $)+\mathrm{b}($ IPC / IPCo $)]$

Sendo:

$\operatorname{Tr}=$ TARIFA DE REMUNERAÇÃO da CONCESSIONÁRIA reajustada;

To = TARIFA DE REMUNERAÇÃO da CONCESSIONÁRIA na data base de 01/02/2005; IGP-M = Índice Geral de Preços de Mercado publicado pela Fundação Getúlio Vargas FGV no mês anterior ao da aplicação do reajuste; IGP-Mo = Índice Geral de Preços de Mercado publicado pela Fundação Getúlio Vargas - FGV no mês anterior à 01/02/2005; IPC = Índice de Preços ao Consumidor da Fundação Instituto de Pesquisas Econômicas FIPE/USP no mês anterior ao da aplicação do reajuste;

IPCo = Índice de Preços ao Consumidor da Fundação Instituto de Pesquisas Econômicas FIPE/USP no mês anterior à 01/02/2005.

Peso Desde a assinatura do CONTRATO, até 15 anos da operação

a $\quad 0,5$

b $\quad 0,5$

7.1.2 No primeiro reajuste da tarifa de remuneração após decorridos 15 (quinze) anos a contar da data do início da operação comercial, e para todos os reajustes subseqüentes, o reajuste se aplicará tomando-se como referência a tarifa vigente, pela seguinte fórmula 
paramétrica:

$\operatorname{Tr}=\operatorname{Tr}-1 \times[$ IPC / IPC -1$]$

Sendo:

Tr - TARIFA DE REMUNERAÇÃO da CONCESSIONÁRIA reajustada;

Tr-1 = TARIFA DE REMUNERAÇÃO da CONCESSIONÁRIA vigente no período anterior;

IPC = Índice de Preços ao Consumidor da Fundação Instituto de Pesquisas Econômica FIPE/USP no mês anterior ao da aplicação do reajuste;

IPC - 1 = Índice de Preços ao Consumidor da Fundação Instituto de Pesquisas Econômica FIPE/USP no mês anterior à última aplicação do reajuste previsto em 7.1.1. desta Cláusula.

$(\ldots)$

\section{CLÁUSULA OITAVA - RECEITAS}

8.1 O cálculo da RECEITA TARIFÁRIA levará em conta o seguinte critério:

a) $100 \%$ (cem por cento) da TARIFA DE REMUNERAÇÃO multiplicada pelo número de entradas de passageiros exclusivos, assim considerado aqueles, pagantes ou gratuitos, que utilizam exclusivamente a LINHA 4 - AMARELA, sem se utilizar de nenhuma outra linha metro- ferroviária (PASSAGEIRO EXCLUSIVO).

b) $50 \%$ (cinqüenta por cento) da TARIFA DE REMUNERAÇÃO multiplicada pelo número de entradas de passageiros integrados no sistema metro-ferroviário, assim considerado aqueles, pagantes ou gratuitos, que utilizam a LINHA 4 - AMARELA, em combinação com outras linhas operadas pela COMPANHIA DO METRÔ, da CPTM, ou de ambas, em qualquer sentido (PASSAGEIRO INTEGRADO).

8.2 A RECEITA TARIFÁRIA ficará sujeita ainda a ajustes em função do cumprimento pela CONCESSIONÁRIA dos indicadores de qualidade dos serviços prestados e de manutenção, descritos na Cláusula Décima Nona, seguindo a fórmula:

$\mathrm{RT}=[($ Pe $\mathrm{x}$ Tr $)+($ Pi x 0,5 Tr $)] \times[0,8+(0,10 \times$ Iqs $)+(0,10 \times$ Iqm $)]$

Sendo:

RT $=$ RECEITA TARIFÁRIA da CONCESSIONÁRIA;

$\mathrm{Pe}=$ Entradas de PASSAGEIROS EXCLUSIVOS;

$\mathrm{Pi}=$ Entradas de PASSAGEIROS INTEGRADOS;

$\operatorname{Tr}=$ TARIFA DE REMUNERAÇÃO;

Iqs $=$ Indicador de qualidade de serviço prestado. Será um número entre 0 e 1 ;

Iqm $=$ Indicador de qualidade de manutenção. Será um número entre 0 e 1.

8.3 A aplicação dos indicadores mencionados será efetuada a partir do 7o mês do início da operação comercial da FASE I.

8.4 A RECEITA TARIFÁRIA será recebida pela CONCESSIONÁRIA de acordo com as condições estabelecidas na Cláusula Nona.

\section{CLÁUSULA NONA - CENTRALIZAÇÃO DA ARRECADAÇÃo}

9.1 Como condição de emissão da ORDEM DE SERVIÇO DO PROJETO DA FASE I, deverá estar em operação sistema de arrecadação centralizada, que funcionará como uma câmara de compensação financeira do sistema metro-ferroviário do Estado de São Paulo e da empresa municipal São Paulo Transporte S.A. - SPTrans (SISTEMA DE ARRECADAÇÃO CENTRALIZADA), e ficará responsável: (i) pela arrecadação integral, 
controle, aferição e gerenciamento de todos os valores recebidos pela venda do direito de viagem no sistema metro-ferroviário, seja através do Bilhete Único da SPTrans ou outro que vier a substituí-lo, ou através de bilhetes Edmonson da COMPANHIA DO METRÔ e da CPTM; (ii) pelo controle da contagem física dos passageiros transportados que assegure a correta distribuição das receitas na forma do item 9.3 das Diretrizes Técnicas para a Concessão da Linha 4 - Amarela; (iii) pela distribuição dos valores assim arrecadados aos integrantes do sistema metro-ferroviário, incluindo-se a CONCESSIONÁRIA e a SPTrans; (iv) pelos pagamentos devidos à CONCESSIONÁRIA a título de RECEITA TARIFÁRIA, sempre com a estrita observância das disposições do CONTRATO e com os ajustes previstos nas Cláusulas Oitava (Receitas), Décima Primeira (Mitigação de Riscos) e Décima Nona (Avaliação); e (v) pela elaboração e remessa periódica à SPTrans, COMPANHIA DO METRÔ, CPTM e CONCESSIONÁRIA de relatórios detalhados em que conste a descrição de todos os eventos relativos à arrecadação e distribuição das receitas.

9.1.1 O SISTEMA DE ARRECADAÇÃO CENTRALIZADA será composto uma entidade com personalidade jurídica própria (CÂMARA DE COMPENSAÇÃO), não sujeita ao controle acionário direto ou indireto do Estado de São Paulo e dos Municípios integrantes do sistema de transporte de passageiros da Região Metropolitana de São Paulo. O detalhamento do sistema de centralização de arrecadação consta do Anexo IV do CONTRATO.

9.2 A partir da assinatura do CONTRATO, a CONCESSIONÁRIA passará a integrar o Comitê Gestor de Integração, constituído por representantes da COMPANHIA DO METRÔ, CPTM, SPTrans, Secretaria de Estado dos Transportes Metropolitanos (STM) e Secretaria Municipal de Transportes (SMT) (COMITÊ GESTOR DE INTEGRAÇÃO). O COMITÊ GESTOR DE INTEGRAÇÃO fiscalizará a operação do SISTEMA DE ARRECADAÇÃO CENTRALIZADA, em todas as suas etapas e estará obrigado a observar fielmente às disposições do CONTRATO relativas aos critérios de repartição da arrecadação tarifária aplicáveis à CONCESSIONÁRIA. A EMTU também poderá vir a integrar o SISTEMA DE ARRECADAÇÃO CENTRALIZADO, quando então ficará sujeita a todos os seus termos e condições.

9.2.1 No âmbito do COMITÊ GESTOR DE INTEGRAÇÃO, a CONCESSIONÁRIA terá as mesmas prerrogativas e obrigações dos demais integrantes (COMPANHIA DO METRÔ, CPTM e SPTrans), devendo: (i) participar de todas as decisões relativas ao sistema, com poder de veto em relação aos assuntos que afetem diretamente os seus legítimos interesses; (ii) participar conjuntamente com a COMPANHIA DO METRÔ, a CPTM e a SPTrans das atividades de fiscalização da arrecadação tarifária; (iii) participar conjuntamente com a COMPANHIA DO METRÔ, a CPTM e a SPTrans do estabelecimento das regras de operacionalização da repartição da arrecadação tarifária; e (iv) receber diariamente em sua conta bancária a parte que lhe cabe nas receitas comuns provenientes da arrecadação tarifária, a partir do início da operação comercial da FASE I da LINHA 4 - AMARELA.

9.3 A CÂMARA DE COMPENSAÇÃO será fiel depositária de todos os valores arrecadados, devendo para tanto contratar instituição financeira de primeira linha, não sujeita ao controle acionário direto ou indireto do Estado de São Paulo e dos Municípios integrantes do sistema de transporte de passageiros da Região Metropolitana de São Paulo. A CÂMARA DE COMPENSAÇÃO atuará por conta e ordem dos participantes do SISTEMA DE ARRECADAÇÃO CENTRALIZADA, cabendo-lhe distribuir diariamente os valores arrecadados, através da referida instituição financeira, conforme as regras de rateio definidas pelo COMITÊ GESTOR DE INTEGRAÇÃO, que ficará vinculado à observância das disposições previstas no CONTRATO. 
9.3.1 A CÂMARA DE COMPENSAÇÃO não poderá, em nenhuma hipótese, ceder, transferir, onerar, dispor ou de qualquer outra forma vincular o produto da arrecadação dos valores recebidos pela venda do direito de viagem do sistema metro-ferroviário.

9.3.2 A CONCESSIONÁRIA e os outros operadores integrantes do SISTEMA DE ARRECADAÇÃO CENTRALIZDA poderão ceder, onerar ou vincular apenas e tão somente a sua própria quota parte nas receitas comuns arrecadadas de forma centralizada, devendo comunicar o fato à CÂMARA DE COMPENSAÇÃO. Por sua vez, a CÂMARA DE COMPENSAÇÃO somente ficará obrigada a observar os termos do gravame, se o respectivo credor manifestar expressa e irrevogável concordância com as regras de funcionamento da CÂMARA DE COMPENSAÇÃO.

9.4 A COMPANHIA DO METRÔ, a CPTM, a SPTrans e a CONCESSIONÁRIA outorgarão poderes à CÂMARA DE COMPENSAÇÃO para proceder a arrecadação dos valores recebidos pela venda do direito de viagem do sistema de transporte de passageiros operado por cada um deles, bem como para distribuir o produto assim arrecadado, observando fielmente os critérios de cálculo e ajustes previstos no CONTRATO, relativamente à quota parte devida à CONCESSIONÁRIA.

9.5 A CÂMARA DE COMPENSAÇÃO não poderá alterar, terminar, rescindir ou dar causa à rescisão de qualquer contrato celebrado com a instituição financeira, sem o prévio e expresso consentimento do COMITÊ GESTOR DE INTEGRAÇÃO.

9.6 As receitas comuns arrecadadas pela CÂMARA DE COMPENSAÇÃO, enquanto não for efetuado o rateio entre a COMPANHIA DO METRÔ, a CPTM, a SPTrans e a CONCESSIONÁRIA, consideram-se em situação de condomínio voluntário, regido pelos artigos 1314 e seguintes do Código Civil.

9.7 A quota parte da COMPANHIA DO METRÔ e da CPTM nas receitas comuns terá caráter variável em função das regras de rateio previamente estabelecidas perante a CÂMARA DE COMPENSAÇÃO, com a observância dos critérios de cálculo e ajustes previstos no CONTRATO, e deverá ajustar-se ao valor do saldo apurado após a dedução da quota parte da CONCESSIONÁRIA.

9.8 A partir do início da operação da FASE I, a CONCESSIONÁRIA participará do rateio dos custos de funcionamento e manutenção do SISTEMA DE ARRECADAÇÃO CENTRALIZADA, incluindo a CÂMARA DE COMPENSAÇÃO, na proporção das receitas recebidas por cada operadora integrante do SISTEMA DE ARRECADAÇÃO CENTRALIZADA.

9.9 Caberá a recomposição do equilíbrio econômico-financeiro do CONTRATO, caso os custos de funcionamento e manutenção do SISTEMA DE ARRECADAÇÃO CENTRALIZADA, imputáveis à CONCESSIONÁRIA nos termos do item 9.8, superem a 6\% (seis por cento) da RECEITA TARIFÁRIA, sem considerar os ajustes previstos no item 8.2 .

9.9.1 Para efeito de aplicação do limite máximo de $6 \%$ previsto no item 9.9., será considerada a totalidade das RECEITAS TARIFÁRIAS relativas a cada ano civil.

$(\ldots)$

\section{CLAÚSULA DÉCIMA-PRIMEIRA - MITIGAÇÃO DE RISCOS}

(..)

11.1 Risco de não realização da demanda projetada:

(...) 
11.1.4 Caso a demanda trimestral real contabilizada esteja entre $90 \%$ (noventa por cento) e $110 \%$ (cento e dez por cento), inclusive, da DEMANDA PROJETADA para o período, não haverá nenhum ajuste nas receitas decorrentes da TARIFA DE REMUNERAÇÃO.

11.1.5 Caso a demanda trimestral real contabilizada esteja entre $90 \%$ (noventa por cento) e $80 \%$ (oitenta por cento), inclusive, da DEMANDA PROJETADA para o período, as receitas decorrentes da TARIFA DE REMUNERAÇÃO serão ajustadas para mais, mediante aplicação da seguinte fórmula:

$\mathrm{Md}=[0,6 \times(0,9 \times \mathrm{Dp}-\mathrm{Dr})] \times\{[\mathrm{Pi} /(\mathrm{Pi}+\mathrm{Pe}) \times \operatorname{Tr} \times 0,5]+[\mathrm{Pe} /(\mathrm{Pi}+\mathrm{Pe}) \times \mathrm{Tr}]\}$

11.1.6 Caso a demanda trimestral real contabilizada esteja entre de $80 \%$ (oitenta por cento) e $60 \%$ (sessenta por cento), inclusive, da DEMANDA PROJETADA para o período, as receitas decorrentes da TARIFA DE REMUNERAÇÃO serão ajustadas para mais, mediante aplicação da seguinte fórmula:

$\mathrm{Md}=\{[0,06 \times \mathrm{Dp}]+[0,9 \times(0,8 \times \mathrm{Dp}-\mathrm{Dr})]\} \times\{[\mathrm{Pi} /(\mathrm{Pi}+\mathrm{Pe}) \times \operatorname{Tr} \times 0,5]+[\mathrm{Pe} /$ $(\mathrm{Pi}+\mathrm{Pe}) \mathrm{x} \mathrm{Tr}]\}$

11.1.7 Caso a demanda trimestral real contabilizada esteja entre $110 \%$ (cento e dez por cento) e $120 \%$ (cento e vinte por cento), inclusive, da DEMANDA PROJETADA para o período, as receitas decorrentes da TARIFA DE REMUNERAÇÃO serão ajustadas para menos, mediante aplicação da seguinte fórmula:

$\mathrm{Md}=[0,6 \mathrm{x}(\mathrm{Dr}-1,1 \mathrm{xDp})] \mathrm{x}\{[\mathrm{Pi} /(\mathrm{Pi}+\mathrm{Pe}) \mathrm{xTrx} 0,5]+[\mathrm{Pe} /(\mathrm{Pi}+\mathrm{Pe}) \mathrm{x} \mathrm{Tr}]\}$

11.1.8Caso a demanda trimestral real contabilizada esteja entre $120 \%$ (cento e vinte por cento) e $140 \%$ (cento e quarenta por cento), inclusive, da DEMANDA PROJETADA para o período, as receitas decorrentes da TARIFA DE REMUNERAÇÃO serão ajustadas para menos, mediante aplicação da seguinte fórmula:

$\mathrm{Md}=\{[0,06 \mathrm{xDp}]+[0,9 \mathrm{x}(\mathrm{Dr}-1,2 \mathrm{xDp})]\} \times\{[\mathrm{Pi} /(\mathrm{Pi}+\mathrm{Pe}) \times \operatorname{Tr} \times 0,5]+[\mathrm{Pe} /(\mathrm{Pi}+\mathrm{Pe}) \mathrm{x}$ $\operatorname{Tr}]\}$

Sendo, para as fórmulas definidas neste item e nos itens 11.1.5., 11.1.6., 11.1.7. desta Cláusula:

$\mathrm{Md}=$ Valor do pagamento ou recebimento da CONCESSIONÁRIA referente a mitigação de demanda;

Dp = DEMANDA PROJETADA no trimestre;

$\mathrm{Dr}=$ Demanda real no trimestre;

$\mathrm{Pi}=$ Entradas de PASSAGEIROS INTEGRADOS no trimestre;

$\operatorname{Tr}=$ TARIFA DE REMUNERAÇÃO;

$\mathrm{Pe}=$ Entradas de PASSAGEIROS EXCLUSIVOS no trimestre.

11.1.9 Caso a demanda trimestral real contabilizada esteja abaixo de 60\% (sessenta por cento) ou acima de $140 \%$ (cento e quarenta por cento) da DEMANDA PROJETADA para o período, caberá a recomposição do equilíbrio econômico-financeiro em favor da concessionária, no primeiro caso, e em favor do PODER CONCEDENTE, no segundo caso.

$(\ldots)$

11.13 A Companhia Paulista de Parcerias (CPP) assume neste ato, em caráter irrevogável e irretratável, a condição de fiador solidariamente responsável pelo fiel cumprimento das obrigações imputáveis ao PODER CONCEDENTE, no que se refere exclusivamente ao pagamento da COMPENSAÇÃO DE ATRASO DA FASE I, COMPENSAÇÃO DE ATRASO DA FASE II, COMPENSAÇÃO DE DEMORA NA EMISSÃO DA ORDEM DE SERVIÇO, PRIMEIRA MULTA COMPENSATÓRIA DE RESCISÃO, SEGUNDA MULTA COMPENSATÓRIA DE RESCISÃO e CONTRAPRESTAÇÃO PECUNIÁRIA, observados os limites e restrições previstas no CONTRATO(OBRIGAÇÕES 
SOLIDÁRIAS), renunciando expressamente aos benefícios previstos nos artigos 827, 834, 835, 837, 838 e 839 do Código Civil e no artigo 595 do Código de Processo Civil. A presente fiança terá vigência a partir da assinatura do CONTRATO e perdurará até o pagamento integral das OBRIGAÇÕES SOLIDÁRIAS.

11.14. Para garantia da fiança prestada em relação às OBRIGAÇÕES SOLIDÁRIAS, a CPP constitui neste ato o penhor sobre títulos da dívida pública federal e/ou sobre quotas de Fundo de Investimento lastreado em títulos da dívida pública federal, cujo valor total será de $\mathrm{R} \$ 210.000 .000,00$ (duzentos e dez milhões de reais), acrescido do mesmo reajuste aplicável à TARIFA DE REMUNERAÇÃO, na data do vencimento das OBRIGAÇÕES SOLIDÁRIAS (PENHOR).

11.14.1 O PENHOR reger-se-á pelo disposto no artigo 1.431 e seguintes do Código Civil e será melhor disciplinado em documento próprio firmado na mesma data do CONTRATO, devendo necessariamente conter as seguintes condições, além de outras consideradas usuais para esse espécie de garantia:

- os títulos da dívida pública federal deverão ter a forma escritural, cotação de mercado e registro em sistema centralizado de liquidação e custódia, autorizado a funcionar pelo Banco Central do Brasil;

- o Fundo de Investimento constituído para atender ao disposto no item 11.4 deverá ter a CPP como única quotista e aplicará os recursos alocados em títulos da dívida pública federal;

- após a constituição do Fundo de Investimento, o seu regulamento somente poderá ser alterado com a concordância da CONCESSIONÁRIA;

- o gravame do PENHOR estender-se-á automaticamente aos rendimentos produzidos pelos títulos da dívida pública federal ou quotas do Fundo de Investimento ;

- os títulos da dívida pública federal ou as quotas do Fundo de Investimento permanecerão indisponíveis e na custódia de instituição financeira independente, durante toda a vigência do PENHOR;

- a CPP outorgará poderes irrevogáveis à instituição financeira custodiante para liquidar os títulos da dívida pública federal ou das quotas do Fundo de Investimento, no valor necessário ao pagamento das OBRIGAÇÕES SOLIDÁRIAS inadimplidas;

- no caso de inadimplemento das OBRIGAÇÕES SOLIDÁRIAS pelo PODER CONCEDENTE, a CONCESSIONÁRIA deverá comunicar o fato a CPP, concedendo-lhe o prazo de 5 (cinco) dias corridos para o pagamento espontâneo;

- vencido o prazo de 5 (cinco) dias, sem que tenha ocorrido o pagamento espontâneo, a CONCESSIONÁRIA poderá solicitar diretamente à instituição financeira custodiante a imediata liquidação dos títulos da dívida pública federal ou quotas do Fundo de Investimento empenhados e o pagamento das OBRIGAÇÕES SOLIDÁRIAS inadimplidas;

- o PENHOR subsistirá até o início da operação comercial da FASE II, desde que tenham sido integralmente cumpridas as OBRIGAÇÕES SOLIDÁRIAS, não sendo admitida a extinção parcial da garantia, sem a concordância expressa da CONCESSIONÁRIA.

$(\ldots)$ 


\section{Anexo 6 - Cláusulas citadas do contrato da Linha 6}

\section{CLÁUSULA SEXTA _ DA REMUNERAÇÃO E PAGAMENTOS 6.1. A}

remuneração da CONCESSIONÁRIA será composta pelas seguintes parcelas:

6.1.1. PARCELA A _ Receita decorrente da TARIFA DE REMUNERAÇÃO, fixada em R\$ 1,60 (um real e sessenta centavos), por passageiro transportado, na data base de $01 / 02 / 2013$.

6.1.1.1. A CONCESSIONÁRIA receberá a PARCELA A a partir do início da OPERAÇÃO COMERCIAL ou da OPERAÇÃO COMERCIAL ANTECIPADA, plena ou parcial, de acordo com as condições estabelecidas na Cláusula Vigésima Oitava „ Da Centralização da Arrecadação e da Receita decorrente da Tarifa de Remuneração, deste CONTRATO.

6.1.2. PARCELA B: CONTRAPRESTAÇÃO PECUNIÁRIA devida pelo PODER CONCEDENTE, no valor anual de R\$ ......(identificar o valor proposto com o desconto) .....(extenso), na data base de / / (mês de apresentação da proposta), resultante da aplicação do desconto único em percentual de.............\% (extenso) ofertado pela CONCESSIONÁRIA, conforme Planilha de Preços Propostos da Contraprestação Pecuniária com Cronograma Físico- Financeiro, Anexo III, Volume II, deste CONTRATO.

6.1.2.1. A CONTRAPRESTAÇÃO PECUNIÁRIA será paga mensalmente pelo PODER CONCEDENTE à CONCESSIONÁRIA, após o início da OPERAÇÃO COMERCIAL, vinculada ao desempenho, mediante aplicação dos indicadores IQM e IQS, Indicador da Qualidade dos Serviços de Manutenção e Indicador de Qualidade do Serviço Prestado, respectivamente, previstos na Cláusula Décima Nona da Mensuração de Desempenho deste CONTRATO.

$(\ldots)$

\section{CLÁUSULA VIGÉSIMA _ DA REPARTIÇÃO DOS RISCOS E SUA MITIGAÇÃO}

(...)

\subsection{DO RISCO DE DEMANDA - COMPARTILHAMENTO}

20.7.1 O risco de não realização da demanda projetada pelo PODER CONCEDENTE será assumido pela CONCESSIONÁRIA e será mitigada mediante a utilização do mecanismo detalhado abaixo:

20.7.1.1 o mecanismo de mitigação do risco de demanda projetada será aplicado depois de transcorridos 12 (doze) meses do mês 73o (septuagésimo terceiro) de CONCESSÃO, estabelecido como início da OPERAÇÃO COMERCIAL, e perdurará por 10 (dez) anos.

20.7.1.2 no caso de OPERAÇÃO COMERCIAL ANTECIPADA parcial não será considerado o mecanismo de mitigação do risco de demanda;

20.7.1.3 decorridos os 12 (doze) meses de que trata o item 20.7.1.1, caso a demanda trimestral real contabilizada esteja entre $85 \%$ (oitenta e cinco por cento) e $115 \%$ (cento e quinze por cento), inclusive, da DEMANDA PROJETADA para o período, não haverá nenhum ajuste extraordinário à receita decorrente da TARIFA DE REMUNERAÇÃO;

20.7.1.4 caso a demanda trimestral real contabilizada esteja entre $85 \%$ (oitenta e cinco por cento) e $70 \%$ (setenta por cento), inclusive, da DEMANDA PROJETADA para o período, haverá ajuste extraordinário para mais na receita decorrentes da TARIFA DE REMUNERAÇÃO, mediante aplicação da seguinte fórmula: 
$\mathrm{Md}=\left[0,6 \times\left((0,85 \times \mathrm{Dp}) \_\mathrm{Dr}\right) \mathrm{x} \mathrm{Tr}\right]$, onde:

$\mathrm{Md}=$ Valor do pagamento ou recebimento da CONCESSIONÁRIA referente à mitigação de demanda; $\mathrm{Dp}=$ DEMANDA PROJETADA no trimestre; $\mathrm{Dr}=$ Demanda real no trimestre;

$\mathrm{Tr}=$ TARIFA DE REMUNERAÇÃO;

20.7.1.5 caso a demanda trimestral real contabilizada esteja entre $70 \%$ (setenta por cento) e $60 \%$ (sessenta por cento), inclusive, da DEMANDA PROJETADA para o período, haverá ajuste extraordinário para mais na receita decorrentes da TARIFA DE REMUNERAÇÃO, mediante aplicação da seguinte fórmula:

$\mathrm{Md}=\left\{[0,09 \times \mathrm{Dp}]+\left[0,9 \times\left((0,7 \times \mathrm{Dp})_{\longleftarrow} \mathrm{Dr}\right)\right]\right\} \times \mathrm{Tr}$

20.7.1.6 caso a demanda trimestral real contabilizada esteja entre $115 \%$ (cento e quinze por cento) e $130 \%$ (cento e trinta por cento), inclusive, da DEMANDA PROJETADA para o período, a receita decorrente da TARIFA DE REMUNERAÇÃO será ajustada para menos, mediante aplicação da seguinte fórmula:

$\mathrm{Md}=[0,6 \times(\mathrm{Dr} \leftarrow(1,15 \times \mathrm{Dp})) \times \mathrm{Tr}]$

20.7.1.7 caso a demanda trimestral real contabilizada esteja entre $130 \%$ (cento e trinta por cento) e $140 \%$ (cento e quarenta por cento), inclusive, da DEMANDA PROJETADA para o período, as receitas decorrentes da TARIFA DE REMUNERAÇÃO serão ajustadas para menos, mediante aplicação da seguinte fórmula:

$\mathrm{Md}=\left\{[0,09 \times \mathrm{Dp}]+\left[0,9 \times\left(\mathrm{Dr}_{\longleftarrow}(1,3 \times \mathrm{Dp})\right)\right]\right\} \times \mathrm{Tr}$

20.7.1.8 caso a demanda trimestral real contabilizada esteja abaixo de $60 \%$ (sessenta por cento) ou acima de $140 \%$ (centro e quarenta por cento) da DEMANDA PROJETADA para o período, caberá a recomposição do equilíbrio econômico- financeiro, com a observância de todos os procedimentos necessários à demonstração inequívoca de seu cabimento, seja em favor da CONCESSIONÁRIA, seja em favor do PODER CONCEDENTE;

20.7.1.9 o mecanismo de mitigação do risco de demanda leva em consideração o Anexo VIII _ Estudos de Demanda, a partir do qual se elaboraram as projeções trimestrais de demanda para a FASE II _ DEMANDA PROJETADA, que foram realizadas levando-se em conta a sazonalidade esperada e agrupadas de acordo com os trimestres civis (1o Trimestre _ JanMar) (2o Trimestre _ Abr.-Jun.) (3o Trimestre _ Jul-Set) (4o Trimestre „ Out-Dez).

(...)

\section{CLÁUSULA VIGÉSIMA SÉTIMA _ DO APORTE DE RECURSOS}

27.1 Nos termos da Lei Federal no 11.079/04 e suas alterações, a CONCESSÃO contempla APORTE DE RECURSOS por parte do PODER CONCEDENTE, no valor máximo de $\mathrm{R} \$$ 4.469.400.000,00 (quatro bilhões, quatrocentos e sessenta e nove milhões e quatrocentos mil reais), data base do mês de apresentação da proposta, cuja percepção pela CONCESSIONÁRIA se dará em conformidade com o Fluxo de Desembolso de Parcelas do Aporte de Recursos - Volume I, do Anexo VI, em parcelas, até o 6o ano da CONCESSÃO, em função da efetiva execução dos investimentos, envolvendo construção (obra civil) e aquisição de bens reversíveis, para a implantação da LINHA 6, observada a proporcionalidade com as etapas efetivamente executadas, as quais estão vinculadas aos Eventos estabelecidos na evolução da implantação da Linha e na aferição de sua efetiva realização.

(...)

27.8 O APORTE DE RECURSOS será assegurado pelo PODER CONCEDENTE por meio 
de financiamento obtido junto ao Banco Nacional de Desenvolvimento Econômico e Social ("BNDES") e, em caráter complementar, por recursos orçamentários, declarando o PODER CONCEDENTE, nesta oportunidade, que:

27.8.1 obteve autorização legislativa para contratação do financiamento junto ao BNDES;

27.8.2 formalizou junto ao BNDES pedido de enquadramento do projeto de implantação da LINHA 6 do Metrô;

27.8.3 acordou com o BNDES a adequação dos termos do financiamento às disposições do presente CONTRATO.

27.9 Os recursos obtidos pelo PODER CONCEDENTE junto ao BNDES para o financiamento do projeto objeto deste CONTRATO serão depositados pela referida instituição financeira em Conta Vinculada ao projeto, destinada, exclusivamente, à liberação à CONCESSIONÁRIA dos valores de APORTE DE RECURSOS a que a mesma venha a fazer jus em face do cumprimento das obrigações previstas no presente CONTRATO, na forma disciplinada no item 27.2.

(...)

\section{CLÁUSULA QUINQUAGÉSIMA SEGUNDA — DA GARANTIA DA CONTRAPRESTAÇÃO PECUNIÁRIA}

52.1 O Poder Concedente obriga-se a assegurar os recursos orçamentários necessários ao pagamento da CONTRAPRESTAÇÃO PECUNIÁRIA, conforme estabelecido na Cláusula Sexta, item 6.3 deste CONTRATO, incluindo na proposta orçamentária anual dotação específica, vinculada à Secretaria dos Transportes Metropolitanos, em valor suficiente para suportar o pagamento da CONTRAPRESTAÇÃO PECUNIÁRIA para o exercício subsequente, bem como vetar alterações na referida proposta que reduzam ou restrinjam a dotação destinada ao pagamento da CONTRAPRESTAÇÃO PECUNIÁRIA e não efetuar contingenciamento de tais recursos.

52.2 A Companhia Paulista de Parcerias _ CPP assume neste ato, em caráter irrevogável e irretratável, a condição de fiadora solidariamente responsável pelo fiel cumprimento da obrigação imputável ao PODER CONCEDENTE, no que se refere, exclusivamente, ao pagamento do valor correspondente a 6 (seis) prestações mensais da CONTRAPRESTAÇÃO PECUNIÁRIA (Obrigação Solidária), que vigorará, de acordo com os limites e condições estabelecidos nesta Cláusula, a partir do início da OPERAÇÃO COMERCIAL ou da OPERAÇÃO COMERCIAL ANTECIPADA, plena ou parcial, até a liquidação final, pelo PODER CONCEDENTE, da última parcela da CONTRAPRESTAÇÃO PECUNIÁRIA, renunciando expressamente ao benefício previsto no artigo 827 do Código Civil.

52.3 A Obrigação Solidária será assegurada mediante penhor, instituído nos termos do artigo 1.431 do Código Civil Brasileiro (Garantia Real), no prazo máximo de 30 (trinta) dias contados da assinatura do CONTRATO, sobre cotas do Fundo de Investimento em Cotas de Fundos de Investimento Renda Fixa Longo Prazo, denominado "BB CPP PROJETOS", da qual é cotista exclusive, inscrito no CNPJ sob o no 17.116.243/0001-92, doravante denominado FUNDO, administrado pela BB DTVM .

$(\ldots)$

52.7 A PARCELA A da REMUNERAÇÃO a que a Concessionária faz jus por passageiro transportado, prevista no subitem 6.1.1 da Cláusula Sexta _ Da Remuneração e Pagamentos, ficará automaticamente acrescida de valor adicional de $\mathrm{R} \$ 2,00$ (dois reais) por passageiro transportado, sendo tal valor adicional doravante denominado REMUNERAÇÃO 
CONTINGENTE, nas seguintes hipóteses: i) esgotamento da Garantia Real, em face da sua eventual não recomposição mediante ressarcimento à CPP pelo PODER CONCEDENTE na forma prevista no item 52.5 desta Cláusula e da não retomada do pagamento da CONTRAPRESTAÇÃO PECUNIÁRIA pelo PODER CONCEDENTE no prazo definido no item 6.5.5 da Cláusula Sexta; ii) ocorrência de novo evento de inadimplemento do pagamento da CONTRAPRESTAÇÃO PECUNIÁRIA, a qualquer tempo, enquanto a GARANTIA REAL ainda não estiver sido recomposta, mediante ressarcimento à CPP pelo PODER CONCEDENTE na forma prevista no item 52.5 desta Cláusula.

52.7.1 A REMUNERAÇÃO CONTINGENTE será auferida pela CONCESSIONÁRIA, independentemente de qualquer anuência prévia do PODER CONCEDENTE, junto à CÂMARA DE COMPENSAÇÃO do SISTEMA DE ARRECADAÇÃO CENTRALIZADA, sendo retirada da parcela correspondente à arrecadação do sistema de transporte metroferroviário da Região Metropolitana de São Paulo, controlada pelo COMITÊ METROFERROVIÁRIO, após o cumprimento das obrigações de pagamento já contraídas com a Concessionária da Linha 4- Via Quatro, de acordo com a sistemática prevista na Cláusula Vigésima Oitava _Centralização da Arrecadação e da Percepção da Tarifa de Remuneração.

52.7.2 Aplica-se à REMUNERAÇÃO CONTINGENTE o mesmo regramento estabelecido para a TARIFA DE REMUNERAÇÃO no que diz respeito ao reajuste, previsto no item 7.1 da Cláusula Sétima - Da Remuneração e Pagamentos, sendo também a ela aplicável o mesmo mecanismo previsto para a PARCELA A da REMUNERAÇÃO quanto ao Risco de Demanda Projetada, na forma do item 20.7 da Cláusula Vigésima _ Da Mitigação e Repartição dos Riscos. 